\title{
Horse Owner Compliance to Non-Pharmaceutical Interventions During the COVID-19 Pandemic
}

\author{
Veronica Fowler ${ }^{1, *}$ and Loni Loftus ${ }^{2}$
}

1 Eco Animal Health; veronica.fowler@ecoanimalhealth.com

2 University Centre Askham Bryan, York, YO23 3FR

* Correspondence: veronica.fowler@ecoanimalhealth.com

\begin{abstract}
Simple Summary:
Compliance with non-pharmaceutical interventions such as social distancing, wearing of masks and good hygiene can have significant impact on reducing disease transmission for diseases such as COVID-19. In the UK there are more than 350,000 horse owners, keeping their horses at a variety of different, often busy settings. This, combined with horse ownership and riding being very much a social activity, naturally brings groups of people together. The purpose of this study was to identify and evaluate the compliance of horse owners with non-pharmaceutical interventions. The results indicate that compliance of horse owners with COVID-19 rules/guidance is high when rules/guidance exists. However, just under half of respondents indicated that there were no rules/guidelines on their yards indicating that there is room for an increased contribution from the horse owning community by encouraging more yards to impose control measures where they currently do not exist.
\end{abstract}

\section{Abstract:}

In December 2019, an unusual cluster of pneumonia cases were reported in Wuhan and promptly confirmed to be caused by a new virus known as severe acute respiratory syndrome coronavirus 2 (SARS-CoV-2) of which the disease it caused would be known as COVID-19. In March 2020, in the absence of any vaccines, and in response to the global spread of SARS-CoV-2 the UK implemented non-pharmaceutical intervention (NPI) measures in the form of a national lockdown to decelerate the spread. Compliance with NPIs can have significant impact on reducing disease transmission however there are currently no studies measuring compliance within the horse ownership world which naturally brings groups of people together during everyday caregiving activities. This article describes the reported horse owner compliance during the COVID-19 pandemic from March 2020 to December 2020 as deduced from 1036 respondents which completed an anonymous online survey between December $30^{\text {th }}, 2020$ and January $11^{\text {th }}, 2021$. Where rules/guidance did exist, there was good compliance with $92.76 \%$ of respondents indicating that they were following them. The most common rule/guidance implemented was social distancing, which was also the most common rule/guidance to be breached. Riding with others whilst at the yard (hacking or in an arena) and meeting up with non-household members (family and friends) when off the yard were also common rules/guidelines breached. Respondents who kept their horses at either DIY livery, or on a private yard were most likely to breach rules/regulations whereas respondents who kept their horses at full livery were least likely to breach rules/regulations. The results indicate that compliance of horse owners with COVID-19 rules/guidance is high when rules/guidance exists. However, just under half of respondents indicated that there were no rules/guidelines on their yards indicating that there is room for an increased contribution from the horse owning community by encouraging more yards to impose control measures where they currently do not exist.

Keywords: COVID-19; SARS-CoV-2; horse owner compliance; non-pharmaceutical interventions

\section{Introduction}


In December 2019, an unusual cluster of pneumonia cases were reported by the Chinese Centre for Disease Control (China CDC) in the city of Wuhan, Hubei province [1]. Sequencing of nucleic acid extracted from airway epithelial cells taken from the patients suffering from pneumonia quickly identified a novel betacoronavirus as the causal agent [2]. This betacoronavirus was subsequently named by the International Committee on Taxonomy of Viruses as severe acute respiratory syndrome coronavirus 2 (SARS-CoV-2) due to the close genetic relatedness to SARS-CoV [3] and the disease which it causes was named COVID-19.

Since its discovery, SARS-CoV-2 has spread around the globe reaching pandemic status, and by January 2021 had infected 93 million people and caused more than 2 million deaths [4].

The first confirmed case of SARS-CoV-2 diagnosed in Europe was on the $24^{\text {th }}$ January 2020 in France in a man who had recently returned from Wuhan [5] and on the 1 ${ }^{\text {st }}$ February the first two cases were reported by WHO in the United Kingdom [6].

In March 2020, the UK implemented non-pharmaceutical interventions (NPIs) control measures in the form of a national lockdown to decelerate the spread including testing, social distancing, shielding and self-isolation with the slogan "stay at home, protect the NHS, save lives". Despite easing of some restrictions in late May-June 2020 and the "downgrading" of the slogan to "stay alert, control the virus, save lives" and then to, "Hands, Face, Space" the UK has subsequently returned to further lockdowns, the first of which using a tiered approach and the most recent of which a return to national lockdown with the return of the now famous slogan "stay at home, protect the NHS, save lives".

For NPIs to have an impact on reducing disease transmission, compliance with the measures is required. Since the $23^{\text {rd }}$ of March 2020 researchers from University College London (UCL) have been studying compliance across the United Kingdom via the UK COVID-19 Social Study [7]. From more than 70,000 respondents 96\% reported to be complying with the majority of rules, whilst complete compliance with no bending of the rules was reported by $56 \%$ of respondents.

Rules that were reportedly broken included a) meeting up with more than the recommended number of people (24\% reported breaking this rule outside and $23 \%$ reported breaking this rule indoors); b) not washing hands $(45 \%)$, c) not maintaining the recommended distance from others $(8 \%)$, d) not weaning face masks $(7 \%)$ and e) not isolating when developing symptoms (13\%) [7].

In the UK there are more than 350,000 horse owners [8] keeping their horses at a variety of different settings ranging from the home to full livery. During the COVID-19 pandemic the government issued advice for pet owners and livestock keepers on looking after the welfare of their animals during the pandemic [8]. Owners were permitted to leave their home to visit and provide care for their horse (whether at livery or on private land) and were permitted to ride or walk their horse to maintain their health and welfare. Owners were instructed to follow social distancing rules, wash hands before and after contact with any animal and make a plan for the care of their horse in case of the need to selfisolate.

This article describes the reported horse owner compliance during the COVID-19 pandemic from March 2020 to December 2020.

\section{Materials and Methods}


1036 respondents were recruited online via the sharing of a link to a survey to horse specific Facebook ${ }^{\circledR}$ groups. The survey was anonymous and did not collect personal data. No inclusion or exclusion criteria were set.

The survey was designed using Survey Monkey® (San Mateo, CA, USA) and consisted of eight questions of which three had one linked sub-question. Four were closed questions with multiple choice answers and seven were open for free text answers (four primary questions and three sub-questions). The survey was live between December $30^{\text {th }}$, 2020 and January $11^{\text {th }}, 2021$. For informed consent, an accompanying paragraph was included with the link to the survey which included a brief description of the purpose of the survey, notification that the survey was anonymous, and that the data would be used for academic publication. Ethical approval was granted by the Ethics Committee of University Centre Askham Bryan, certificate number 2020/SRP/182.

Demographics: Respondents were asked which country [free text] and region they lived in [free text].

Horse information: Respondents were asked how many horses they owned [free text], what breed their horses were [free text] and on what type of yard they were kept at [home, private yard, livery DIY, livery part, livery full, or other]. Respondents who selected "other" were asked for specific details.

COVID-19 Compliance with guidelines: Respondents were asked if there were any COVID-19 rules at their yard [yes/no] and who the rules were imposed by [by you (the horses' owner)/by yard manager]. If rules existed, respondents were asked to describe what rules were present [free text], whether they were complying [yes/no] and if not, to describe what they were not doing [free text]. Respondents were then asked if they were complying to the national guidelines when not undertaking horse related activities (e.g., not at their yard) [yes/no] and if not, to describe what they were not doing [free text].

Raw data was downloaded from Survey Monkey® (San Mateo, CA, USA) into Microsoft Excel $^{\text {TM }}$ 2012. Free text answers were grouped manually into categories which best represented the response (Table 1) to allow for quantification of qualitative answers. Twenty-two categories were identified relating to rules imposed on yards either by owners or yard managers. Sixteen categories were identified relating to rules which were being breached whilst owners were on their yard. Eight categories were identified relating to national guidelines which were being breached when owners were not at their yard.

Table 1. Definition of categorization for free text responses

\begin{tabular}{|c|c|}
\hline Identified Category & Definition \\
\hline \multicolumn{2}{|c|}{ Rules/Guidance imposed by owner or yard manager } \\
\hline Social distancing & $\begin{array}{l}\text { Restrictions on distance between mem- } \\
\text { bers of different households. }\end{array}$ \\
\hline Only essential visits/visitors & Restrictions on who can visit yard. \\
\hline Visit scheduling & $\begin{array}{l}\text { Respondent required to book a time slot } \\
\text { to attend yard. }\end{array}$ \\
\hline Face mask & $\begin{array}{l}\text { Respondent and or visitor to yard ex- } \\
\text { pected to wear a face mask. }\end{array}$ \\
\hline Separate tools & $\begin{array}{l}\text { Respondent is expected to use their own } \\
\text { equipment and tack. }\end{array}$ \\
\hline Basic riding/no riding & $\begin{array}{l}\text { Riding of respondents horse was im- } \\
\text { pacted in some way. }\end{array}$ \\
\hline
\end{tabular}




\begin{tabular}{|c|c|}
\hline Cleaning tools/touchpoints & $\begin{array}{l}\text { Disinfection of shared equipment and or } \\
\text { multiple use surfaces. }\end{array}$ \\
\hline Hand cleaning & $\begin{array}{l}\text { Hand washing/sanitization required to } \\
\text { enter and/or whilst on yard. }\end{array}$ \\
\hline No owner visits & $\begin{array}{l}\text { Respondent was not allowed to visit } \\
\text { horse. Essential others permitted. }\end{array}$ \\
\hline Complete yard lockdown & $\begin{array}{l}\text { No persons except yard manager/staff } \\
\text { were permitted to enter yard. }\end{array}$ \\
\hline Gloves & $\begin{array}{l}\text { Requirement to wear gloves for at least } \\
\text { some activities on the yard. }\end{array}$ \\
\hline Isolation policy & $\begin{array}{l}\text { Respondents not permitted to attend yard } \\
\text { if displaying symptoms or if they had } \\
\text { been in contact with someone with symp- } \\
\text { toms/positive test. }\end{array}$ \\
\hline No touching of horses by strangers & $\begin{array}{l}\text { No interaction permitted with other peo- } \\
\text { ples horses. }\end{array}$ \\
\hline Yard facilities shut & Toilets/tea rooms/social rooms etc. closed. \\
\hline Bubbles & $\begin{array}{l}\text { Requirement for respondents to only in- } \\
\text { teract with members of their own bubbles. }\end{array}$ \\
\hline Track and Trace App & $\begin{array}{l}\text { Requirement to scan into yard using NHS } \\
\text { Track and Trace App. }\end{array}$ \\
\hline Windows open in inside spaces & $\begin{array}{l}\text { Requirement for windows to be open in } \\
\text { shared internal spaces. }\end{array}$ \\
\hline Foot dip & $\begin{array}{l}\text { People entering and existing the yard ex- } \\
\text { pected to dip their feet in disinfectant. }\end{array}$ \\
\hline Sitting outside & $\begin{array}{l}\text { People required to sit outside for matters } \\
\text { that require sitting. }\end{array}$ \\
\hline Temperature check & $\begin{array}{l}\text { Respondents check their temperature is } \\
\text { normal before entering the yard. }\end{array}$ \\
\hline Sign in/out & $\begin{array}{l}\text { Requirement to scan into yard using an } \\
\text { informal register. }\end{array}$ \\
\hline Negative test & $\begin{array}{l}\text { Requirement to show evidence of a nega- } \\
\text { tive test before entering the yard. }\end{array}$ \\
\hline \multicolumn{2}{|c|}{ Rules/Guidance not observed by owners when on their yard } \\
\hline Not social distancing & $\begin{array}{l}\text { Any breach to social distancing, even if } \\
\text { just once, or for horse welfare reasons. }\end{array}$ \\
\hline Owner does not feel rules are necessary & $\begin{array}{l}\text { Any reason given where rules are not fol- } \\
\text { lowed. }\end{array}$ \\
\hline Riding with others & $\begin{array}{l}\text { Respondent reports riding with others } \\
\text { outside their household either hacking or } \\
\text { in an arena. }\end{array}$ \\
\hline Still exercising horses/lessons & $\begin{array}{l}\text { Respondent reports riding and/or having } \\
\text { lessons but does not provide context (e.g. } \\
\text { does not specifically say with others from } \\
\text { outside their household) }\end{array}$ \\
\hline Going to yard in lockdown & $\begin{array}{l}\text { Respondent attending yard when they be- } \\
\text { lieve that they should remain at home. }\end{array}$ \\
\hline Not hand washing & $\begin{array}{l}\text { Respondent reports not following hand } \\
\text { washing guidelines. }\end{array}$ \\
\hline Caring for other people's horses & $\begin{array}{l}\text { Respondent reports that they have han- } \\
\text { dled/cared for other people's horses. }\end{array}$ \\
\hline Moving between tiers & $\begin{array}{l}\text { Respondent has moved between tiers ei- } \\
\text { ther to attend to their horse kept in a }\end{array}$ \\
\hline
\end{tabular}




\begin{tabular}{|c|c|}
\hline & $\begin{array}{l}\text { different tier or to take their horse to a } \\
\text { competition in a different tier. }\end{array}$ \\
\hline Not isolating when should be & $\begin{array}{l}\text { Respondent reports that they did not self- } \\
\text { isolate when they should have (e.g., re- } \\
\text { turning from holiday or whilst waiting for } \\
\text { a test result) }\end{array}$ \\
\hline Using shared equipment & $\begin{array}{l}\text { Respondent reports that they have used } \\
\text { shared equipment whether or not they } \\
\text { have disinfected it afterwards. }\end{array}$ \\
\hline Household mixing & $\begin{array}{l}\text { Respondent has mixed with different } \\
\text { households with or without observing so- } \\
\text { cial distancing in private (yard) settings. }\end{array}$ \\
\hline Not wearing gloves & $\begin{array}{l}\text { Respondent reports not wearing gloves } \\
\text { when yard guidelines are to. }\end{array}$ \\
\hline Not when welfare dictates & $\begin{array}{l}\text { Respondent will ignore all guidance if a } \\
\text { welfare situation dictates. }\end{array}$ \\
\hline \multicolumn{2}{|c|}{ Rules/Guidance not observed when owners not on their yard } \\
\hline Seeing family members & $\begin{array}{l}\text { Respondent has continued to meet up } \\
\text { with family members not in the same } \\
\text { household. }\end{array}$ \\
\hline Seeing non-family & $\begin{array}{l}\text { Respondent has continued to meet up } \\
\text { with non-family (friends) members not in } \\
\text { the same household. }\end{array}$ \\
\hline Leaving home & $\begin{array}{l}\text { Respondent has left home for non-essen- } \\
\text { tial reasons when they believe they } \\
\text { should not have. }\end{array}$ \\
\hline Not wearing a mask & $\begin{array}{l}\text { Respondent reports not wearing a mask } \\
\text { when they believe they should be. }\end{array}$ \\
\hline Not social distancing & $\begin{array}{l}\text { Respondent has not socially distanced } \\
\text { whether unavoidable or deliberately not } \\
\text { observing. }\end{array}$ \\
\hline Not following any rules/guidance & $\begin{array}{l}\text { Respondent reports that they are not ob- } \\
\text { serving any national guidance. }\end{array}$ \\
\hline Travelling abroad & $\begin{array}{l}\text { Respondent reports travelling abroad for } \\
\text { non-essential travel. }\end{array}$ \\
\hline Moving between tiers & Respondent has moved between tiers. \\
\hline
\end{tabular}

\section{Results}

\subsection{Demographics}

There were a total of 1036 responses of which 1019 were from Great Britain and Ireland, one from the Isle of Man, three from Jersey and 13 from the rest of the world (South Africa, Canada, Australia, Germany, New Zealand, Spain and USA) (Appendix A1).

\subsubsection{Horse information}

930 owners had five horses or less, 76 owners had ten horses or less, 29 owners had greater than ten horses. One participant did not answer this question.

$242(23.35 \%)$ owners kept their horses at home, 237 (22.87\%) kept their horses at a private yard, 469 (45.27\%) owners kept their horse at livery [333 on "Do it yourself" (DIY) livery, 78 on part livery and 58 on full livery] and 88 (8.49\%) owners kept their horses at "other" accommodation [Two on assisted DIY, 14 on a farm, 44 in field, three on the yard 
respondent employed at, two at retirement livery, five at a riding school, one at a restaurant and 16 on mixed settings] (Figure 1).

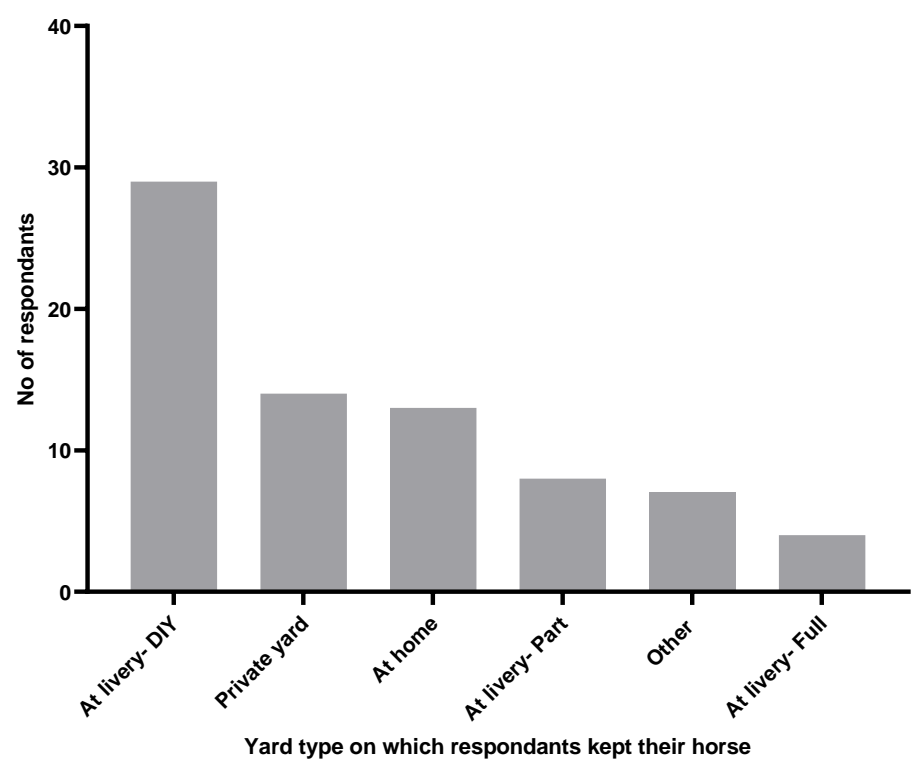

Figure 1. Yard type on which respondents' horses are kept. Other: farm, field, yard employed at, retirement livery, riding school, restaurant, and mixed settings.

\subsubsection{COVID-19 rules/guidelines on yards}

$554(53.47 \%)$ respondents reported that there were rules/guidelines where they kept their horse, of which 395 (71.29\%) were imposed by their yard owner and 159 (28.70\%) were imposed by the horse owner themselves. Three horse owners did not answer this question. For the 395 respondents who said there were rules/guidelines imposed by their yard manager, social distancing was by far the most common, followed by restricting visits to only essential visits and visit scheduling (Figure 2; Appendix B1). For the 159 respondents who said they imposed their own rules/guidelines, social distancing was by far the most common, followed by restricting visits to only essential visits and hand cleaning (Figure 3; Appendix C1).

$479(46.23 \%)$ owners reported that there were no rules where they kept their horse. 34 respondents who stated there were no rules at their yard provided a text response. 32 owners said there was no need for rules at their yard as it was sole use (private or home settings). One respondent said although their yard had no rules they spent as little time as possible at their yard and one respondent said there are no official rules, but they apply social distancing if they see the yard owner.

961 (92.76\%) owners reported that they were following rules/guidelines where they kept their horse, whilst 75 (7.23\%) owners reported that they were not following the rules/guidelines where they kept their horse. Social distancing was by far the most common rule/guideline not observed, followed by owners not following rules/guidelines because they felt under their circumstances they were not required (Figure 2; Appendix D1). The yard type with the greatest number of respondents reporting that they were not following rules/guidelines were those respondents keeping horses on DIY livery yards, followed by those keeping horses on private yards and at home (Figure 4). 
$1000(96.52 \%)$ owners reported that they were following the rules when they were not at their yard, whilst 3\% of owners reported that they were also breaching COVID rules/guidelines when not at their yard. Eight respondents did not answer this question (Figure 5; Appendix E). The 30 respondents who reported breaching rules/guidelines when not at their yard kept their horses at livery - DIY $(n=10)$, at private yards $(n=10)$, at livery - part $(n=5)$, at home $(n=1)$ and other $(n=4)$. There were no respondents who kept horses on full livery yards who reported breaking rules when not at their yard (Figure $6)$.

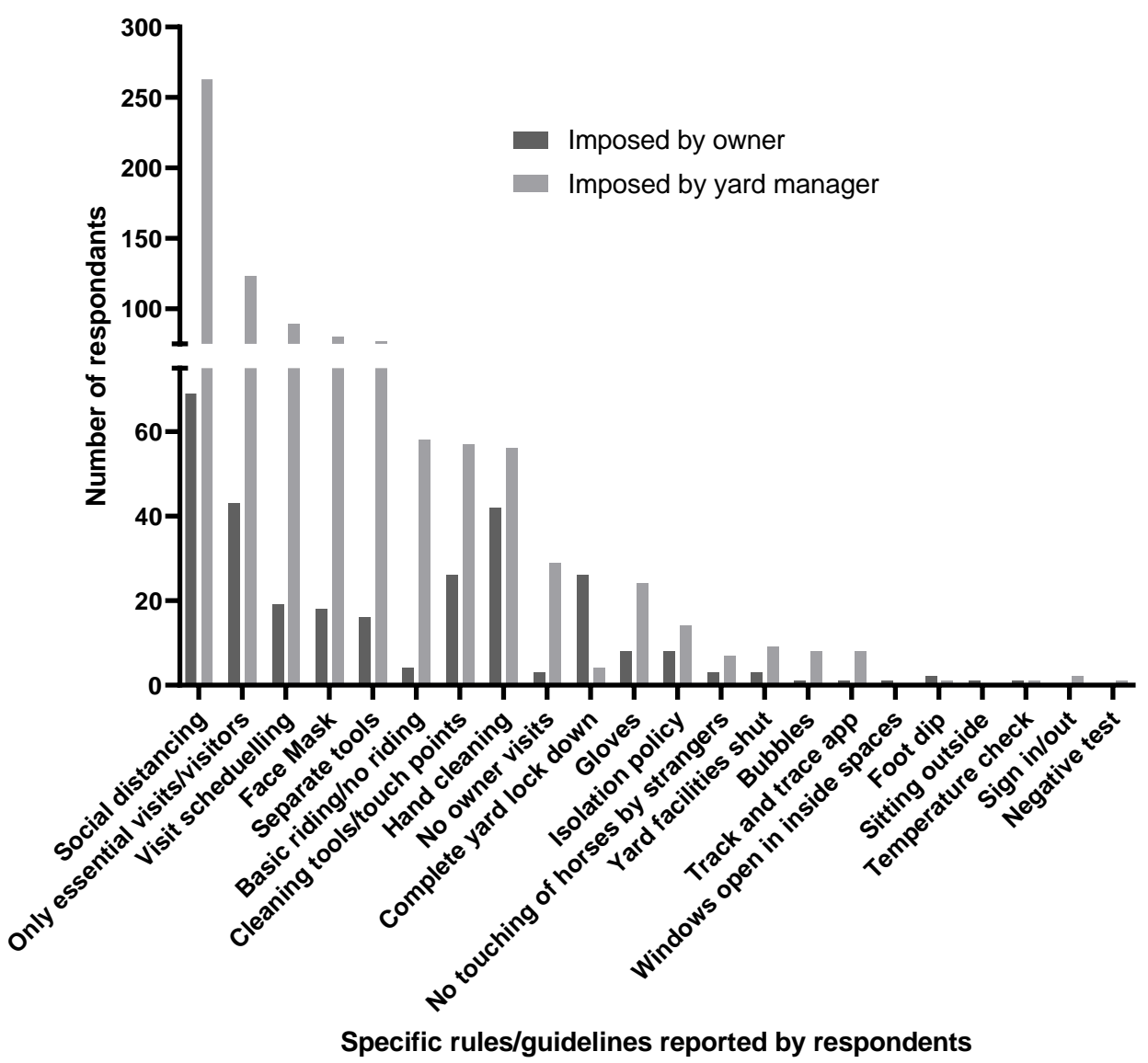

Figure 2. Specific rules/guidelines reported by respondents to be imposed by themselves or yard manager. 


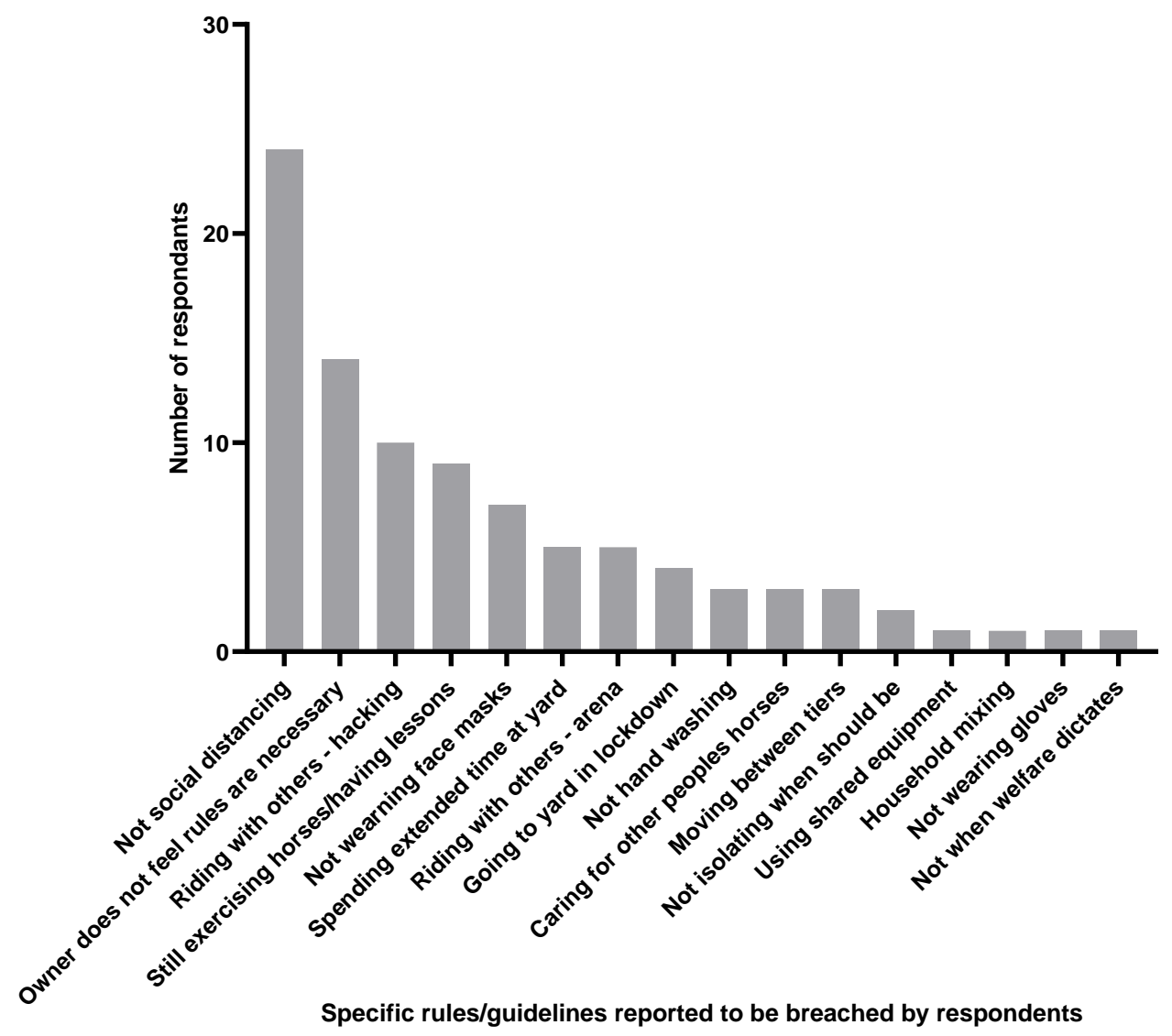

Figure 3. Specific rules/guidelines imposed on their yard reported to be breached by respondents.

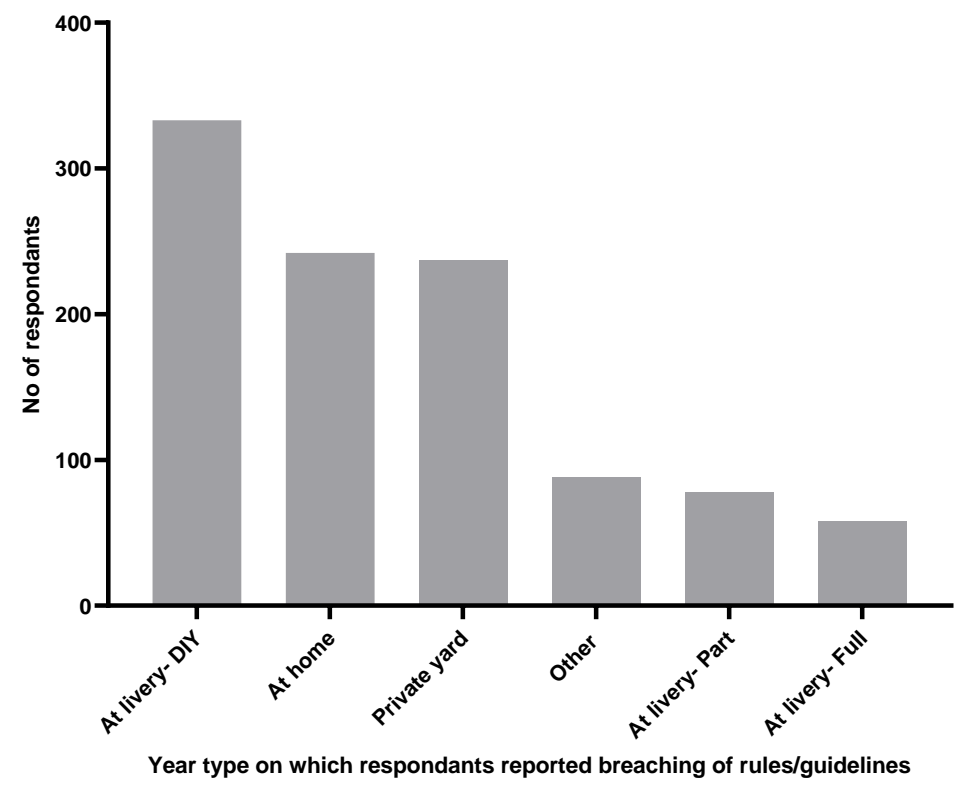

Figure 4. Location of respondents reporting breaching of rules/guidelines when on their yard categorized by yard type. Other: farm, field, yard employed at, retirement livery, riding school, restaurant and mixed settings. 


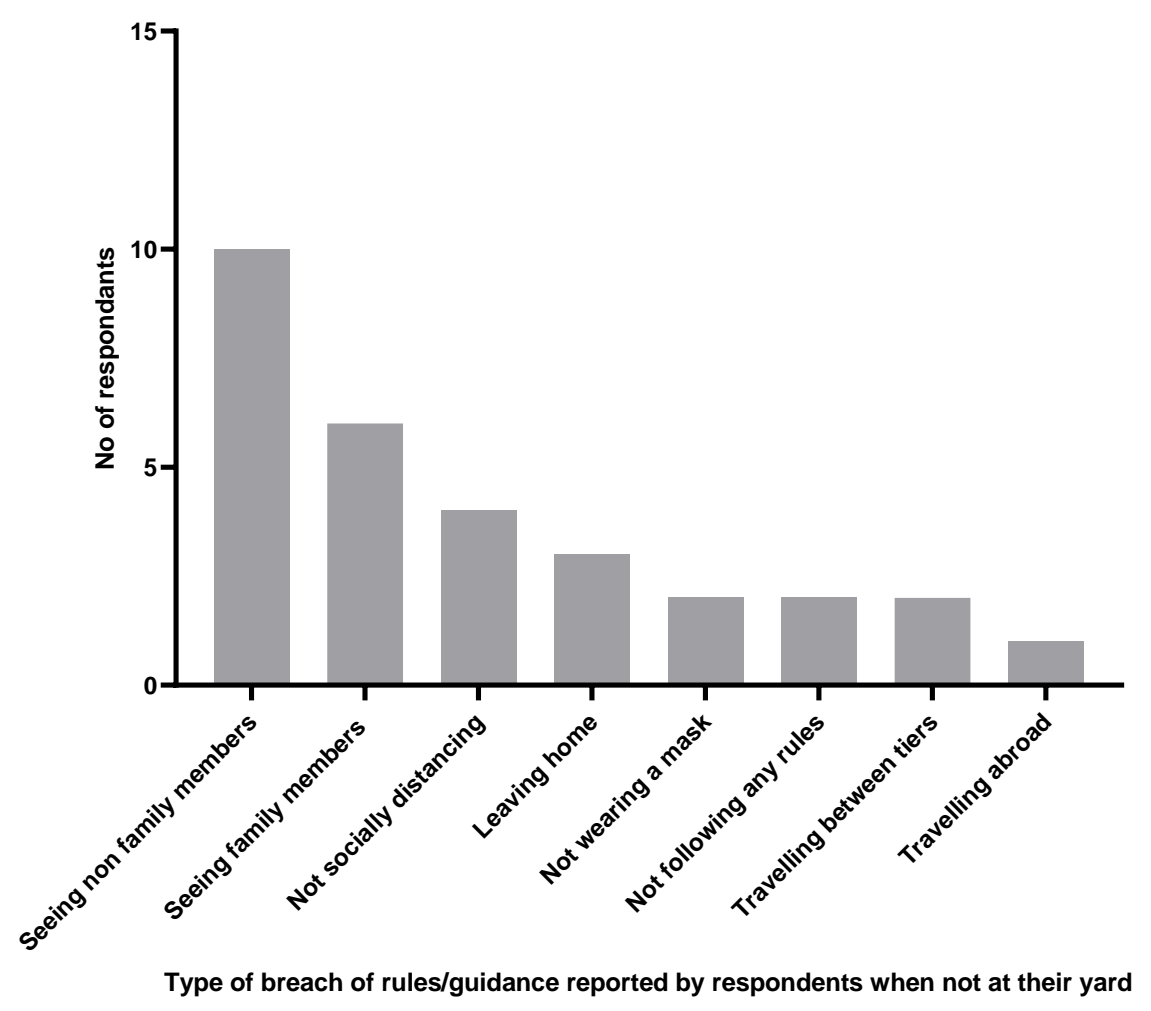

Figure 5. Type of breach of rules/guidance reported by respondents when not at their yard.

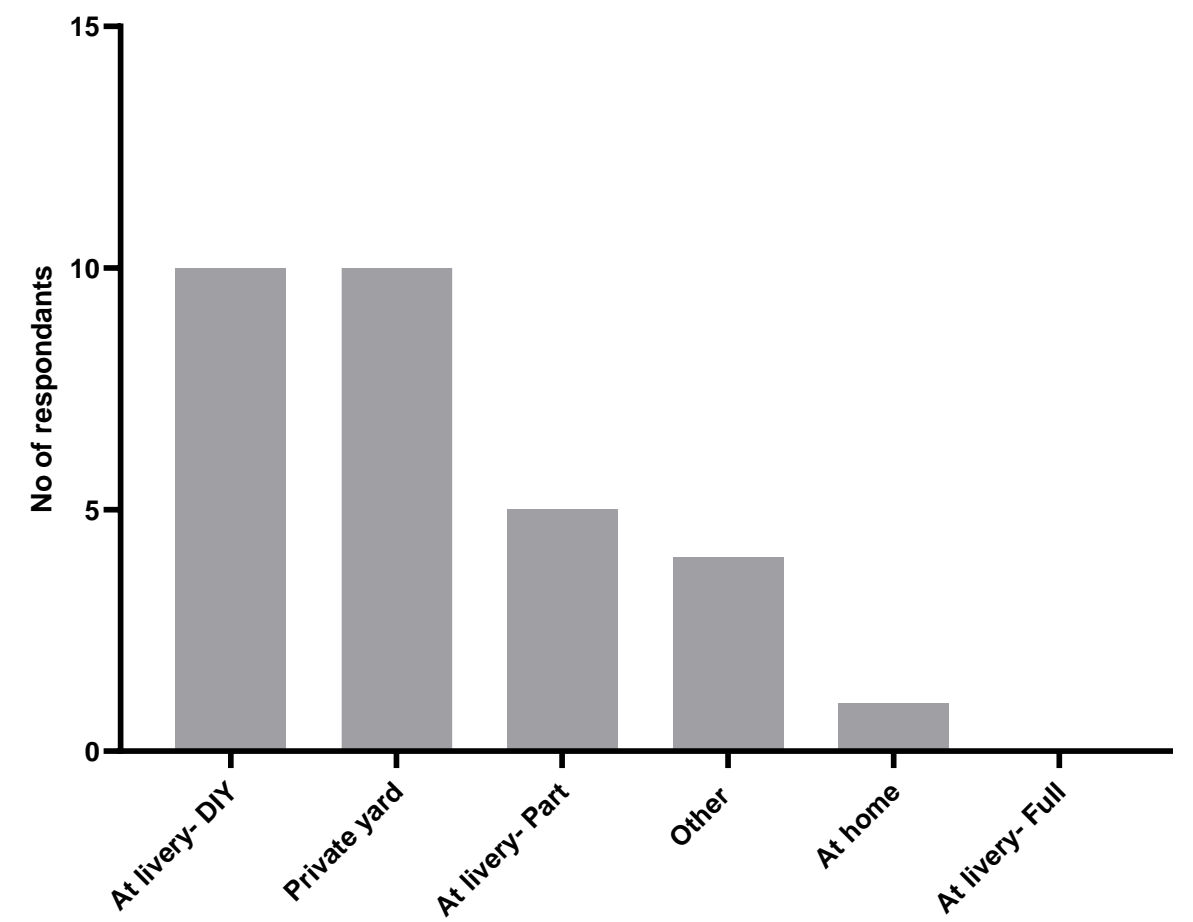

Location of where respondents reporting breaching of rules/guidelines when not at their yard kept their horses

Figure 6. Location of where respondents reporting breaching of rules/guidelines when not at their yard kept their horses. Other: farm, field, yard employed at, retirement livery, riding school, restaurant and mixed settings 


\section{Discussion}

For NPIs to have an impact on reducing disease transmission, control measures must be implemented and compliance with these rules/guidelines must be observed. This study is the first to report the compliance of horse owners to COVID-19 rules/guidance whilst attending to their horse and in general. Results from this study indicate that just over half (53.47\%) of the 1036 respondents had rules/guidance designed to specifically reduce the risk of SARS-CoV-2 transmission on their yard. Where rules/guidance did exist, there was good compliance with $92.76 \%$ of respondents indicating that they were following them which is consistent with the general compliance findings of the UK COVID-19 Social Study [7].

The most common rule/guidance implemented by both owners and yard managers was social distancing $(28.86 \%$ and $23.38 \%$ respectively), which was also the most common rule/guidance to be breached by horse owners $(25.80 \%)$ when attending to their horse. This compliance breach was greater than the general compliance findings of the UK COVID-19 Social Study [7] which reported that only $8 \%$ of people were not maintaining the recommended distance from others.

Riding with others whilst at the yard (hacking or in an arena) and meeting up with non-household members (family and friends) when off the yard were also common rules/guidelines breached (16.12\% and 53.33\% respectively). This was again consistent with the general compliance findings of the UK COVID-19 Social Study [7] which reported that $24 \%$ were meeting up outside and $23 \%$ meeting up indoors.

Lack of compliance with wearing a facemask whilst on the yard (7.52\%) was identical to the findings of the UK COVID-19 Social Study [7] (7\%); whilst lack of compliance with hand washing (3.22\%) and not isolating when required to $(2.15 \%)$ were considerably lower than those reported by UK COVID-19 Social Study [7] of 45\% and 13\% respectively [7].

Respondents who kept their horses at either DIY livery, or on a private yard were most likely to breach rules/regulations both on (38.66 and $18.66 \%$ respectively) or off yard (33.33\% and 33.33\% respectively). Respondents who kept their horses at full livery were least likely to breach rules/regulations both on $(5.33 \%)$ or off yard $(0 \%)$.

Fifteen percent of respondents in this study reported that they were simply not following rules because they believed they were unnecessary.

\section{Conclusions}

Compliance of horse owners with COVID-19 rules/guidance when on and off their yard is high when rules/guidance exists. However, there is room for an increased contribution from the horse owning community by encouraging more yards to impose control measures where they currently don't exist and to improve the conditions which would permit less breaching of social distancing.

Funding: This research received no external funding.

Institutional Review Board Statement: Ethical approval was granted by the Ethics Committee of University Centre Askham Bryan, certificate number 2020/SRP/182.

For informed consent, an accompanying paragraph was included with the link to the survey which included a brief description of the purpose of the survey and notification that the survey was anonymous, and the data would be used for academic publication.

Acknowledgments: Thanks is due to both the Facebook pages which allowed the posting of the survey link and also to the respondents of the survey which without participation, this study would not have been possible. 
Conflicts of Interest: The authors declare no conflict of interest.

\section{References}

[1] WHO. Pneumonia of unknown cause. Available at https://www.who.int/csr/don/05-january2020-pneumonia-of-unkown-cause-china/en/ 2020.

[2] Zhu N, Zhang D, Wang W, Li X, Yang B, Song J, Zhao X, Huang B, Shi W, Lu R, Niu P, Zhan F, Ma X, Wang D, Xu W, Wu G, Gao GF, Tan W; China Novel Coronavirus Investigating and Research Team. A Novel Coronavirus from Patients with Pneumonia in China, 2019. N Engl J Med. 2020 Feb 20;382(8):727-733. doi: 10.1056/NEJMoa2001017. Epub 2020 Jan 24. PMID: 31978945; PMCID: PMC7092803.

[3] Gorbalenya A.E, Baker S.C, Baric R.S, Groot R.J.D, Gulyaeva A.A, Haagmans B.L, et al. The species and its viruses - a statement of the Coronavirus Study Group. Biorxiv (Cold Spring Harb Lab 2020:1-15. Doi: 10.1101/2020.02.07.937862.

[4] World Health Organisation situation report 19th January 2021. Weekly epidemiological update - 19 January 2021 (who.int)

[5] World Health Organisation Situation Report -5 25th January 2020. 20200125-sitrep-5-2019ncov.pdf (who.int)

[6] World Health Organisation Situation Report -12 $1^{\text {st }}$ February 2020 20200201-sitrep-12ncov.pdf (who.int)

[7] Covid-19 Social Study Results release 28. 13 $13^{\text {th }}$ January 2021. 3d9db5 bf013154aed5484b970c0cf84ff109e9.pdf (filesusr.com)

[8] Coronavirus (COVID-19): advice for people in England with animals - GOV.UK (www.gov.uk)

[9] British Equestrian Trade Association BETA. British National Equestrian Survey 2019. Available online: https://www.beta-uk.org/pages/news-amp-events/news/beta-national-equestrian-survey2019-reveals-an-increase-in-riding.php (accessed on 26 January 2021).

Appendix A1. Detailed breakdown of the region from which respondents were from

\begin{tabular}{cc}
\hline Region & Number of participants \\
\hline Aberdeenshire & 4 \\
\hline Angus & 2 \\
\hline Armagh & 1 \\
\hline Ayrshire & 7 \\
\hline Bedfordshire & 5 \\
\hline Berkshire & 21 \\
\hline Borders & 2 \\
\hline Bridgend & 3 \\
\hline Buckinghamshire & 11 \\
\hline Cambridgeshire & 12 \\
\hline Carmarthanshire & 11 \\
\hline Ceredigion & 6 \\
\hline Cheshire & 15 \\
\hline Clackmannanshire & 1 \\
\hline Cleveland & 1 \\
\hline Co. Clare & 2 \\
\hline Co. Down & 2 \\
\hline Cornwall & 15 \\
\hline Cotswolds & 1 \\
\hline County Durham & 5 \\
\hline Cumbria & 14 \\
\hline
\end{tabular}




\begin{tabular}{|c|c|}
\hline Darlington - County Durham & 1 \\
\hline Denbighshire & 2 \\
\hline Derbyshire & 22 \\
\hline Devon & 31 \\
\hline Dorset & 27 \\
\hline Douglas & 1 \\
\hline Dumfries and Galloway & 1 \\
\hline Dumfriesshire & 1 \\
\hline Dunbartonshire & 3 \\
\hline East Anglia & 1 \\
\hline East Lothian & 2 \\
\hline East Midlands & 7 \\
\hline East of England & 1 \\
\hline East Riding of Yorkshire & 3 \\
\hline England & 4 \\
\hline Essex & 29 \\
\hline Fermanagh & 1 \\
\hline Fife & 8 \\
\hline Flintshire & 3 \\
\hline Galicia & 1 \\
\hline Galway & 1 \\
\hline Glamorgan & 3 \\
\hline Glasgow & 3 \\
\hline Gloucestershire & 9 \\
\hline Grampian & 1 \\
\hline Gwent & 1 \\
\hline Gwynedd & 7 \\
\hline Hampshire & 94 \\
\hline Herefordshire & 16 \\
\hline Highlands & 2 \\
\hline Isle of Man & 1 \\
\hline Isle of Wight & 1 \\
\hline Jersey & 3 \\
\hline Kent & 22 \\
\hline Kilkenny & 1 \\
\hline Lanarkshire & 2 \\
\hline Lancashire & 23 \\
\hline Leicestershire & 10 \\
\hline Leinster & 1 \\
\hline Lincolnshire & 24 \\
\hline London & 4 \\
\hline Lothian & 1 \\
\hline Manchester & 8 \\
\hline Meath & 1 \\
\hline Merseyside & 2 \\
\hline Merthyr Tydfil & 1 \\
\hline Mid Glamorgan & 2 \\
\hline Mid wales & 1 \\
\hline Midlands & 5 \\
\hline Midlothian & 6 \\
\hline
\end{tabular}




\begin{tabular}{|c|c|}
\hline $\mathrm{N}$ Ireland & 1 \\
\hline Neath & 3 \\
\hline New Forest & 6 \\
\hline Newport & 1 \\
\hline Norfolk & 19 \\
\hline North East England & 12 \\
\hline North England & 3 \\
\hline North Lincolnshire & 5 \\
\hline North Nottinghamshire & 1 \\
\hline North of Dublin & 1 \\
\hline North Somerset & 7 \\
\hline North Wales & 1 \\
\hline North West England & 23 \\
\hline Northamptonshire & 14 \\
\hline Northumberland & 8 \\
\hline Nottinghamshire & 24 \\
\hline Orkney & 2 \\
\hline Oxfordshire & 9 \\
\hline Peak District & 1 \\
\hline Pembrokeshire & 8 \\
\hline Perthshire & 2 \\
\hline Powys & 4 \\
\hline Redcar and Cleveland & 1 \\
\hline Rhondda cynon Taff & 2 \\
\hline Ross-shire & 1 \\
\hline Rutland & 1 \\
\hline Scotland & 5 \\
\hline Shropshire & 11 \\
\hline Somerset & 18 \\
\hline Somersey & 1 \\
\hline South East England & 19 \\
\hline South England & 4 \\
\hline South Wales & 3 \\
\hline South West England & 11 \\
\hline Southtyneside & 1 \\
\hline Staffordshire & 18 \\
\hline Stirlingshire & 4 \\
\hline Suffolk & 20 \\
\hline Surrey & 16 \\
\hline Sussex & 26 \\
\hline Swansea & 1 \\
\hline Tameside & 1 \\
\hline Tees valley combined authority & 1 \\
\hline Teesside & 1 \\
\hline Tipperary & 1 \\
\hline Vale of Glamorgan & 3 \\
\hline Wales & 10 \\
\hline Warwickshire & 10 \\
\hline Waterford & 1 \\
\hline West Berkshire & 3 \\
\hline
\end{tabular}




\begin{tabular}{cc}
\hline West Midlands & 11 \\
\hline Western Isles & 1 \\
\hline Wigtownshire & 1 \\
\hline Wiltshire & 22 \\
\hline Wirral & 2 \\
\hline Worcestershire & 16 \\
\hline Wrexham & 5 \\
\hline Yorkshire & 69 \\
\hline Yorktown & 1 \\
\hline Rest of the world & 2 \\
\hline Canada & 1 \\
\hline Australia & 1 \\
\hline New Zealand & 1 \\
\hline North Germany & 1 \\
\hline South Africa & 1 \\
\hline Spain & 6 \\
\hline USA &
\end{tabular}

Appendix B1: Details of the rules "imposed by yard manager" at respondent yards and categorization of the answer

\begin{tabular}{|c|c|}
\hline Respondent answer & Categorisation of answer \\
\hline $\begin{array}{l}\text { Max } 2 \text { people on yard. Hand washing. } \\
\text { Max } 1.5 \text { hours on yard. No socialising. } \\
\text { Masks to be worn. No higher risk ac- } \\
\text { tivities eg jumping }\end{array}$ & $\begin{array}{l}\text { Social distancing; } \\
\text { Hand cleaning; } \\
\text { Face masks; } \\
\text { Basic riding/no riding }\end{array}$ \\
\hline $\begin{array}{l}\text { No visitors. Gloves to be worn. Maintain } \\
\text { social distance. }\end{array}$ & $\begin{array}{l}\text { Only essential visits/visitors; } \\
\text { Gloves; } \\
\text { Social distancing }\end{array}$ \\
\hline $\begin{array}{l}\text { At moment it is just social distancing, } \\
\text { hand washing/gel regularly. But in } \\
\text { march lockdown i only had access to } \\
\text { horse at full livery if 'I deemed it essen- } \\
\text { tial to see the horse'. This was limited } \\
\text { to a } 1 \text { hour time slot allocated by yard } \\
\text { owner at either } 12-1 \text { or } 1-2 \text {, only } 1 \\
\text { owner allowed at a time This was } \\
\text { horrific, detrimental to my mental } \\
\text { health \& detrimental to my horses wel- } \\
\text { fare. }\end{array}$ & $\begin{array}{l}\text { Social distancing; } \\
\text { Hand cleaning; } \\
\text { Only essential visits/visitors; } \\
\text { Visit scheduling }\end{array}$ \\
\hline $\begin{array}{l}1 \text { person into hay barn and other com- } \\
\text { munal spaces at a time. Keep distance } \\
(2 \mathrm{~m}) \text {. Don't hang around any longer }\end{array}$ & $\begin{array}{l}\text { Social distancing; } \\
\text { Only essential visits/visitors }\end{array}$ \\
\hline
\end{tabular}




\begin{tabular}{|c|c|}
\hline $\begin{array}{l}\text { than needed. } 1 \text { person per horse unless } \\
\text { it's a child. }\end{array}$ & \\
\hline $\begin{array}{l}\text { Rota limiting numbers of liveries on the } \\
\text { yard at any time. Hand sanitizer availa- } \\
\text { ble }\end{array}$ & $\begin{array}{l}\text { Visit scheduling; } \\
\text { Hand cleaning }\end{array}$ \\
\hline $\begin{array}{l}\text { Wear gloves, reduce number of people } \\
\text { on yard }\end{array}$ & $\begin{array}{l}\text { Gloves; } \\
\text { Social distancing }\end{array}$ \\
\hline $\begin{array}{l}\text { All those whose horses were on livery } \\
\text { were not to attend the yard at all. DIY } \\
\text { owners had set times to be there which } \\
\text { were staggered to ensure there were as } \\
\text { few people as possible on the yard at } \\
\text { one time and in different parts of the } \\
\text { yard. One way system established to } \\
\text { avoid crossing paths. } 1 \text { person in the } \\
\text { feed room at a time. Use only your own } \\
\text { equipment. Always keeping at least } \\
2 \text { metres apart. Lots of automatic } \\
\text { hand sanitisers. }\end{array}$ & $\begin{array}{l}\text { No owner visits; } \\
\text { Visit scheduling; } \\
\text { Social distancing; } \\
\text { Separate tools; } \\
\text { Hand cleaning }\end{array}$ \\
\hline $\begin{array}{l}\text { No visitors. No tool sharing. Hand wash- } \\
\text { ing. }\end{array}$ & $\begin{array}{l}\text { Only essential visits/visitors; } \\
\text { Separate tools; } \\
\text { Hand cleaning }\end{array}$ \\
\hline $\begin{array}{l}\text { I am personally only allowed to access } \\
\text { the yard for feed, any grooming or far- } \\
\text { rier etc must be done at the field to } \\
\text { keep number of people on the yard to a } \\
\text { minimum. Other people with horses } \\
\text { in retirement have been asked to do } \\
\text { the same, but most don't go daily like } \\
\text { myself. }\end{array}$ & $\begin{array}{l}\text { Social distancing; } \\
\text { Only essential visits/visitors; }\end{array}$ \\
\hline $\begin{array}{l}\text { Time slots and } 1 \text { person in tack room at } \\
\text { a time. Disinfect everything after use }\end{array}$ & $\begin{array}{l}\text { Visit scheduling; } \\
\text { Social distancing; } \\
\text { Disinfection of touchpoints }\end{array}$ \\
\hline Time slots & Visit scheduling; \\
\hline \multirow[t]{2}{*}{$\begin{array}{l}\text { Keep socially distanced. Don't use other } \\
\text { people's things. Use hand gel or wash } \\
\text { hands when using shared areas like toi- } \\
\text { let and kitchen. Only } 1 \text { person in tack } \\
\text { room at a time. }\end{array}$} & $\begin{array}{l}\text { Social distancing; } \\
\text { Separate tools; } \\
\text { Hand cleaning }\end{array}$ \\
\hline & No details \\
\hline
\end{tabular}




\begin{tabular}{|c|c|}
\hline $\begin{array}{l}\text { Only owners allowed on yard - no shar- } \\
\text { ers and to use own tools and keep dis- } \\
\text { tanced from everyone. }\end{array}$ & $\begin{array}{l}\text { Only essential visits/visitors; } \\
\text { Separate tools; } \\
\text { Social distancing }\end{array}$ \\
\hline $\begin{array}{l}\text { No Groups of people on Yard. Maintain } \\
\text { Social Distancing. Wash hands on arrival } \\
\text { Max one person in small areas - } \\
\text { tack/feed rooms }\end{array}$ & $\begin{array}{l}\text { Social distancing; } \\
\text { Hand cleaning }\end{array}$ \\
\hline $\begin{array}{l}\text { Distance. No borrowing of tools. No so- } \\
\text { cial gatherings. One livery per private } \\
\text { lesson. }\end{array}$ & $\begin{array}{l}\text { Social distancing; } \\
\text { Separate tools; }\end{array}$ \\
\hline $\begin{array}{l}\text { Masks indoors, social distancing and } \\
\text { stagger visit times. }\end{array}$ & $\begin{array}{l}\text { Social distancing; } \\
\text { Face mask; } \\
\text { Visit scheduling }\end{array}$ \\
\hline $\begin{array}{l}\text { Social distancing must be adhered to at } \\
\text { all times. }\end{array}$ & Social distancing \\
\hline $\begin{array}{l}\text { Just sensible. Keep your distance. Don't } \\
\text { use other people's tools. }\end{array}$ & $\begin{array}{l}\text { Social distancing; } \\
\text { Separate tools }\end{array}$ \\
\hline $\begin{array}{l}\text { Time slots to avoid too many people at } \\
\text { once. Masks to be worn in any enclosed } \\
\text { area like feed room. Only } 2 \text { people al- } \\
\text { lowed to ride out together at once (on- } \\
\text { site backing). No riding off the prem- } \\
\text { ises. Sanitise hands before touching } \\
\text { gates/keypads. }\end{array}$ & $\begin{array}{l}\text { Visit scheduling; } \\
\text { Face mask; } \\
\text { Basic riding/no riding } \\
\text { Hand cleaning }\end{array}$ \\
\hline $\begin{array}{l}\text { Time slots for riding to minimise over- } \\
\text { lap. Masks when not riding. Hand } \\
\text { sanitizer provided. Only } 1 \text { person in tack } \\
\text { room at once. }\end{array}$ & $\begin{array}{l}\text { Visit scheduling; } \\
\text { Face mask; } \\
\text { Hand cleaning; } \\
\text { Social distancing } \\
\end{array}$ \\
\hline $\begin{array}{l}\text { Daily visit for two hours at designated } \\
\text { time so as few owners there at once as } \\
\text { possible. Hacking allowed two together } \\
\text { only. }\end{array}$ & $\begin{array}{l}\text { Visit scheduling; } \\
\text { Basic riding/no riding }\end{array}$ \\
\hline $\begin{array}{l}\text { Sanitising and staggered times, only rid- } \\
\text { ing with } 1 \text { other. }\end{array}$ & $\begin{array}{l}\text { Hand cleaning; } \\
\text { Visit scheduling; } \\
\text { Basic riding/no riding } \\
\end{array}$ \\
\hline $\begin{array}{l}\text { It's a pony club riding school we have to } \\
\text { come alone not bring anyone else un- } \\
\text { less one child that rides, Keep } 2 \text { meter } \\
\text { rule at all times, use our own equip- } \\
\text { ment i.e. buckets, Barrow and tools. } \\
\text { We have to wear gloves at all times also } \\
\text { not touch other horses etc. }\end{array}$ & $\begin{array}{l}\text { Only essential visits/visitors; } \\
\text { Social distancing; } \\
\text { Separate tools; } \\
\text { Gloves; } \\
\text { No touching of horses by strangers }\end{array}$ \\
\hline
\end{tabular}




\begin{tabular}{|c|c|}
\hline 2 meter distance rule & Social distancing \\
\hline Sanitising. Social distance & $\begin{array}{l}\text { Social distancing; } \\
\text { Hand cleaning }\end{array}$ \\
\hline Keeping to own equipment & Separate tools \\
\hline $\begin{array}{l}\text { We have our own tools, are not allowed } \\
\text { to handle other people's horses, not al- } \\
\text { lowed to have more than } 1 \text { person who } \\
\text { inn the feed or tack room at a time. }\end{array}$ & $\begin{array}{l}\text { Separate tools; } \\
\text { No touching of horses by strangers; } \\
\text { Social distancing }\end{array}$ \\
\hline $\begin{array}{l}\text { Liveries were put on a timetable for at- } \\
\text { tending the yard. Only the owner al- } \\
\text { lowed to visit. No riding off the yard. } \\
\text { Hand sanitizer provided }\end{array}$ & $\begin{array}{l}\text { Visit scheduling; } \\
\text { Only essential visits/visitors; } \\
\text { Basic riding/no riding; } \\
\text { Hand cleaning }\end{array}$ \\
\hline Keep distance and sanitise & $\begin{array}{l}\text { Social distancing; } \\
\text { Hand cleaning }\end{array}$ \\
\hline $\begin{array}{l}\text { Limited people in the office. Sanitizer } \\
\text { for hands and tack. Social distancing }\end{array}$ & $\begin{array}{l}\text { Social distancing; } \\
\text { Hand cleaning }\end{array}$ \\
\hline $\begin{array}{l}\text { A maximum of } 2 \mathrm{hrs} \text { at the yard unless } \\
\text { good reason to be there longer }\end{array}$ & Visit scheduling \\
\hline $\begin{array}{l}\text { We have a rota for each barn to ensure } \\
\text { everyone can go and sort out their } \\
\text { horses/exercise them during a time } \\
\text { window that suits them, while ensuring } \\
\text { there's only two people in each barn at } \\
\text { any given time. }\end{array}$ & $\begin{array}{l}\text { Visit scheduling; } \\
\text { Social distancing }\end{array}$ \\
\hline $\begin{array}{l}\text { Wash hands (anti bac soap provided). } \\
\text { Wipe down surfaces (e.g. tap) after use. } \\
\text { Do not share mucking out tools. Yard is } \\
\text { outside and small so initially we had } \\
\text { time slot allocations. }\end{array}$ & $\begin{array}{l}\text { Hand cleaning; } \\
\text { Disinfection of touchpoints; } \\
\text { Separate tools; } \\
\text { Visit scheduling }\end{array}$ \\
\hline $\begin{array}{l}\text { Keep } 2 \mathrm{~m} \text { distance. Sanitise hands. Don't } \\
\text { bring visitors to the yard. }\end{array}$ & $\begin{array}{l}\text { Social distancing; } \\
\text { Hand cleaning; } \\
\text { Only essential visits/visitors }\end{array}$ \\
\hline $\begin{array}{l}\text { Distance. Masks. Hand sanitiser. Limit } \\
\text { visits. No mixing in other barns. }\end{array}$ & $\begin{array}{l}\text { Social distancing; } \\
\text { Hand cleaning; } \\
\text { Only essential visits/visitors }\end{array}$ \\
\hline $\begin{array}{l}\text { Wear mask when in barn, keep your } \\
\text { distance, only use your own equipment. } \\
\text { Stagger times when at the yard. }\end{array}$ & $\begin{array}{l}\text { Face mask; } \\
\text { Social distancing; } \\
\text { Separate tools; } \\
\text { Visit scheduling }\end{array}$ \\
\hline $\begin{array}{l}\text { Owners only, social distancing, no trav- } \\
\text { elling outside local area. }\end{array}$ & $\begin{array}{l}\text { Only essential visits/visitors; } \\
\text { Social distancing; } \\
\text { Basic riding/no riding }\end{array}$ \\
\hline
\end{tabular}




\begin{tabular}{|c|c|}
\hline $\begin{array}{l}\text { Don't gather in groups. Don't go in } \\
\text { other peoples barns. Only use your own } \\
\text { equipment. }\end{array}$ & $\begin{array}{l}\text { Social distancing; } \\
\text { Separate tools }\end{array}$ \\
\hline Social distancing. Hand washing. & $\begin{array}{l}\text { Social distancing; } \\
\text { Hand cleaning }\end{array}$ \\
\hline $\begin{array}{l}\text { Only one person in the tack room at a } \\
\text { time. Sanitise hands on arrival/depar- } \\
\text { ture and throughout the duration of the } \\
\text { visit. Only the number of people al- } \\
\text { lowed in guidelines allowed in the } \\
\text { school (rule of 6, same household or } \\
\text { one other person). Social distancing. }\end{array}$ & $\begin{array}{l}\text { Social distancing; } \\
\text { Hand cleaning }\end{array}$ \\
\hline $\begin{array}{l}\text { Attend by time arrangement only, own } \\
\text { tack to be kept at home and brought in, } \\
\text { any yard equipment used to be cleaned } \\
\text { before leaving (anti viral wipes provided } \\
\text { by yard owner). }\end{array}$ & $\begin{array}{l}\text { Visit scheduling; } \\
\text { Separate tools; } \\
\text { Disinfection of touchpoints }\end{array}$ \\
\hline $\begin{array}{l}\text { Keep distance, no visitors, allowed to } \\
\text { ride as only me and yard owner on the } \\
\text { yard. }\end{array}$ & $\begin{array}{l}\text { Social distancing; } \\
\text { Only essential visits/visitors; } \\
\text { Basic riding/no riding }\end{array}$ \\
\hline $\begin{array}{l}\text { Keep social distance, try to stagger visit } \\
\text { times. }\end{array}$ & $\begin{array}{l}\text { Social distancing; } \\
\text { Visit scheduling }\end{array}$ \\
\hline $\begin{array}{l}\text { Reduced amount of visits and duration } \\
\text { of visit allowed during the day }\end{array}$ & Only essential visits/visitors \\
\hline $\begin{array}{l}\text { Washing down surfaces with disinfect- } \\
\text { ant after touching, hand washing, social } \\
\text { distancing, etc }\end{array}$ & $\begin{array}{l}\text { Disinfection of touchpoints; } \\
\text { Social distancing; } \\
\text { Hand cleaning }\end{array}$ \\
\hline $\begin{array}{l}\text { Track and trace scan. Hand sanitizer sta- } \\
\text { tions. Mask waring enforced }\end{array}$ & $\begin{array}{l}\text { Track and Trace App; } \\
\text { Hand cleaning; } \\
\text { Face mask }\end{array}$ \\
\hline $\begin{array}{l}\text { Mask at all times. Hand sanitiser at en- } \\
\text { try \& exit. No sharing of equipment. No } \\
\text { sharing of tools. } 2 \text { metre distance from } \\
\text { other people. Only ride on the arena. } \\
\text { No visitors on yard, except vet or far- } \\
\text { rier. }\end{array}$ & $\begin{array}{l}\text { Face mask; } \\
\text { Hand cleaning; } \\
\text { Separate tools; } \\
\text { Social distancing; } \\
\text { Basic riding/no riding; } \\
\text { Only essential visits/visitors }\end{array}$ \\
\hline $\begin{array}{l}\text { Sanitise hands before coming on the } \\
\text { yard. Don't touch any tools unless } \\
\text { they are yours. Don't spend more } \\
\text { time at the yard than you need to. So- } \\
\text { cial distance where you can. }\end{array}$ & $\begin{array}{l}\text { Hand cleaning; } \\
\text { Separate tools; } \\
\text { Social distancing; } \\
\text { Basic riding/no riding; } \\
\text { Only essential visits/visitors }\end{array}$ \\
\hline
\end{tabular}




\begin{tabular}{|c|c|}
\hline $\begin{array}{l}2 \text { people on yard at same time during } \\
\text { lockdown. Then rule of } 6 \text {. Back to } 2 \\
\text { under tier } 4 \text {. Sanitise hands on arri- } \\
\text { val. Sanitise all handles and switches on } \\
\text { departure. Use own mucking out kit } \\
\text { only. }\end{array}$ & $\begin{array}{l}\text { Visit scheduling; } \\
\text { Social distancing; } \\
\text { Cleaning hands; } \\
\text { Separate tools; } \\
\text { Disinfection of touch points }\end{array}$ \\
\hline Social distancing & Social distancing \\
\hline $\begin{array}{l}\text { Has depended on time, in 1st lockdown } \\
\text { not allowed in yard. All horses turned } \\
\text { out and roughed off. Since in tiers and } \\
\text { national lockdown, allowed to come to } \\
\text { exercise/groom etc but must spray } \\
\text { down anything touched with disinfect- } \\
\text { ant. No socialising, riding out only in } \\
\text { group of } 2 \text { or } 6 \text { according to tier rules. } \\
\text { No access to usual facilities etc tea- } \\
\text { room. }\end{array}$ & $\begin{array}{l}\text { No owner visits; } \\
\text { Complete yard lockdown; } \\
\text { Only essential visits/visitors; } \\
\text { Disinfection of touch points; } \\
\text { Social distancing; } \\
\text { Yard facilities shut }\end{array}$ \\
\hline Sanitisation social distancing & $\begin{array}{l}\text { Social distancing; } \\
\text { Hand cleaning }\end{array}$ \\
\hline $\begin{array}{l}\text { During full lock down and also now in } \\
\text { tier } 4, \text { I cannot see my horse. My friend } \\
\text { is taking care of him as she does not } \\
\text { want visits to her home. }\end{array}$ & $\begin{array}{l}\text { No owner visits; } \\
\text { Complete yard lockdown }\end{array}$ \\
\hline $\begin{array}{l}\text { Designated times to be there. Track and } \\
\text { trace app }\end{array}$ & $\begin{array}{l}\text { Visit scheduling; } \\
\text { Track and trace app }\end{array}$ \\
\hline $\begin{array}{l}\text { Masks inside, wash hands, no riding ex- } \\
\text { cept in pairs. }\end{array}$ & $\begin{array}{l}\text { Face masks; } \\
\text { Hand cleaning; } \\
\text { Basic riding/no riding }\end{array}$ \\
\hline \multirow[t]{2}{*}{ Keep 2 meters apart. } & Social distancing \\
\hline & No details \\
\hline $\begin{array}{l}\text { Milton spray all tools and wheelbarrows } \\
\text { once touched. Ride in a pair, no more. } \\
\text { Distance whilst in the yard and the } \\
\text { kitchen area is shut. }\end{array}$ & $\begin{array}{l}\text { Disinfection of touchpoints; } \\
\text { Basic riding/no riding } \\
\text { Social distancing; } \\
\text { Yard facilities shut }\end{array}$ \\
\hline One household in office at one time & $\begin{array}{l}\text { Social distancing; } \\
\text { Bubbles }\end{array}$ \\
\hline $\begin{array}{l}\text { No social areas open. No use of other } \\
\text { tools or belongings. No more than } 2 \\
\text { in the open hay barn. Only one at a } \\
\text { time in the school. Only hacking with } \\
\text { people in your bubble. No visits from }\end{array}$ & $\begin{array}{l}\text { Social distancing; } \\
\text { Visit scheduling; } \\
\text { Separate tools; } \\
\text { Basic riding/no riding; } \\
\text { Bubble; } \\
\text { Only essential visits/visitors }\end{array}$ \\
\hline
\end{tabular}




\begin{tabular}{|c|c|}
\hline $\begin{array}{l}\text { friends or family (primary caregivers } \\
\text { only). }\end{array}$ & \\
\hline $\begin{array}{l}\text { Social distance. Time slots through first } \\
\text { lockdown. Wash hands regularly }\end{array}$ & $\begin{array}{l}\text { Social distancing; } \\
\text { Visit scheduling; } \\
\text { Hand cleaning }\end{array}$ \\
\hline Times to go/ hygiene/social distancing & $\begin{array}{l}\text { Visit scheduling; } \\
\text { Hand cleaning; } \\
\text { Social distancing }\end{array}$ \\
\hline $\begin{array}{l}\text { Time slots during lockdown. Hacking in } \\
\text { pairs only. Wash hands on arrival and } \\
\text { departure. Only one person in tack } \\
\text { room at a time. }\end{array}$ & $\begin{array}{l}\text { Visit scheduling; } \\
\text { Basic riding/no riding; } \\
\text { Social distancing; } \\
\text { Hand cleaning; }\end{array}$ \\
\hline $\begin{array}{l}\text { Time slots. Stay } 2 \text { meters apart. Get } \\
\text { horses sorted then go, not to hang } \\
\text { around. }\end{array}$ & $\begin{array}{l}\text { Visit scheduling; } \\
\text { Social distancing; } \\
\text { Only essential visits/visitors }\end{array}$ \\
\hline $\begin{array}{l}\text { Hand washing, sanitizing of common } \\
\text { surfaces, no sharing of tools, wear } \\
\text { gloves, frequent yard at different times } \\
\text { so not too many people together, social } \\
\text { distancing when together. }\end{array}$ & $\begin{array}{l}\text { Hand cleaning; } \\
\text { Disinfection of touchpoints; } \\
\text { Separate tools; } \\
\text { Gloves: } \\
\text { Visit scheduling; } \\
\text { Social distancing }\end{array}$ \\
\hline Social distance, wash hands. & $\begin{array}{l}\text { Social distancing; } \\
\text { Hand cleaning }\end{array}$ \\
\hline $\begin{array}{l}\text { Keep a distance of } 2 \text { meters. Wipe } \\
\text { down and disinfect any equipment used } \\
\text { by you or any other liveries. }\end{array}$ & $\begin{array}{l}\text { Social distancing; } \\
\text { Disinfection of touchpoints }\end{array}$ \\
\hline $\begin{array}{l}\text { Staggered times to minimise number of } \\
\text { people on the yard at the same time. } \\
\text { Reduce amount of equipment shared } \\
\text { by buying your own. Wear gloves. }\end{array}$ & $\begin{array}{l}\text { Visit scheduling; } \\
\text { Separate tools; } \\
\text { Gloves }\end{array}$ \\
\hline $\begin{array}{l}\text { Keep distance, only use your own } \\
\text { equipment etc, wipe gate handles down } \\
\text { etc }\end{array}$ & $\begin{array}{l}\text { Social distancing; } \\
\text { Separate tools; } \\
\text { Disinfection of touchpoints }\end{array}$ \\
\hline $\begin{array}{l}\text { During lockdown and tier } 4 \text { rules such } \\
\text { as restricted opening hours, number al- } \\
\text { lowed to school and hack together, no } \\
\text { more than } 2 \text {. Trying to ensure we not all } \\
\text { up the yard together at the same time } \\
\text { as big livery yard. }\end{array}$ & $\begin{array}{l}\text { Visit scheduling; } \\
\text { Only essential visits/visitors }\end{array}$ \\
\hline
\end{tabular}




\begin{tabular}{|c|c|}
\hline $\begin{array}{l}\text { Everyone needs to check in when they } \\
\text { visit the yard, wear masks if other peo- } \\
\text { ple around, sanitiser to be used before } \\
\text { entering or exiting the barn, only use } \\
\text { our own tools/wheelbarrow/grooming } \\
\text { kit etc. Tack to be taken home as tack } \\
\text { room now out of bounds. }\end{array}$ & $\begin{array}{l}\text { Visit scheduling; } \\
\text { Face mask; } \\
\text { Hand cleaning; } \\
\text { Separate tools; }\end{array}$ \\
\hline $\begin{array}{l}\text { Social distance. Timings. Masks if close } \\
\text { contact. No use of toilets }\end{array}$ & $\begin{array}{l}\text { Social distancing; } \\
\text { Visit scheduling; } \\
\text { Face mask; } \\
\text { Yard facilities shut }\end{array}$ \\
\hline Face, space, wash hands. & $\begin{array}{l}\text { Face mask; } \\
\text { Social distancing; } \\
\text { Hand cleaning }\end{array}$ \\
\hline $\begin{array}{l}\text { No hacking or travelling off yard. No les- } \\
\text { sons. No school bookings. Ride if you } \\
\text { feel it's essential but don't leave the } \\
\text { farm. Don't socialise in groups. } \\
\text { Hand hygiene. }\end{array}$ & $\begin{array}{l}\text { Basic riding/no riding; } \\
\text { Social distancing; } \\
\text { Hand cleaning }\end{array}$ \\
\hline \multirow[t]{2}{*}{$\begin{array}{l}\text { Sign in to track and trace. Hand sanitis- } \\
\text { ers at varies points in yard to be used } \\
\text { when touching communal fixings (e.g. } \\
\text { gates, toilets). Keep } 6 \mathrm{ft} \text { away from } \\
\text { other owners. }\end{array}$} & $\begin{array}{l}\text { Track and Trace App; } \\
\text { Hand cleaning; } \\
\text { Social distancing }\end{array}$ \\
\hline & No details \\
\hline Social distancing, liveries only allowed & $\begin{array}{l}\text { Social distancing; } \\
\text { Only essential visits/visitors }\end{array}$ \\
\hline $\begin{array}{l}\text { Only horse owners or those in direct } \\
\text { care of horse allowed at yard - no visi- } \\
\text { tors. Social distancing to be ad- } \\
\text { hered to. Anyone with any symp- } \\
\text { toms not allowed on yard }\end{array}$ & $\begin{array}{l}\text { Only essential visits/visitors; } \\
\text { Social distancing; } \\
\text { Isolate if contract COVID, or in contact } \\
\text { with someone with COVID }\end{array}$ \\
\hline $\begin{array}{l}\text { Masks on the yard. Time spent a mini- } \\
\text { mum. No visitors. }\end{array}$ & $\begin{array}{l}\text { Face mask; } \\
\text { Only essential visits/visitors }\end{array}$ \\
\hline $\begin{array}{l}\text { Disinfecting surfaces. Distancing. Face } \\
\text { mask inside. Limiting numbers indoors. }\end{array}$ & $\begin{array}{l}\text { Disinfection of touchpoints; } \\
\text { Social distancing; } \\
\text { Face mask }\end{array}$ \\
\hline $\begin{array}{l}\text { In the first lockdown (March/April) } \\
\text { there were allocated time slots for each } \\
\text { livery, however since lockdown re- } \\
\text { strictions easing in July/August there } \\
\text { have been no formal rules at the yard. }\end{array}$ & Visit scheduling \\
\hline
\end{tabular}




\begin{tabular}{|c|c|}
\hline $\begin{array}{l}\text { Stay } 2 \text { m apart. Use own equipment. } \\
\text { Sanitise. Look after own horse. Wear } \\
\text { mask in enclosed areas. }\end{array}$ & $\begin{array}{l}\text { Social distancing; } \\
\text { Separate tools; } \\
\text { Hand cleaning; } \\
\text { No touching of horses by strangers; } \\
\text { Face mask }\end{array}$ \\
\hline $\begin{array}{l}\text { No visitors. No professionals in the } \\
\text { barn. During first lock down, no } \\
\text { coaches. Autumn lock down and tier } 4 \text { - } \\
\text { only } 2 \text { people in each arena at a time. }\end{array}$ & $\begin{array}{l}\text { Only essential visits/visitors; } \\
\text { Social distancing }\end{array}$ \\
\hline $\begin{array}{l}\text { Every owner has a time slot to visit the } \\
\text { yard. }\end{array}$ & Visit scheduling \\
\hline $\begin{array}{l}\text { During lockdown there was a buddy } \\
\text { system in operation - two owners } \\
\text { paired up and went to yard on alternate } \\
\text { days when they would do their own and } \\
\text { other persons horse. Limit on number } \\
\text { of people using the arena at same time. } \\
\text { Under } 16 \text { years accompanied by adult } \\
\text { at all times. Could only hack in } \\
\text { two's. Use own equipment where possi- } \\
\text { ble, sanitising shared equipment. No } \\
\text { gathering in large groups to chat. }\end{array}$ & $\begin{array}{l}\text { Visit scheduling; } \\
\text { Social distancing; } \\
\text { Basic riding/no riding; } \\
\text { Separate tools; } \\
\text { Disinfection of touchpoints }\end{array}$ \\
\hline $\begin{array}{l}\text { Please follow the government advice on } \\
\text { social distancing and handwashing . } \\
\text { Bring you own towel to the yard to dry } \\
\text { your hands on and your own soap and } \\
\text { alcohol hand gel. Do not share towels } \\
\text { for hand drying, use your own. Wash } \\
\text { the towel you bring to the yard daily so } \\
\text { it is fresh every day. Use gloves when } \\
\text { filling hay nets and wash hands with } \\
\text { soap for the required length of time } \\
\text { with gloves on after filling hay nets so } \\
\text { your gloves are clean for next time. One } \\
\text { person at a time in the hay /straw. } \\
\text { store for social distancing reasons } \\
\text { Do not touch items belonging to other } \\
\text { liveries and other people's horses. The } \\
\text { exception to this is if you are providing } \\
\text { livery assistance to someone. If you are } \\
\text { assisting be extra mindful about hand- } \\
\text { washing. Please avoid bringing extra } \\
\text { friends/ family members to the yard for }\end{array}$ & $\begin{array}{l}\text { Social distancing; } \\
\text { Hand cleaning; } \\
\text { Separate tools; } \\
\text { Gloves; } \\
\text { Only essential visits/visitors; } \\
\text { Disinfection of touchpoints; } \\
\text { Face mask; }\end{array}$ \\
\hline
\end{tabular}




\section{the time being. Please bring your own} mug for tea and coffee for hygiene and no more than two people in the tack room at any one time and if more than one person in there please wear a mask. Consider taking your tack home so you can avoid the tack rooms altogether. If you are first to the yard and need to unlock the gate please use alcohol hand gel before you touch the padlock/gate. Leave the gate by the tunnel open during the day to avoid multiple people touching it multiple times. Last person to use it apply alcohol hand gel before you lock it and after to protect yourself and others. Taps for horse washing- use hand gel before and after using. If you have vets /farriers/dentists attending your horse please do this outside the yard if at all possible or ask them to wear a mask if they need to come in the yard.

Please try to avoid spending long periods of time in the barn. Try to get your jobs done quickly and efficiently, this will help achieve social distancing. How long you ride for is obviously up to you! Keep some alcohol hand gel in your pocket and use it whenever you touch an area someone else may have touched.

Specific booked visiting slots - only 2 people on yard at a time. Use hand san-

Visit scheduling; itiser.

No visitors other than essential horse care (vet, farrier, dentist). Only use own equipment. Hand sanitisers and equipment sanitisers. During first lockdown Hand cleaning

Only essential visit/visitors; Separate tools; Hand cleaning; in March, April and May no riding out to reduce accidents and possible pressure on emergency services. 


\begin{tabular}{|c|c|}
\hline $\begin{array}{l}\text { Masks to be worn on the yard. } 2 \text { metres } \\
\text { apart. No people on the yard that aren't } \\
\text { normally there. }\end{array}$ & $\begin{array}{l}\text { Face mask; } \\
\text { Social distancing; } \\
\text { Only essential visits/visitors }\end{array}$ \\
\hline $\begin{array}{l}\text { Individual time slots for visits, masks } \\
\text { must be worn at all times on the yard, } \\
\text { sanitise hands at every gate/door and } \\
\text { only use own tools }\end{array}$ & $\begin{array}{l}\text { Visit scheduling; } \\
\text { Face mask; } \\
\text { Hand cleaning; } \\
\text { Separate tools }\end{array}$ \\
\hline $\begin{array}{l}\text { Keep } 2 \text { meters apart at all times, don't } \\
\text { linger (i.e. do horse and go, don't spend } \\
\text { all day) use hand sanitizer and wash } \\
\text { hands regularly. }\end{array}$ & $\begin{array}{l}\text { Social distancing; } \\
\text { Only essential visits/visitors; } \\
\text { Hand cleaning }\end{array}$ \\
\hline Social distancing & Social distancing \\
\hline $\begin{array}{l}\text { Time slots of max } 2 \text { hrs for livery's to } \\
\text { come up, we have } 4 \text { barns and only one } \\
\text { livery per barn should be up per time } \\
\text { slot. }\end{array}$ & Visit scheduling; \\
\hline $\begin{array}{l}\text { Disinfectant each communal area such } \\
\text { as gates and taps. No friends or unnec- } \\
\text { essary visitors to yard no hacking in } \\
\text { groups. }\end{array}$ & $\begin{array}{l}\text { Disinfection of touch points; } \\
\text { Only essential visits/visitors; } \\
\text { Basic riding/no riding }\end{array}$ \\
\hline $\begin{array}{l}\text { Only owners / loaners at the yard. Hand } \\
\text { sanitizer in common areas. }\end{array}$ & $\begin{array}{l}\text { Only essential visits/visitors; } \\
\text { Hand cleaning }\end{array}$ \\
\hline $\begin{array}{l}\text { No going into their house (we could go } \\
\text { in any time prior to Covid). All bills we } \\
\text { are now able to directly transfer. On } \\
\text { first lockdown I avoided yard altogether } \\
\text { and visited directly to the fields, I didn't } \\
\text { ride at all yet others did. As we are diy } \\
\text { yard and it's now winter we have a few } \\
\text { stabled but we just keep our distance } \\
\text { and use our own tools, I still don't ride } \\
\text { but others do but they limit it to } \\
\text { two/three going out together. }\end{array}$ & $\begin{array}{l}\text { Social distancing; } \\
\text { Basic riding/no riding; } \\
\text { Separate tools }\end{array}$ \\
\hline $\begin{array}{l}\text { Only } 6 \text { people on the yard at ANY time, } \\
\text { including the } 2 \text { yard managers. No just } \\
\text { turning up when you fancy, must book } \\
\text { time slots, max of } 2 \mathrm{hr} \text {. no plus } 1 \text { 's. }\end{array}$ & Visit scheduling; \\
\hline $\begin{array}{l}\text { No authorised visitors. Disinfectant } \\
\text { sprays. Tea room closed. Keeping } \\
\text { distances }\end{array}$ & $\begin{array}{l}\text { Only essential visits/visitors; } \\
\text { Disinfection of touch points; } \\
\text { Yard facilities shut; } \\
\text { Social distancing }\end{array}$ \\
\hline
\end{tabular}




\begin{tabular}{|c|c|}
\hline $\begin{array}{l}\text { No sharers. No visitors other than usual } \\
\text { visitors e.g. partners. }\end{array}$ & Only essential visits/visitors \\
\hline $\begin{array}{l}\text { To socially distance at all times. Not to } \\
\text { touch anyone's tools, belongings. No } \\
\text { visitors to yard unless we have permis- } \\
\text { sion. Limit our time at yard, do your } \\
\text { horse and go. }\end{array}$ & $\begin{array}{l}\text { Social distancing; } \\
\text { Separate tools; } \\
\text { Visit scheduling; } \\
\text { Only essential visit/visitors }\end{array}$ \\
\hline Do your horse \& lease Asap & Only essential visit/visitors \\
\hline $\begin{array}{l}\text { Its grass livery so we make sure that we } \\
\text { arrange not to be around at the same } \\
\text { time. If we do then we adhere to social } \\
\text { distancing rules, face masks and hand } \\
\text { sanitiser. }\end{array}$ & $\begin{array}{l}\text { Visit scheduling; } \\
\text { Social distancing; } \\
\text { Face mask; } \\
\text { Hand cleaning }\end{array}$ \\
\hline $\begin{array}{l}\text { Turn up, do your horse, leave. One per- } \\
\text { son per horse unless the rider is a child } \\
\text { in which case } 1 \text { parent permitted. }\end{array}$ & $\begin{array}{l}\text { Only essential visits/visitors; } \\
\text { Social distancing }\end{array}$ \\
\hline $\begin{array}{l}\text { No social, keep } 2 \text { meters apart from } \\
\text { staff and other liveries. }\end{array}$ & Social distancing \\
\hline $\begin{array}{l}1 \text { person per horse and only farriers and } \\
\text { vets allowed on the yard. }\end{array}$ & $\begin{array}{l}\text { Social distancing; } \\
\text { Only essential visits/visitors }\end{array}$ \\
\hline Masks and social distance & $\begin{array}{l}\text { Face mask; } \\
\text { Social distancing }\end{array}$ \\
\hline Follow social distancing & Social distancing \\
\hline $\begin{array}{l}\text { Once a day yard visits and to maintain } \\
2 m \text { distance. Wipe down equipment be- } \\
\text { fore/after use and an NHS sign in for } \\
\text { the tracking app. }\end{array}$ & $\begin{array}{l}\text { Visit scheduling; } \\
\text { Social distancing; } \\
\text { Disinfection of touchpoints; } \\
\text { Track and trace App }\end{array}$ \\
\hline Masks, social distance. & $\begin{array}{l}\text { Face mask; } \\
\text { Social distancing }\end{array}$ \\
\hline $\begin{array}{l}\text { Social distance when possible. Only use } \\
\text { your tools. Don't hang around for no } \\
\text { reason. Wear mask in enclosed areas. }\end{array}$ & $\begin{array}{l}\text { Social distancing; } \\
\text { Separate tools; } \\
\text { Only essential visits/visitors; } \\
\text { Face mask }\end{array}$ \\
\hline $\begin{array}{l}\text { To ensure when opening shared gate } \\
\text { we wear gloves/sanitise hands. Social } \\
\text { distance at all times, there are only the } \\
\text { owners and me and a friend who rent } \\
\text { the stables. }\end{array}$ & $\begin{array}{l}\text { Gloves; } \\
\text { Hand cleaning; } \\
\text { Social distancing }\end{array}$ \\
\hline $\begin{array}{l}\text { Social distance. Same households only } \\
\text { in arena. }\end{array}$ & $\begin{array}{l}\text { Social distancing; } \\
\text { Bubbles }\end{array}$ \\
\hline $\begin{array}{l}\text { No sharing of tools, sanitise on arrival } \\
\text { on yard. }\end{array}$ & $\begin{array}{l}\text { Separate tools; } \\
\text { Hand cleaning }\end{array}$ \\
\hline
\end{tabular}




\begin{tabular}{|c|c|}
\hline $\begin{array}{l}\text { Depends on Tier. We did have weekly } \\
\text { timed slots when we could visit the } \\
\text { horse (so once a week). Over Christmas } \\
\text { we've been able to go down at any } \\
\text { time, but not allowed to remain in the } \\
\text { tack room, no tea etc and only one per- } \\
\text { son at a time to clean tack. May go back } \\
\text { to timed slots in New Year but tba. }\end{array}$ & $\begin{array}{l}\text { Visit scheduling; } \\
\text { Social distancing }\end{array}$ \\
\hline $\begin{array}{l}\text { No visitors to the yard. Instructors to } \\
\text { come, teach, and leave straight after. }\end{array}$ & Only essential visits/visitors \\
\hline $\begin{array}{l}\text { No friends/guests/visitors. No riding } \\
\text { lessons. Only use your own equipment } \\
\text { Only deal with your horse. Set out a full } \\
\text { care plan, and buddy up with } 1 \text { or } 2 \\
\text { friends, in case you need to isolate and } \\
\text { they need to suddenly care for your } \\
\text { horse. Wash hands. Use sprays pro- } \\
\text { vided at tap points. Brew room is } \\
\text { CLOSED. }\end{array}$ & $\begin{array}{l}\text { Only essential visits/visitors; } \\
\text { Basic riding/no riding; } \\
\text { Separate tools; } \\
\text { No touching of horses by strangers; } \\
\text { Isolate if contract COVID, or in contact } \\
\text { with someone with COVID; } \\
\text { Hand cleaning; } \\
\text { Yard facilities shut }\end{array}$ \\
\hline $\begin{array}{l}\text { No visitors to the yard. Don't hang } \\
\text { about, do your horses and go. }\end{array}$ & Only essential visits/visitors \\
\hline $\begin{array}{l}\text { No people who are not in your bubble } \\
\text { to come onto yard. No lessons during } \\
\text { lockdown. }\end{array}$ & $\begin{array}{l}\text { Bubble; } \\
\text { Basic riding/no riding }\end{array}$ \\
\hline $\begin{array}{l}\text { Keep space between yourselves. Don't } \\
\text { stand around and talk after jobs are } \\
\text { done. }\end{array}$ & Social distancing \\
\hline $\begin{array}{l}\text { As a bhs approved riding school covid } \\
\text { rules are enforced. Signs sanitiser 2-me- } \\
\text { ter rule, masks. }\end{array}$ & $\begin{array}{l}\text { Social distancing; } \\
\text { Hand cleaning; } \\
\text { Face mask }\end{array}$ \\
\hline $\begin{array}{l}\text { During the first lockdown, two-hour } \\
\text { time slots were allocated, only using } \\
\text { your own tools, single person at a time } \\
\text { per horse, no offsite riding, no visitors } \\
\text { apart from vet, farrier, physio, etc. }\end{array}$ & $\begin{array}{l}\text { Visit scheduling; } \\
\text { Separate tools; } \\
\text { Basic riding/no riding; } \\
\text { Only essential visits/visitors }\end{array}$ \\
\hline $\begin{array}{l}\text { Dependant on the rules for our area at } \\
\text { the time, don't hang around/congre- } \\
\text { gate chatting once you've done your } \\
\text { horse. Also only hack out/ride in pairs } \\
\text { while we're in tier } 4 \text {. }\end{array}$ & $\begin{array}{l}\text { Only essential visits/visitors; } \\
\text { Basic riding/no riding }\end{array}$ \\
\hline $\begin{array}{l}\text { Masks and gloves in the stables and } \\
\text { barns. Keep the social distancing guide- } \\
\text { lines. Avoid socialising. }\end{array}$ & $\begin{array}{l}\text { Face mask; } \\
\text { Gloves; } \\
\text { Social distancing }\end{array}$ \\
\hline
\end{tabular}




\begin{tabular}{|c|c|}
\hline $\begin{array}{l}\text { Only allowed Farriers, vets and instruc- } \\
\text { tors. Social distancing at all times. } \\
\text { Washing hands/Sanitisers in wash } \\
\text { room/toilet. Only family members, no } \\
\text { visitors allowed, rota's per horse/pony. } \\
\text { To only use your own tools, i.e.: } \\
\text { wheelbarrow, etc. }\end{array}$ & $\begin{array}{l}\text { Only essential visits/visitors; } \\
\text { Social distancing; } \\
\text { Hand cleaning; } \\
\text { Visit scheduling; } \\
\text { Separate tools }\end{array}$ \\
\hline $\begin{array}{l}\text { Maintain social distancing. Hand wash- } \\
\text { ing and cleaning facilities made availa- } \\
\text { ble. Only visit when necessary. }\end{array}$ & $\begin{array}{l}\text { Social distancing; } \\
\text { Hand cleaning; } \\
\text { Only essential visits/visitors }\end{array}$ \\
\hline $\begin{array}{l}\text { Only } 1 \text { person in tack room at a time. } 2 \\
\text { riders in school at a time - indoor and } \\
\text { outdoor. Stay apart as much as possi- } \\
\text { ble. Hand cleanser supplied. }\end{array}$ & $\begin{array}{l}\text { Social distancing; } \\
\text { Hand cleaning }\end{array}$ \\
\hline $\begin{array}{l}\text { Sanitise hands before entering yard. } \\
\text { No more than } 2 \text { people riding together. } \\
\text { Keep } 2 \mathrm{~m} \text { distance. Don't use any of the } \\
\text { yard tools. }\end{array}$ & $\begin{array}{l}\text { Hand cleaning; } \\
\text { Social distancing; } \\
\text { Separate tools }\end{array}$ \\
\hline $\begin{array}{l}\text { Daily disinfecting of handles/door locks } \\
\text { Time slots to ride - ride and leave. No } \\
\text { visitors. No tea / coffee at present time } \\
\text { or loitering. In first lockdown - no at- } \\
\text { tendance, staff only. }\end{array}$ & $\begin{array}{l}\text { Disinfection of touch points; } \\
\text { Visit scheduling; } \\
\text { Only essential visits/visitors; } \\
\text { Yard facilities shut; } \\
\text { No owner visits }\end{array}$ \\
\hline $\begin{array}{l}\text { Must keep } 2 \text { meters apart and have } \\
\text { yard times. }\end{array}$ & $\begin{array}{l}\text { Social distancing; } \\
\text { Visit scheduling }\end{array}$ \\
\hline $\begin{array}{l}\text { Masks whilst in your barn/stable/tack } \\
\text { room. Gloves at all times. No loitering } \\
\text { Lessons allowed but restricted viewers. }\end{array}$ & $\begin{array}{l}\text { Face mask; } \\
\text { Gloves; } \\
\text { Only essential visits/visitors }\end{array}$ \\
\hline $\begin{array}{l}\text { Hand gel and foot dip on entry and exit, } \\
\text { masks to be worn inside barn, keep dis- } \\
\text { tance, one person per horse, and at the } \\
\text { first lockdown we had time slots. }\end{array}$ & $\begin{array}{l}\text { Hand cleaning; } \\
\text { Foot dip; } \\
\text { Face mask; } \\
\text { Social distancing; } \\
\text { Visit scheduling }\end{array}$ \\
\hline $\begin{array}{l}\text { Wear gloves at all times and use your } \\
\text { own utensils wherever possible. If any- } \\
\text { thing else is touched to be disinfected } \\
\text { with anti bacterial spray/wipes. } 2 \text { me- } \\
\text { tre space between everyone and a re- } \\
\text { striction on how many people on yard } \\
\text { at a time. Certain areas are restricted } \\
\text { from entry - unless a staff member. } \\
\text { Only two horses and people in arena at }\end{array}$ & $\begin{array}{l}\text { Gloves; } \\
\text { Separate tools; } \\
\text { Disinfection of touch points; } \\
\text { Social distancing; } \\
\text { Visit scheduling }\end{array}$ \\
\hline
\end{tabular}




\begin{tabular}{|c|c|}
\hline $\begin{array}{l}\text { a time. Hacks are restricted to two peo- } \\
\text { ple only. Be Safe. }\end{array}$ & \\
\hline $\begin{array}{l}\text { Minimise interaction with others at } \\
\text { yard, observe social distancing, wear } \\
\text { face masks in enclosed areas, use hand } \\
\text { sanitiser on entering/leaving yard. }\end{array}$ & $\begin{array}{l}\text { Social distancing; } \\
\text { Face mask; } \\
\text { Hand cleaning }\end{array}$ \\
\hline $\begin{array}{l}\text { Abide by social distancing and ensure } \\
\text { not at the yard and longer than neces- } \\
\text { sary and stick to tier rules. }\end{array}$ & $\begin{array}{l}\text { Social distancing; } \\
\text { Only essential visits/visitors }\end{array}$ \\
\hline $\begin{array}{l}\text { Wash hands. Keep space unless in dan- } \\
\text { ger. }\end{array}$ & $\begin{array}{l}\text { Hand cleaning; } \\
\text { Social distancing }\end{array}$ \\
\hline $\begin{array}{l}\text { Washing hands when entering and leav- } \\
\text { ing yard. Only being at yard to look af- } \\
\text { ter and exercise horse, no social time. } \\
\text { No friends etc permitted on yard. }\end{array}$ & $\begin{array}{l}\text { Hand cleaning; } \\
\text { Only essential visits/visitors }\end{array}$ \\
\hline $\begin{array}{l}\text { There is a sign from BHS on the tack } \\
\text { room door. All livery owners are ok to } \\
\text { be on the yard but social distancing is } \\
\text { adhered to. All farriers and instruc- } \\
\text { tors are still allowed to visit but no } \\
\text { group lessons. }\end{array}$ & Social distancing; \\
\hline Use your own tools, keep apart & $\begin{array}{l}\text { Separate tools; } \\
\text { Social distancing }\end{array}$ \\
\hline $\begin{array}{l}\text { During initial lockdown in March I was } \\
\text { not allowed to visit the yard to see my } \\
\text { horse at all. Between lockdowns I was } \\
\text { allowed to visit but it had to be when } \\
\text { no one else was on the yard, I could } \\
\text { only attend to my horse \& I needed to } \\
\text { bring my own grooming equipment } \\
\text { with me. During the last lockdown \& } \\
\text { since we have gone into tier } 4 \text { I am } \\
\text { again not allowed to visit my horse at } \\
\text { the yard at all. }\end{array}$ & $\begin{array}{l}\text { No owner visits; } \\
\text { Complete yard lock down; } \\
\text { Visit scheduling; } \\
\text { Social distancing; } \\
\text { Separate tools }\end{array}$ \\
\hline $\begin{array}{l}\text { Book time slots to limit amount of peo- } \\
\text { ple on yard also must wear a face mask } \\
\text { at all times on yard and use hand sani- } \\
\text { tizer stations }\end{array}$ & $\begin{array}{l}\text { Visit scheduling; } \\
\text { Face mask; } \\
\text { Hand cleaning }\end{array}$ \\
\hline
\end{tabular}




\begin{tabular}{|c|c|}
\hline $\begin{array}{l}\text { No visitors except emergency/animal } \\
\text { maintenance. Masks on at all times } \\
\text { while on the yard. Only hack out in } \\
\text { pairs. Tier } 4\end{array}$ & $\begin{array}{l}\text { Only essential visits/visitors; } \\
\text { Face masks; } \\
\text { Social distancing }\end{array}$ \\
\hline $\begin{array}{l}\text { Limited amount of people on the yard } \\
\text { as per tier system (currently } 2 \text { people). } \\
\text { Each using own mucking out tools. No } \\
\text { travelling in to other venues apart from } \\
\text { veterinary care and rehab (ie water } \\
\text { treadmill) }\end{array}$ & $\begin{array}{l}\text { Visit scheduling; } \\
\text { Separate tools; } \\
\text { Basic riding/no riding }\end{array}$ \\
\hline $\begin{array}{l}\text { Masks must be worn in barn and stable } \\
\text { areas, use the handwashing and wear } \\
\text { gloves when opening communal gates } \\
\text { etc. }\end{array}$ & $\begin{array}{l}\text { Face mask; } \\
\text { Hand cleaning; } \\
\text { Gloves }\end{array}$ \\
\hline $\begin{array}{l}\text { Socially distance at all times. No one ex- } \\
\text { cept owners/loaners allowed on yard. } \\
\text { Instructors must go straight to the } \\
\text { school area and no come onto the yard. } \\
\text { Do your horses and go home. Do not } \\
\text { touch other people's equipment. }\end{array}$ & $\begin{array}{l}\text { Social distancing; } \\
\text { Only essential visits/visitors; } \\
\text { Separate tools }\end{array}$ \\
\hline $\begin{array}{l}\text { In the first lock down, we had time slots } \\
\text { and weren't allowed to hack or jump. } \\
\text { At the moment we are just asked to be } \\
\text { sensible. }\end{array}$ & $\begin{array}{l}\text { Visit scheduling; } \\
\text { Basic riding/no riding }\end{array}$ \\
\hline $\begin{array}{l}\text { No visiting to stables only allowed to } \\
\text { see in fields. }\end{array}$ & Only essential visits/visitors \\
\hline $\begin{array}{l}\text { Social distance at all times. No touching } \\
\text { each other's equipment. Only single } \\
\text { person in feed room or enclose area. } \\
\text { No visitors other than household mem- } \\
\text { bers. }\end{array}$ & $\begin{array}{l}\text { Social distancing; } \\
\text { Separate tools; } \\
\text { Only essential visits/visitors } \\
\text { Bubbles }\end{array}$ \\
\hline $\begin{array}{l}\text { Stick to current tier rules or don't come } \\
\text { to yard. Not going in indoor areas. }\end{array}$ & Social distancing \\
\hline $\begin{array}{l}\text { Social distancing, own tool use (no shar- } \\
\text { ing) liveries must arrive at different } \\
\text { times so not more than } 2 \text { on a yard at } \\
\text { any one time, hand sanitise, disinfect } \\
\text { tap (communal) }\end{array}$ & $\begin{array}{l}\text { Social distancing; } \\
\text { Separate tools; } \\
\text { Visit scheduling; } \\
\text { Hand sanitise; } \\
\text { Disinfection of touchpoints }\end{array}$ \\
\hline
\end{tabular}




\begin{tabular}{|c|c|}
\hline $\begin{array}{l}\text { Wear masks (provided). Use hand sani- } \\
\text { tizer (provided). Only attend the yard } \\
\text { when necessary - exercise of horse al- } \\
\text { lowed. Maintain social distancing. } \\
\text { Don't put up jumps in school. Avoid all } \\
\text { unnecessary contact. }\end{array}$ & $\begin{array}{l}\text { Face mask; } \\
\text { Hand cleaning; } \\
\text { Only essential visits/visitors } \\
\text { Basic riding/no riding; } \\
\text { Social distancing }\end{array}$ \\
\hline $\begin{array}{l}2 \mathrm{~m} \text { distance - only } 2 \text { in school or hack- } \\
\text { ing using masks gloves etc when neces- } \\
\text { sary just be sensible! }\end{array}$ & $\begin{array}{l}\text { Social distancing; } \\
\text { Face mask; } \\
\text { Gloves }\end{array}$ \\
\hline $\begin{array}{l}\text { Keep distance and only one person up } \\
\text { per horse. Not many people follow } \\
\text { them unfortunately. }\end{array}$ & Social distancing; \\
\hline Limit numbers of people at one time & Only essential visits/visitors \\
\hline $\begin{array}{l}\text { Keep } 2 \text { metres. Use sanitizer. Only one } \\
\text { person in kitchen at a time. } 1 \text { person in } \\
\text { tack room at a time. } 1 \text { person in feed } \\
\text { room at a time. }\end{array}$ & $\begin{array}{l}\text { Social distancing; } \\
\text { Hand cleaning }\end{array}$ \\
\hline $\begin{array}{l}\text { Hand sanitiser. Avoiding too many peo- } \\
\text { ple on the yard. During first national } \\
\text { lockdown we did not enter the yard but } \\
\text { could get our horse from the field and } \\
\text { ride. Tack etc kept in the car. }\end{array}$ & $\begin{array}{l}\text { Hand cleaning; } \\
\text { Only essential visits/visitors; } \\
\text { Separate tools }\end{array}$ \\
\hline Social distancing, hand sanitiser. & $\begin{array}{l}\text { Social distancing; } \\
\text { Hand cleaning }\end{array}$ \\
\hline Social distancing and allocated times & $\begin{array}{l}\text { Social distancing; } \\
\text { Visit scheduling }\end{array}$ \\
\hline \multirow[t]{2}{*}{$\begin{array}{l}\text { Keep socially distanced at all times. } \\
\text { Sanitise before entering and at exiting } \\
\text { yard. }\end{array}$} & $\begin{array}{l}\text { Social distancing; } \\
\text { Hand cleaning }\end{array}$ \\
\hline & No details \\
\hline $\begin{array}{l}\text { Social distancing, limit time, hacking in } \\
\text { pairs only, no access to tea room facili- } \\
\text { ties. }\end{array}$ & $\begin{array}{l}\text { Social distancing; } \\
\text { Only essential visits/visitor; } \\
\text { Yard facilities shut; } \\
\text { Basic riding/no riding }\end{array}$ \\
\hline $\begin{array}{l}\text { Hand sanitizer provided to be used on } \\
\text { entry to yard. Masks to be worn at all } \\
\text { times except when riding. Only one per- } \\
\text { son allowed in feed room or tack at } \\
\text { same time. All tools to be sprayed with } \\
\text { disinfectant after use. WC sprayed with } \\
\text { disinfectant after use. Numbers on yard } \\
\text { limited and time slots adhered to. }\end{array}$ & $\begin{array}{l}\text { Hand cleaning; } \\
\text { Face mask; } \\
\text { Social distancing; } \\
\text { Disinfection of touchpoints; } \\
\text { Visit scheduling }\end{array}$ \\
\hline
\end{tabular}




\begin{tabular}{|c|c|}
\hline $\begin{array}{l}\text { Social distancing. Not going out in large } \\
\text { groups (government guidelines) and } \\
\text { during first lockdown, we had allocated } \\
\text { times to come down to turn out / muck } \\
\text { out with no riding. Only one person in } \\
\text { indoor spaces like tack and feed room. }\end{array}$ & $\begin{array}{l}\text { Social distancing; } \\
\text { Basic riding/no riding; } \\
\text { Visit scheduling }\end{array}$ \\
\hline $\begin{array}{l}\text { Social distancing. Sanitising stations for } \\
\text { hands, gates and communal areas. } \\
\text { Gloves available to use when touching } \\
\text { shared items or unavoidable items, } \\
\text { head collars and lead ropes. }\end{array}$ & $\begin{array}{l}\text { Social distancing; } \\
\text { Hand cleaning; } \\
\text { Disinfection of touchpoints; } \\
\text { Gloves }\end{array}$ \\
\hline No visiting in tier 4 & $\begin{array}{l}\text { Complete yard lockdown; } \\
\text { No owner visits }\end{array}$ \\
\hline No one unnecessary at the yard & Only essential visits/visitors \\
\hline $\begin{array}{l}\text { Masks at all times. No sharing of equip- } \\
\text { ment. } 1 \text { person per household to attend } \\
\text { the horse. Maximum of two people can } \\
\text { ride in a pair. } 2 \text { hour restriction time. } \\
\text { Only attending to your horse once (ser- } \\
\text { vices at a cost provided). No outside in- } \\
\text { structors. }\end{array}$ & $\begin{array}{l}\text { Face mask; } \\
\text { Separate tools; } \\
\text { Basic riding/no riding; } \\
\text { Visit scheduling; } \\
\text { Only essential visits/visitors }\end{array}$ \\
\hline $\begin{array}{l}\text { One person in feed room/tack room at } \\
\text { a time, one person at hay at a time, so- } \\
\text { cial distancing, nobody other than pri- } \\
\text { mary carer/sharer allowed. }\end{array}$ & $\begin{array}{l}\text { Social distancing; } \\
\text { Only essential visits/visitors }\end{array}$ \\
\hline $\begin{array}{l}\text { Only two other horses / owners. We } \\
\text { rarely overlap and one of them does } 12 \\
\text { hour shifts so very difficult to impose a } \\
\text { "rota" for visiting. But encouraged on } \\
\text { all the distancing measures - which we } \\
\text { do. }\end{array}$ & $\begin{array}{l}\text { Social distancing; } \\
\text { Only essential visits/visitors }\end{array}$ \\
\hline $\begin{array}{l}\text { Keep distance where possible. Clean } \\
\text { any shared items, surfaces regularly } \\
\text { (Wheelbarrows/ tools/ door handles). }\end{array}$ & $\begin{array}{l}\text { Social distancing; } \\
\text { Disinfection of touchpoints }\end{array}$ \\
\hline $\begin{array}{l}\text { Keep } 2 \text { metres from each other. Wash } \\
\text { hands/sanitize on arrival and before } \\
\text { leaving. Wear gloves. Do not stay on } \\
\text { yard any longer than is necessary. }\end{array}$ & $\begin{array}{l}\text { Social distancing; } \\
\text { Hand cleaning; } \\
\text { Gloves; } \\
\text { Only essential visits/visitors }\end{array}$ \\
\hline $\begin{array}{l}\text { Only one person on each of the } 4 \text { areas } \\
\text { of the yard at any one time. } 2 \text { hour time } \\
\text { slots each. }\end{array}$ & $\begin{array}{l}\text { Social distancing; } \\
\text { Visit scheduling }\end{array}$ \\
\hline
\end{tabular}




\begin{tabular}{|c|c|}
\hline $\begin{array}{l}\text { Time slots. Social distancing. Antibacte- } \\
\text { rial spray to clean yard tools with. } \\
\text { Hands to be cleaned and sanitised as of- } \\
\text { ten as possible. }\end{array}$ & $\begin{array}{l}\text { Visit scheduling; } \\
\text { Social distancing; } \\
\text { Hand cleaning }\end{array}$ \\
\hline $\begin{array}{l}\text { Currently: Masks when on site except } \\
\text { when riding. Hand sanitizer at all gates. } \\
\text { No group adult lessons. Must book to } \\
\text { use arena to limit number of people. } \\
\text { Rules have evolved as the situation has } \\
\text { changed. }\end{array}$ & $\begin{array}{l}\text { Face mask; } \\
\text { Hand cleaning; } \\
\text { Basic riding/no riding; } \\
\text { Social distancing }\end{array}$ \\
\hline $\begin{array}{l}\text { No visitors, owners only. We must wash } \\
\text { and sanitise hand on arrival and before } \\
\text { leaving. }\end{array}$ & $\begin{array}{l}\text { Only essential visits/visitors; } \\
\text { Hand cleaning }\end{array}$ \\
\hline $\begin{array}{l}2 \text { metres distance, come in do your } \\
\text { horse and no hanging around together. }\end{array}$ & $\begin{array}{l}\text { Social distancing; } \\
\text { Only essential visits/visitors }\end{array}$ \\
\hline $\begin{array}{l}\text { We all have set times and disinfect after } \\
\text { we've been. }\end{array}$ & $\begin{array}{l}\text { Visit scheduling; } \\
\text { Disinfection of touchpoints }\end{array}$ \\
\hline $\begin{array}{l}\text { Only owner / rider to come up, do your } \\
\text { horse and leave, no going in other } \\
\text { blocks. }\end{array}$ & Only essential visits/visitors \\
\hline $\begin{array}{l}\text { All non-staff wear masks inside. Alcohol } \\
\text { hands on way in to and out of yard. } \\
\text { No access to staff room, kettle etc. Sep- } \\
\text { arate toilet for staff and visitors. Horses } \\
\text { in for rehab facilities to hand horse over } \\
\text { in carpark and not enter the yard and } \\
\text { returned to the owner in yard. }\end{array}$ & $\begin{array}{l}\text { Face mask; } \\
\text { Hand cleaning; } \\
\text { Yard facilities shut; } \\
\text { Social distancing }\end{array}$ \\
\hline $\begin{array}{l}\text { Social distancing. Wash hands regularly. } \\
\text { Buddy with other owners to limit num- } \\
\text { bers on yard. }\end{array}$ & $\begin{array}{l}\text { Social distancing; } \\
\text { Hand cleaning; } \\
\text { Only essential visits/visitors }\end{array}$ \\
\hline $\begin{array}{l}\text { No lessons. Masks. Sanitiser. Set times } \\
\text { to ride. }\end{array}$ & $\begin{array}{l}\text { Basic riding/no riding; } \\
\text { Face mask; } \\
\text { Hand cleaning; } \\
\text { Visit scheduling }\end{array}$ \\
\hline $\begin{array}{l}\text { Only } 3 \text { of us so we have to go at differ- } \\
\text { ent times (where possible). Do not } \\
\text { touch or go near any other horses. } \\
\text { Don't bring anyone else with you \& } \\
\text { keep distance. }\end{array}$ & $\begin{array}{l}\text { Visit scheduling; } \\
\text { No touching of horses by strangers; } \\
\text { Only essential visits/visitors; } \\
\text { Social distancing }\end{array}$ \\
\hline
\end{tabular}




\begin{tabular}{|c|c|}
\hline $\begin{array}{l}\text { No hacking off site. Only one person at } \\
\text { the haylage. If you can share jobs and } \\
\text { come once a day do. No friends or fam- } \\
\text { ily to come with you. }\end{array}$ & $\begin{array}{l}\text { Basic riding/no riding; } \\
\text { Social distancing; } \\
\text { Only essential visits/visitors }\end{array}$ \\
\hline $\begin{array}{l}\text { First lockdown we had time slots. Not } \\
\text { allowed to buy our own feeds (had to } \\
\text { go through them!). Now it's just use } \\
\text { hand sanitizer coming on and off the } \\
\text { yard and stick to social distancing. }\end{array}$ & $\begin{array}{l}\text { Visit scheduling; } \\
\text { Hand cleaning; } \\
\text { Social distancing }\end{array}$ \\
\hline $\begin{array}{l}\text { Disinfect everything that's been } \\
\text { touched, social distancing. }\end{array}$ & $\begin{array}{l}\text { Disinfection of touchpoints; } \\
\text { Social distancing }\end{array}$ \\
\hline No loaners or sharers allowed to yard. & Only essential visits/visitors \\
\hline $\begin{array}{l}\text { No one attending with us. Sole attend- } \\
\text { ance only. Specific times on weekend } \\
\text { days to attend. Sanitiser. }\end{array}$ & $\begin{array}{l}\text { Only essential visits/visitors; } \\
\text { Visit scheduling; } \\
\text { Hand cleaning }\end{array}$ \\
\hline $\begin{array}{l}\text { We are not allowed on the yard all to- } \\
\text { gether hand sanitizer provided and } \\
\text { wash phaticities }\end{array}$ & $\begin{array}{l}\text { Visit scheduling; } \\
\text { Hand cleaning }\end{array}$ \\
\hline $\begin{array}{l}\text { To keep away from each other. Sanitise } \\
\text { on entry and exit. Use your own tools. }\end{array}$ & $\begin{array}{l}\text { Social distancing; } \\
\text { Hand cleaning; } \\
\text { Separate tools }\end{array}$ \\
\hline $\begin{array}{l}\text { Hand gel regularly. We all go at sepa- } \\
\text { rate times (luckily very small yard). } \\
\text { Services (trimmer, vet, edt etc) again all } \\
\text { attend separately. }\end{array}$ & $\begin{array}{l}\text { Hand cleaning; } \\
\text { Visit scheduling; }\end{array}$ \\
\hline $\begin{array}{l}\text { Distancing, hand washing/sanitizing, } \\
\text { number of people in site at any one } \\
\text { time. }\end{array}$ & $\begin{array}{l}\text { Social distancing; } \\
\text { Hand cleaning; } \\
\text { Visit scheduling }\end{array}$ \\
\hline $\begin{array}{l}\text { Original lockdown--only people to use } \\
\text { school and on a booking system. No } \\
\text { yard socialising. Since then no rules. }\end{array}$ & $\begin{array}{l}\text { Visit scheduling; } \\
\text { Social distancing }\end{array}$ \\
\hline $\begin{array}{l}\text { We have an hour, only } 1 \text { person on any } \\
\text { yard at } 1 \text { time (we have } 3 \text { yards). Gloves } \\
\text { to be worn at all times and all tools to } \\
\text { be sanitised. } 2 \mathrm{~m} \text { rules to be followed } \\
\text { when walking past each other. }\end{array}$ & $\begin{array}{l}\text { Visit scheduling; } \\
\text { Gloves; } \\
\text { Disinfection of touchpoints; } \\
\text { Social distancing }\end{array}$ \\
\hline $\begin{array}{l}\text { Use own equipment. Retain personal } \\
\text { space/distance. }\end{array}$ & $\begin{array}{l}\text { Separate tools; } \\
\text { Social distancing }\end{array}$ \\
\hline $\begin{array}{l}\text { Time slots, social distancing, hand sani- } \\
\text { tiser on yard, }\end{array}$ & $\begin{array}{l}\text { Visit scheduling; } \\
\text { Social distancing; } \\
\text { Hand cleaning }\end{array}$ \\
\hline
\end{tabular}




\begin{tabular}{|c|c|}
\hline $\begin{array}{l}\text { Only one person per horse allowed on } \\
\text { the yard so you can't bring family or } \\
\text { friends with you to the yard. Reduce } \\
\text { number of visits if possible and don't } \\
\text { hang around after you have ridden or } \\
\text { done your jobs be as quick as possible. }\end{array}$ & Only essential visits/visitors; \\
\hline Social distance & Social distancing \\
\hline $\begin{array}{l}\text { Time limit of } 2 \text { hours- } 1 \text { person per } \\
\text { horse - hand hygiene on arrival and de- } \\
\text { parture - social distancing }\end{array}$ & $\begin{array}{l}\text { Visit scheduling; } \\
\text { Hand cleaning; } \\
\text { Social distancing }\end{array}$ \\
\hline $\begin{array}{l}\text { Masks on when in indoor spaces, sani- } \\
\text { tize hands before touching communal } \\
\text { items. Ride out only in twos. }\end{array}$ & $\begin{array}{l}\text { Face mask; } \\
\text { Hand cleaning; } \\
\text { Basic riding/no riding }\end{array}$ \\
\hline $\begin{array}{l}\text { Keep distance and in bubbles keep to } \\
\text { your side of yard. No friends or family } \\
\text { to the yard only caregivers. }\end{array}$ & $\begin{array}{l}\text { Social distancing; } \\
\text { Bubbles; } \\
\text { Only essential visits/visitors }\end{array}$ \\
\hline $\begin{array}{l}\text { No visitors when we are in full lock- } \\
\text { down. No loitering and blocking path- } \\
\text { ways. Wash hands when arrive and } \\
\text { leave. No more than } 2 \text { in arenas. Vis- } \\
\text { its to be kept to minimum. }\end{array}$ & $\begin{array}{l}\text { Only essential visits/visitors; } \\
\text { Hand cleaning; } \\
\text { Visit scheduling }\end{array}$ \\
\hline $\begin{array}{l}\text { No riding unpredictable/young horses. } \\
\text { No gathering in groups for chats. }\end{array}$ & $\begin{array}{l}\text { Basic riding/no riding; } \\
\text { Social distancing }\end{array}$ \\
\hline $\begin{array}{l}\text { As it's a very small yard with } 6 \text { people, } \\
\text { we just have hand sanitizer, } 1 \text { person in } \\
\text { tack room at a time, } 2 \text { meters apart and } \\
\text { hacking in pairs only. }\end{array}$ & $\begin{array}{l}\text { Hand cleaning; } \\
\text { Social distancing; } \\
\text { Basic riding/no riding }\end{array}$ \\
\hline $\begin{array}{l}\text { Wash hands upon arrival, before touch- } \\
\text { ing anything. No sharing of tools. } \\
\text { Horses must be tied up (not held in } \\
\text { hand) for farrier/vet/dentist etc. }\end{array}$ & $\begin{array}{l}\text { Hand cleaning; } \\
\text { Separate tools; } \\
\text { Social distancing }\end{array}$ \\
\hline $\begin{array}{l}\text { Only } 1 \text { person per horse to attend daily. } \\
\text { No socialising. Two visits allowed } \\
\text { daily, one } 1 / 2 \text { hour, one } 1 \text { hour and } \\
\text { only for essential care of your horse. } \\
\text { All additional visitors...vets, farriers to } \\
\text { be logged via timetree app. No more } \\
\text { than } 3 \text { people on yard at once. No so- } \\
\text { cialising }\end{array}$ & $\begin{array}{l}\text { Only essential visits/visitors; } \\
\text { Visit scheduling; } \\
\text { Social distancing; } \\
\text { Sign in/out }\end{array}$ \\
\hline
\end{tabular}




\begin{tabular}{|c|c|}
\hline $\begin{array}{l}\text { It's just us two we have separate fields } \\
\text { and stable blocks, we help each other } \\
\text { out when the other is working, we use } \\
\text { our own equipment. The owner is a } \\
\text { nurse and has a test every week, we } \\
\text { have a back up plan to look after each } \\
\text { other We have and do ride to- } \\
\text { gether and she does teach me. We } \\
\text { have kept to the rules. }\end{array}$ & $\begin{array}{l}\text { Separate tools; } \\
\text { Visit scheduling; } \\
\text { Negative test; } \\
\text { Isolate if contract COVID, or in contact } \\
\text { with someone with COVID }\end{array}$ \\
\hline No visitors to touch horses or property. & No touching of horses by strangers \\
\hline $\begin{array}{l}2 \text { people/households only in the stable } \\
\text { and in the manege. If somebody has a } \\
\text { lesson, nobody else is allowed in the } \\
\text { arena }\end{array}$ & $\begin{array}{l}\text { Visit scheduling; } \\
\text { Social distancing }\end{array}$ \\
\hline $\begin{array}{l}\text { Social distance during lockdown } 1 \text { we } \\
\text { had time slots that we had to stick to }\end{array}$ & $\begin{array}{l}\text { Social distancing; } \\
\text { Visit scheduling }\end{array}$ \\
\hline Follow guidelines & $\begin{array}{l}\text { Social distancing; } \\
\text { Hand cleaning; } \\
\text { Face mask }\end{array}$ \\
\hline We sign in and sign out. & Sign in and out \\
\hline $\begin{array}{l}\text { Disinfecting tools, hand sanitiser, not } \\
\text { mixing stable sheds or riding groups }\end{array}$ & $\begin{array}{l}\text { Disinfection of touchpoints; } \\
\text { Hand cleaning; } \\
\text { Social distancing; } \\
\text { Basic riding/no riding }\end{array}$ \\
\hline $\begin{array}{l}\text { Time slots to visit yard to keep numbers } \\
\text { below threshold. }\end{array}$ & Visit scheduling \\
\hline Keep 2 metres apart. & Social distancing \\
\hline $\begin{array}{l}\text { Wash hands, social distance, no group } \\
\text { gathering. }\end{array}$ & $\begin{array}{l}\text { Hand cleaning; } \\
\text { Social distancing }\end{array}$ \\
\hline $\begin{array}{l}\text { Social distancing. Frequent hand wash- } \\
\text { ing including on arrival and departure. } \\
\text { Tea room for staff only. During first lock } \\
\text { down had time slots to avoid too many } \\
\text { people on the yard at once. }\end{array}$ & $\begin{array}{l}\text { Social distancing; } \\
\text { Hand cleaning; } \\
\text { Yard facilities shut; } \\
\text { Visit scheduling }\end{array}$ \\
\hline $\begin{array}{l}\text { Not too many people up at the same } \\
\text { time }\end{array}$ & Visit scheduling \\
\hline $\begin{array}{l}\text { Use own stuff. } 1 \text { person in feed } \\
\text { room/tack room. If using anything } \\
\text { hand sanitise before and after. Tie up } \\
\text { away from others. }\end{array}$ & $\begin{array}{l}\text { Separate tools; } \\
\text { Social distancing; } \\
\text { Hand cleaning }\end{array}$ \\
\hline
\end{tabular}




\begin{tabular}{|c|c|}
\hline $\begin{array}{l}\text { Social distance, no sharing tools, hand } \\
\text { sanitiser at all gates, limited people in } \\
\text { yard at any time, only necessary profes- } \\
\text { sionals (vet/farrier) allowed }\end{array}$ & $\begin{array}{l}\text { Social distancing; } \\
\text { Separate tools; } \\
\text { Hand cleaning; } \\
\text { Visit scheduling; } \\
\text { Only essential visits/visitors }\end{array}$ \\
\hline $\begin{array}{l}\text { Face covering to be worn. Washing } \\
\text { hands. No groups/standing together. } \\
\text { Limit time spent at the yard. }\end{array}$ & $\begin{array}{l}\text { Face mask; } \\
\text { Hand cleaning; } \\
\text { Social distancing; } \\
\text { Only essential visits/visitors }\end{array}$ \\
\hline $\begin{array}{l}\text { Sign in using covid app. Keep } 2 \text { metre } \\
\text { distance. Only see to your horses. Do } \\
\text { not gather indoors ie Tack room. }\end{array}$ & $\begin{array}{l}\text { Track and Trace App; } \\
\text { Social distancing; } \\
\text { Only essential visits/visitors; }\end{array}$ \\
\hline $\begin{array}{l}\text { No more than } 4 \text { people on yard. } 2 \text { hour } \\
\text { slots. Hand sanitizer. }\end{array}$ & $\begin{array}{l}\text { Visit scheduling; } \\
\text { Hand cleaning }\end{array}$ \\
\hline $\begin{array}{l}\text { Avoid bringing people unneeded to the } \\
\text { yard, no horses on and off the yard } \\
\text { when in lockdown }\end{array}$ & $\begin{array}{l}\text { Only essential visits/visitors; } \\
\text { Basic riding/no riding }\end{array}$ \\
\hline $\begin{array}{l}\text { Strict rota for attending. Hand sanitizer } \\
\text { stations. Bleach sprays for gates. One at } \\
\text { time in feed room or hay bales. Buddy } \\
\text { system. Limited riding first lockdown. }\end{array}$ & $\begin{array}{l}\text { Visit scheduling; } \\
\text { Hand cleaning; } \\
\text { Disinfection of touchpoints; } \\
\text { Social distancing; } \\
\text { Basic riding }\end{array}$ \\
\hline $\begin{array}{l}\text { Don't share tools, wear masks, sanitised } \\
\text { hands regularly. }\end{array}$ & $\begin{array}{l}\text { Separate tools; } \\
\text { Face mask; } \\
\text { Hand cleaning }\end{array}$ \\
\hline $\begin{array}{l}\text { Social distancing. Limited liveries on the } \\
\text { yard. Time slots for riding and jobs. }\end{array}$ & $\begin{array}{l}\text { Social distancing; } \\
\text { Visit scheduling }\end{array}$ \\
\hline $\begin{array}{l}\text { Wear masks in yard. Limit to number } \\
\text { on yard during first lockdown. Social } \\
\text { distancing. }\end{array}$ & $\begin{array}{l}\text { Face mask; } \\
\text { Visit scheduling; } \\
\text { Social distancing } \\
\end{array}$ \\
\hline $\begin{array}{l}\text { Wash hands on arrival and before we } \\
\text { leave. Keep social distance from other } \\
\text { people on yard }\end{array}$ & $\begin{array}{l}\text { Hand cleaning; } \\
\text { Social distancing }\end{array}$ \\
\hline $\begin{array}{l}\text { Masks at all times, social distancing or } \\
\text { get kicked off, proof of a negative test } \\
\text { to be allowed on. }\end{array}$ & $\begin{array}{l}\text { Face mask; } \\
\text { Social distancing; } \\
\text { Negative test }\end{array}$ \\
\hline $\begin{array}{l}\text { Masks to be worn in shop, only two } \\
\text { people in at a time. Only people with } \\
\text { horses on yard allowed down. }\end{array}$ & $\begin{array}{l}\text { Face mask; } \\
\text { Social distancing; } \\
\text { Only essential visits/visitors }\end{array}$ \\
\hline
\end{tabular}




\begin{tabular}{|c|c|}
\hline $\begin{array}{l}\text { Distance, masks, no extra people, jobs } \\
\text { and ride and go. No hacking in big } \\
\text { groups. Depending on restrictions de- } \\
\text { pends if indoor used or not }\end{array}$ & $\begin{array}{l}\text { Social distancing; } \\
\text { Only essential visit/visitors; } \\
\text { Basic riding/no riding }\end{array}$ \\
\hline & No details \\
\hline $\begin{array}{l}\text { No people outside the yard (except vet, } \\
\text { farrier, physio, instructors etc.) to come } \\
\text { onto the yard unless it's someone you } \\
\text { live with and they are helping you out. } \\
\text { Wash/ sanitise yard when you enter } \\
\text { and when you leave the yard. }\end{array}$ & $\begin{array}{l}\text { Only essential visits/visitors; } \\
\text { Disinfection of touchpoints }\end{array}$ \\
\hline Social distancing. Sanitising. & $\begin{array}{l}\text { Social distancing; } \\
\text { Disinfection of touchpoints }\end{array}$ \\
\hline & No details \\
\hline $\begin{array}{l}\text { Wear masks in Barns. Minimal visitors, } \\
\text { limited access if in tier } 4 \text { so as to not } \\
\text { mix with other liveries. }\end{array}$ & $\begin{array}{l}\text { Face mask; } \\
\text { Only essential visits/visitors; } \\
\text { Social distancing }\end{array}$ \\
\hline $\begin{array}{l}\text { Social distancing. During first lockdown } \\
\text { only } 2 \text { people on the yard at any one } \\
\text { time, monitored by time slots. No hack- } \\
\text { ing initially and no jumping. }\end{array}$ & $\begin{array}{l}\text { Social distancing; } \\
\text { Visit scheduling; } \\
\text { Basic riding/no riding }\end{array}$ \\
\hline Times, masks, keep separate. & $\begin{array}{l}\text { Visit scheduling; } \\
\text { Face mask; } \\
\text { Social distancing }\end{array}$ \\
\hline $\begin{array}{l}\text { Not to gather in communal spaces and } \\
\text { to follow govt guidance and social dis- } \\
\text { tancing at all times. }\end{array}$ & Social distancing \\
\hline $\begin{array}{l}\text { No visitors to yard except for welfare } \\
\text { purposes. Log all details. Nobody to visit } \\
\text { with you if you don't live with them. } \\
\text { Don't go to yard owners house with is- } \\
\text { sues, call them instead. }\end{array}$ & $\begin{array}{l}\text { Only essential visits/visitors; } \\
\text { Sign in/out }\end{array}$ \\
\hline General guidelines and staggered times & Visit scheduling \\
\hline $\begin{array}{l}\text { No children and no contact with others } \\
\text { belongings (easy as small yard with own } \\
\text { paddocks and not communal areas for } \\
\text { feed etc.) }\end{array}$ & $\begin{array}{l}\text { Social distancing; } \\
\text { Separate tools }\end{array}$ \\
\hline Stay socially distance. & Social distancing \\
\hline Abide by social distancing & Social distancing \\
\hline $\begin{array}{l}\text { Space, anti bac spray used on all com- } \\
\text { munal areas. Taps and gates sprayed. } \\
\text { No mixing in tack rooms. }\end{array}$ & $\begin{array}{l}\text { Social distancing; } \\
\text { Hand cleaning; } \\
\text { Disinfection of touchpoints }\end{array}$ \\
\hline
\end{tabular}




\begin{tabular}{|c|c|}
\hline $\begin{array}{l}\text { During the first lockdown time slots } \\
\text { were implemented to limit the number } \\
\text { of people on the yard at one time, and } \\
\text { riding wasn't allowed. After that, the re- } \\
\text { strictions have been relaxed to social } \\
\text { distancing and masks in the barns/tack } \\
\text { rooms and kitchen. }\end{array}$ & $\begin{array}{l}\text { Visit scheduling; } \\
\text { Basic riding/no riding; } \\
\text { Face mask }\end{array}$ \\
\hline $\begin{array}{l}\text { Keep distanced, use hand sanitiser, only } \\
2 \text { allowed in tack /feed room at a time, } \\
\text { keep door open. }\end{array}$ & $\begin{array}{l}\text { Social distancing; } \\
\text { Hand cleaning }\end{array}$ \\
\hline $\begin{array}{l}\text { Keep distance, masks to be worn in } \\
\text { shared areas, use your own tools / kit. }\end{array}$ & $\begin{array}{l}\text { Social distancing; } \\
\text { Face mask; } \\
\text { Separate tools }\end{array}$ \\
\hline $\begin{array}{l}\text { Social distancing where possible and } \\
\text { staggered arrival times }\end{array}$ & $\begin{array}{l}\text { Social distancing; } \\
\text { Visit scheduling }\end{array}$ \\
\hline $\begin{array}{l}\text { Face masks to be worn at all times on } \\
\text { the yard unless riding or unless you } \\
\text { have an exemption. Only } 2 \text { people to } \\
\text { ride in a school at once with social dis- } \\
\text { tancing. General social distancing } \\
\text { rules. }\end{array}$ & $\begin{array}{l}\text { Face mask; } \\
\text { Basic riding/no riding; } \\
\text { Social distancing }\end{array}$ \\
\hline $\begin{array}{l}\text { Visits to be kept to a minimum and for } \\
\text { short periods - or based on a schedule. } \\
\text { No lessons for over } 18 \text { 's Only } 4 \text { people } \\
\text { to use the school at a time Masks to } \\
\text { be worn in the office, or when standing } \\
\text { and chatting to people Hand sanitiser } \\
\text { is available for use, please use it Only } \\
2 \text { adults to go for a hack together }\end{array}$ & $\begin{array}{l}\text { Only essential visits; } \\
\text { Basic riding/no riding; } \\
\text { Visit scheduling; } \\
\text { Face mask; } \\
\text { Hand cleaning; } \\
\text { Social distancing }\end{array}$ \\
\hline $\begin{array}{l}\text { One rider at time in arena. Book time at } \\
\text { yard. Jobs ride home no loitering. } \\
\text { No one on yard except liveries and } \\
\text { staff. }\end{array}$ & $\begin{array}{l}\text { Visit scheduling; } \\
\text { Only essential visits/visitors }\end{array}$ \\
\hline $\begin{array}{l}2 \text { metre distance at all times. Masks to } \\
\text { be worn when inside. Hand washing } \\
\text { and sanitising. }\end{array}$ & $\begin{array}{l}\text { Social distancing; } \\
\text { Face mask; } \\
\text { Hand cleaning }\end{array}$ \\
\hline $\begin{array}{l}\text { Wear gloves. No visitors to touch gates. } \\
\text { Disinfect anything touched with hands. } \\
\text { Use own equipment only. }\end{array}$ & $\begin{array}{l}\text { Gloves; } \\
\text { Disinfection of touch points; } \\
\text { Separate tools }\end{array}$ \\
\hline $\begin{array}{l}\text { No mixing only one at a time in feed } \\
\text { room tack room masks at all times. }\end{array}$ & $\begin{array}{l}\text { Social distancing; } \\
\text { Face mask }\end{array}$ \\
\hline
\end{tabular}




\begin{tabular}{|c|c|}
\hline $\begin{array}{l}\text { We are only allowed to attend the yard } \\
\text { with people in our bubble, arena hires } \\
\text { and lessons are no longer allowed. }\end{array}$ & $\begin{array}{l}\text { Bubbles; } \\
\text { Basic riding/no riding }\end{array}$ \\
\hline $\begin{array}{l}2 \text { hour only slots } 2 x \text { a day and no leav- } \\
\text { ing the property to ride. } 2 \mathrm{~m} \text { rule in } \\
\text { barns. }\end{array}$ & $\begin{array}{l}\text { Visit scheduling; } \\
\text { Social distancing; } \\
\text { Basic riding/no riding; }\end{array}$ \\
\hline $\begin{array}{l}\text { Wear mask when in barn, use horses } \\
\text { own stall to groom and tack up to re- } \\
\text { duce use of common areas, let barn } \\
\text { know what time you are coming to re- } \\
\text { duce the number of people there at a } \\
\text { time. }\end{array}$ & $\begin{array}{l}\text { Face mask; } \\
\text { Separate tools; } \\
\text { Visit scheduling }\end{array}$ \\
\hline $\begin{array}{l}\text { Assigned 3h time slots to help ensure } \\
\text { we don't all arrive at the same time. } \\
\text { Flexible slots which we organise } \\
\text { amongst ourselves but will be made } \\
\text { stricter / less flexible if we have persis- } \\
\text { tent issues with over crowding. Use } \\
\text { own kit only where possible. If sharing } \\
\text { anything wear gloves and wipe down } \\
\text { after use. } 2 \text { m Apart. If barn is full don't } \\
\text { use central aisle but go to riding school } \\
\text { stables (riding school closed in tier } 4 \text { ). } \\
\text { Max number of people in school to be } \\
\text { observed. Use virkon provided to clean } \\
\text { gate latches after using school. Hand } \\
\text { washing facilities available for arrival, } \\
\text { departure. Any visitors (farrier, vet) to } \\
\text { be made aware of covid protocol. No } \\
\text { guests ie don't bring whole Family } \\
\text { down and no loitering chatting. }\end{array}$ & $\begin{array}{l}\text { Visit scheduling; } \\
\text { Separate tools; } \\
\text { Gloves; } \\
\text { Disinfection of touchpoints; } \\
\text { Social distancing; } \\
\text { Hand cleaning; } \\
\text { Only essential visits/visitors }\end{array}$ \\
\hline Visiting time by appointment & Visit scheduling \\
\hline $\begin{array}{l}\text { Limited visitors, must wash hands on ar- } \\
\text { rive }\end{array}$ & $\begin{array}{l}\text { Hand cleaning; } \\
\text { Only essential visits/visitors }\end{array}$ \\
\hline $\begin{array}{l}\text { Covid barcode scan. During March } \\
\text { lockdown there was allocated time slots } \\
\text { to attend your horse. Now recom- } \\
\text { mended booking the school and hand } \\
\text { washing. }\end{array}$ & $\begin{array}{l}\text { Track and Trace app; } \\
\text { Visit scheduling; } \\
\text { Hand cleaning }\end{array}$ \\
\hline
\end{tabular}




\begin{tabular}{|c|c|}
\hline $\begin{array}{l}2 \mathrm{~m} \text { social distancing. Hand washing and } \\
\text { sanitizing. They would wipe down sur- } \\
\text { faces every day. Nobody on the yard } \\
\text { unless directly involved in looking after } \\
\text { the horse/pony. }\end{array}$ & $\begin{array}{l}\text { Social distancing; } \\
\text { Hand cleaning; } \\
\text { Disinfection of touchpoints; } \\
\text { Only essential visits/visitors }\end{array}$ \\
\hline Social distancing and hand sanitizer & $\begin{array}{l}\text { Social distancing; } \\
\text { Hand cleaning }\end{array}$ \\
\hline $\begin{array}{l}\text { Socially distance. Only } 2 \text { adults on the } \\
\text { yard at any time. Book in a time for } \\
\text { using school etc. Wear gloves. Sani- } \\
\text { tise all handles, switches etc. }\end{array}$ & $\begin{array}{l}\text { Social distancing; } \\
\text { Visit scheduling; } \\
\text { Gloves; } \\
\text { Disinfection of touchpoints; } \\
\text { Hand cleaning }\end{array}$ \\
\hline $\begin{array}{l}\text { Only two liveries allowed on yard at a } \\
\text { time. Social distancing to be maintained } \\
\text { at all times. Allocated time slot for } \\
\text { mucking out. Only one person allowed } \\
\text { in tack room at a time. Shared areas, } \\
\text { tools, taps etc to be wiped down when } \\
\text { finished. Hand sanitizer to be used on } \\
\text { arrival. }\end{array}$ & $\begin{array}{l}\text { Visit scheduling; } \\
\text { Social distancing; } \\
\text { Disinfection of touchpoints; } \\
\text { Hand cleaning }\end{array}$ \\
\hline Social distancing. & Social distancing \\
\hline $\begin{array}{l}\text { We are not to go near their house and } \\
\text { there shouldn't be more than one per- } \\
\text { son looking after each horse at one } \\
\text { time. Exception for those under } 16 \text {. }\end{array}$ & $\begin{array}{l}\text { Only essential visits/visitors; } \\
\text { Social distancing }\end{array}$ \\
\hline $\begin{array}{l}\text { Basic. Two metres apart at all times. } \\
\text { Only one horse allowed in the school at } \\
\text { a time. }\end{array}$ & $\begin{array}{l}\text { Social distancing; } \\
\text { Visit scheduling }\end{array}$ \\
\hline $\begin{array}{l}\text { When restrictions first landed horses } \\
\text { were to stay out in field and nobody go } \\
\text { up. We negotiated a } 2 \text { person max } \\
\text { rule and worked out suitable time slots } \\
\text { for groups to help each other out. } \\
\text { Horses were not ridden for } 6 \text { weeks. } \\
\text { Since relaxations of lockdown yard } \\
\text { owner is happy as long as we keep dis- } \\
\text { tance between ourselves and ensure } \\
\text { any care professionals e.g. farrier work } \\
\text { outdoors and masks to be worn at } \\
\text { those interactions. We have gone from } \\
\text { using towels to dry out hands to paper } \\
\text { towels and extra cleaning supplies have } \\
\text { been provided for common areas. }\end{array}$ & $\begin{array}{l}\text { Complete yard lock down; } \\
\text { No owner visits; } \\
\text { Visit scheduling; } \\
\text { Basic riding/no riding } \\
\text { Social distancing; } \\
\text { Face mask; } \\
\text { Disinfection of touchpoints }\end{array}$ \\
\hline
\end{tabular}




\begin{tabular}{|c|c|}
\hline $\begin{array}{l}\text { Limited time at yard. Wear masks at all } \\
\text { time. Hand sanitizer on yard. Do not } \\
\text { come on yard if showing symptoms } \\
\text { been in contact with someone etc. Stay } \\
2 \mathrm{~m} \text { apart }\end{array}$ & $\begin{array}{l}\text { Visit scheduling; } \\
\text { Face mask; } \\
\text { Hand cleaning; } \\
\text { Social distancing; } \\
\text { Isolate if contract COVID, or in contact } \\
\text { with someone with COVID }\end{array}$ \\
\hline $\begin{array}{l}\text { Sanitise hands regularly. Fill out track } \\
\text { and trace info and record times at yard. } \\
\text { No sharing of tools. Keep } 2 \mathrm{M} \text { distance. } \\
\text { Any Covid } 19 \text { symptoms then do not } \\
\text { come up. }\end{array}$ & $\begin{array}{l}\text { Hand cleaning; } \\
\text { Track and Trace App; } \\
\text { Separate tools; } \\
\text { Social distancing; } \\
\text { Isolate if contract COVID, or in contact } \\
\text { with someone with COVID }\end{array}$ \\
\hline $\begin{array}{l}\text { Social distancing at all times. Hand Gel } \\
\text { before going in/leaving school. All } \\
\text { jumps/poles etc put away after use. No } \\
\text { communal kettles/cups etc. No congre- } \\
\text { gating in closed spaces. Soap/hand gel } \\
\text { in toilet. }\end{array}$ & $\begin{array}{l}\text { Social distancing; } \\
\text { Hand cleaning; }\end{array}$ \\
\hline $\begin{array}{l}\text { Time slots of when we can go to the } \\
\text { yard. Use of arenas and equipment } \\
\text { monitored. }\end{array}$ & Visit scheduling \\
\hline $\begin{array}{l}\text { Keep distance, wear a mask if in a } \\
\text { group. }\end{array}$ & $\begin{array}{l}\text { Social distancing; } \\
\text { Face mask }\end{array}$ \\
\hline $\begin{array}{l}\text { No visitors, sanitise including any tools } \\
\text { touched }\end{array}$ & $\begin{array}{l}\text { Only essential visits/visitors; } \\
\text { Disinfection of touchpoints }\end{array}$ \\
\hline $\begin{array}{l}\text { No helping with each other's horses. } \\
\text { Not be on yard at same time. }\end{array}$ & $\begin{array}{l}\text { Visit scheduling; } \\
\text { No touching of horses by strangers }\end{array}$ \\
\hline $\begin{array}{l}\text { Limited numbers on site, distancing, } \\
\text { limited numbers in indoor areas at the } \\
\text { same time, masks indoors, no sharing } \\
\text { tools, sign in book, on site only for care } \\
\text { or exercising then leave. }\end{array}$ & $\begin{array}{l}\text { Visit scheduling; } \\
\text { Social distancing; } \\
\text { Face masks; } \\
\text { Separate tools; } \\
\text { Sign in/out; } \\
\text { Only essential visits/visitors }\end{array}$ \\
\hline $\begin{array}{l}\text { Only use own equipment, masks on if } \\
\text { around other. }\end{array}$ & $\begin{array}{l}\text { Separate tools; } \\
\text { Face mask }\end{array}$ \\
\hline $\begin{array}{l}\text { Only us allowed no visitors - but private } \\
\text { yard at home. Farrier allowed but so- } \\
\text { cially distanced and hand wash entry } \\
\text { and exit - only touched horses limbs. I } \\
\text { am the vet. }\end{array}$ & $\begin{array}{l}\text { Only essential visits/visitors; } \\
\text { Social distancing; } \\
\text { Hand cleaning }\end{array}$ \\
\hline
\end{tabular}




\begin{tabular}{|c|c|}
\hline $\begin{array}{l}\text { Use of disinfectant. During first lock } \\
\text { down, we had time slots to visit and rid- } \\
\text { ing was restricted. This all then eased, } \\
\text { and everything went pretty much back } \\
\text { to normal. }\end{array}$ & $\begin{array}{l}\text { Disinfection of touchpoints; } \\
\text { Visit scheduling; } \\
\text { Basic riding/no riding }\end{array}$ \\
\hline $\begin{array}{l}\text { One person per horse. Gloves to be } \\
\text { worn at all times. Only one person in } \\
\text { tack room and feed room at a time and } \\
\text { always keep distant. Once done your } \\
\text { horse leave. }\end{array}$ & $\begin{array}{l}\text { Social distancing; } \\
\text { Gloves; } \\
\text { Only essential visits/visitors }\end{array}$ \\
\hline Rotas and hand sanitizer. & $\begin{array}{l}\text { Visit scheduling; } \\
\text { Hand cleaning }\end{array}$ \\
\hline $\begin{array}{l}\text { Masks indoors, maintain social distance, } \\
\text { use only own tools, sanitise hands, use } \\
\text { antibacterial spray and wipes for taps } \\
\text { etc }\end{array}$ & $\begin{array}{l}\text { Face mask; } \\
\text { Social distancing; } \\
\text { Separate tools; } \\
\text { Hand cleaning; } \\
\text { Disinfection of touchpoints }\end{array}$ \\
\hline $\begin{array}{l}\text { Limit time at yard, no socialising inside, } \\
\text { wash hands. }\end{array}$ & $\begin{array}{l}\text { Visit scheduling; } \\
\text { Hand cleaning; } \\
\text { Social distancing }\end{array}$ \\
\hline $\begin{array}{l}\text { Social distancing. Certain times for each } \\
\text { person to be there. No sharers present } \\
\text { without yard owners consent. Hand } \\
\text { washing etc. }\end{array}$ & $\begin{array}{l}\text { Social distancing; } \\
\text { Visit scheduling; } \\
\text { Only essential visits/visitors; } \\
\text { Hand cleaning } \\
\end{array}$ \\
\hline Distance and hand sanitizer & $\begin{array}{l}\text { Social distancing; } \\
\text { Hand cleaning }\end{array}$ \\
\hline $\begin{array}{l}2 \text { metres apart, sanitising stations, } \\
\text { don't touch other people's horses tack } \\
\text { etc, 1-1 private lessons only, try to } \\
\text { come to the yard, if possible, when oth- } \\
\text { ers are not there. }\end{array}$ & $\begin{array}{l}\text { Social distancing; } \\
\text { Hand cleaning; } \\
\text { Basic riding/no riding; } \\
\text { Visit scheduling }\end{array}$ \\
\hline $\begin{array}{l}\text { Masks to be worn, temperature meas- } \\
\text { uring before entry, sign in and out and } \\
\text { don't hang around talking to people } \\
\text { (ride and leave), wipe down saddle, } \\
\text { hand gel before yard entry. }\end{array}$ & $\begin{array}{l}\text { Face mask; } \\
\text { Temperature check; } \\
\text { Sign in/out; } \\
\text { Only essential visits/visitors; } \\
\text { Disinfection of touchpoints } \\
\text { Hand cleaning }\end{array}$ \\
\hline $\begin{array}{l}\text { Wash hands, spray with disinfectant. Be } \\
\text { sensible. No external visitors. }\end{array}$ & $\begin{array}{l}\text { Hand cleaning; } \\
\text { Disinfection of touchpoints; } \\
\text { Only essential visits/visitors }\end{array}$ \\
\hline
\end{tabular}




\begin{tabular}{|c|c|}
\hline $\begin{array}{l}\text { Masks worn in inside areas, social dis- } \\
\text { tancing, no visitors or additional people } \\
\text { on yard. }\end{array}$ & $\begin{array}{l}\text { Face mask; } \\
\text { Social distancing; } \\
\text { Only essential visits/visitors; }\end{array}$ \\
\hline $\begin{array}{l}\text { Social distance. Sanitize hands. Only } 1 \\
\text { person in tack and feed room. }\end{array}$ & $\begin{array}{l}\text { Social distancing; } \\
\text { Hand cleaning }\end{array}$ \\
\hline $\begin{array}{l}\text { Reduced numbers at yard at any time. } \\
\text { We are all expected to adhere to rules } \\
\text { at all times and when not at yard re- } \\
\text { duce contacts. }\end{array}$ & $\begin{array}{l}\text { Visit scheduling; } \\
\text { Social distancing }\end{array}$ \\
\hline $\begin{array}{l}\text { No extra visitors. Keeping distance from } \\
\text { each other. }\end{array}$ & $\begin{array}{l}\text { Only essential visits/visitors; } \\
\text { Social distancing }\end{array}$ \\
\hline $\begin{array}{l}\text { Sanitise hands at gate. Use own equip- } \\
\text { ment or sanitise yard equipment before } \\
\text { and after use. }\end{array}$ & $\begin{array}{l}\text { Hand cleaning; } \\
\text { Separate tools; } \\
\text { Disinfection of touchpoints }\end{array}$ \\
\hline $\begin{array}{l}\text { Only do essential tasks. Ride in pairs } \\
\text { only out. Tea room closed. } 2 \text { riders in } \\
\text { indoor school at a time. No congrega- } \\
\text { tion. Wash hands entering and leaving } \\
\text { yard. Only owners and sharers on yard. }\end{array}$ & $\begin{array}{l}\text { Basic riding/no riding; } \\
\text { Yard facilities shut; } \\
\text { Social distancing; } \\
\text { Only essential visits/visitors }\end{array}$ \\
\hline $\begin{array}{l}\text { Use hand sanitizer, limited people in } \\
\text { arenas, maintain social distancing. }\end{array}$ & $\begin{array}{l}\text { Hand cleaning; } \\
\text { Visit scheduling; } \\
\text { Social distancing } \\
\end{array}$ \\
\hline Had sanitation, social distance. & $\begin{array}{l}\text { Hand cleaning; } \\
\text { Social distancing }\end{array}$ \\
\hline $\begin{array}{l}\text { Certain number of people at yard, no } \\
\text { mixing inside tack room, at times no } \\
\text { leaving the yard unless for medical rea- } \\
\text { sons. If you're irresponsible as an } \\
\text { owner, then you can't come to the yard } \\
\text { until you have isolated. }\end{array}$ & $\begin{array}{l}\text { Visit scheduling; } \\
\text { Social distancing; } \\
\text { Isolate if contract COVID, or in contact } \\
\text { with someone with COVID }\end{array}$ \\
\hline $\begin{array}{l}\text { Limited people on site, hand washing, } \\
\text { booked slots and social distancing }\end{array}$ & $\begin{array}{l}\text { Visit scheduling; } \\
\text { Hand cleaning; } \\
\text { Social distancing } \\
\end{array}$ \\
\hline $\begin{array}{l}\text { Wearing masks. One person in tack } \\
\text { room / hay area at a time. No extra } \\
\text { people (e.g. friends, family) on yard. }\end{array}$ & $\begin{array}{l}\text { Face mask; } \\
\text { Social distancing; } \\
\text { Only essential visits/visitors }\end{array}$ \\
\hline Social distancing and time slots. & $\begin{array}{l}\text { Social distancing; } \\
\text { Visit scheduling }\end{array}$ \\
\hline
\end{tabular}




\begin{tabular}{|c|c|}
\hline $\begin{array}{l}\text { Sanitize all gates used \& anything com- } \\
\text { munal you touch. Sanitize toilet after } \\
\text { use. Don't go up if isolating or tested } \\
\text { positive. }\end{array}$ & $\begin{array}{l}\text { Disinfection of touchpoints; } \\
\text { Isolate if contract COVID, or in contact } \\
\text { with someone with COVID }\end{array}$ \\
\hline $\begin{array}{l}\text { Social Distancing - } 2 \text { mtrs apart. Hand } \\
\text { sanitise on arrival \& departure to yard. } \\
\text { Hand wash / sanitiser at various points. } \\
\text { No visitors apart from professionals (vet } \\
\text { / farrier). Lessons only individual (dur- } \\
\text { ing lock down). Use own tools. }\end{array}$ & $\begin{array}{l}\text { Social distancing; } \\
\text { Hand cleaning; } \\
\text { Only essential visits/visitors; } \\
\text { Basic riding/no riding; } \\
\text { Separate tools }\end{array}$ \\
\hline Sanitisation. No visitors. & $\begin{array}{l}\text { Hand cleaning; } \\
\text { Only essential visits/visitors }\end{array}$ \\
\hline $\begin{array}{l}\text { Keep distance of two metres. Sanitise } \\
\text { hands. Use own equipment only. Do not } \\
\text { attend if positive Covid, have signs of } \\
\text { Covid or been in contact with anyone } \\
\text { with Covid. }\end{array}$ & $\begin{array}{l}\text { Social distancing; } \\
\text { Hand cleaning; } \\
\text { Separate tools; } \\
\text { Isolate if contract COVID, or in contact } \\
\text { with someone with COVID }\end{array}$ \\
\hline $\begin{array}{l}\text { Set times we allowed on yard so all not } \\
\text { there at same time }\end{array}$ & Visit scheduling \\
\hline Once a day one person only & Visit scheduling \\
\hline $\begin{array}{l}\text { It is actually a working farm where I } \\
\text { keep mine and they all live out } 24 / 7 . \\
\text { We have been asked to sanitise and } \\
\text { wash hands as much as possible, to en- } \\
\text { sure we keep each other safe. Also } \\
\text { team up with another livery in case we } \\
\text { need help due to contracting COVID-19. }\end{array}$ & $\begin{array}{l}\text { Hand cleaning; } \\
\text { Isolate if contract COVID, or in contact } \\
\text { with someone with COVID }\end{array}$ \\
\hline $\begin{array}{l}\text { Keep to your own stuff and sanitizer on } \\
\text { arrival. }\end{array}$ & $\begin{array}{l}\text { Separate tools; } \\
\text { Hand cleaning }\end{array}$ \\
\hline Limit to having visitors on yard. & Only essential visits/visitors \\
\hline $\begin{array}{l}\text { Social distance, don't touch peoples } \\
\text { stuff, wash hands on entry, use sani- } \\
\text { tizer, then during lockdowns she shut } \\
\text { the yard then user rotas }\end{array}$ & $\begin{array}{l}\text { Social distancing; } \\
\text { Separate tools; } \\
\text { Hand cleaning; } \\
\text { No owner visits; } \\
\text { Visit scheduling; }\end{array}$ \\
\hline Wear masks, social distancing. & $\begin{array}{l}\text { Face mask; } \\
\text { Social distancing }\end{array}$ \\
\hline $\begin{array}{l}\text { Social Distancing. Riding out with only } 1 \\
\text { other person. Wash hands on arrival } \\
\text { and when leaving. One person in office. } \\
\text { One person in tack room. Gloves to be } \\
\text { worn. Regularly cleaning of toilet. }\end{array}$ & $\begin{array}{l}\text { Social distancing; } \\
\text { Basic riding/no riding; } \\
\text { Hand cleaning; } \\
\text { Gloves }\end{array}$ \\
\hline
\end{tabular}




\begin{tabular}{|c|c|}
\hline $\begin{array}{l}\text { Keep distance from other livery, don't } \\
\text { use others equipment, sanitize and dis- } \\
\text { infect regularly. }\end{array}$ & $\begin{array}{l}\text { Social distancing; } \\
\text { Separate tools; } \\
\text { Disinfection of touchpoints; } \\
\text { Hand cleaning }\end{array}$ \\
\hline $\begin{array}{l}\text { Only primary care givers and Equine } \\
\text { medical professionals allowed on yard } \\
\text { and times of arrival and leaving to be } \\
\text { recorded on app. }\end{array}$ & $\begin{array}{l}\text { Only essential visits/visitors; } \\
\text { Track and Trace app }\end{array}$ \\
\hline $\begin{array}{l}\text { During the first lock down (we haven't } \\
\text { gone into another lock down) } 2 \text { people } \\
\text { riding/at yard at the same time. Book } \\
\text { time slots to ride. They bring horses in } \\
\text { remove any rugs and put them in a sta- } \\
\text { ble (we used } 2 \text { stables that we disin- } \\
\text { fected after). If you use a headcollar } \\
\text { that isn't just for you i.e. workers use it } \\
\text { too dip it in disinfectant. If you have } \\
\text { to use the hose use the (we have four } \\
\text { hoses } 3 \text { around the yard and one by the } \\
\text { tractor to fill it up and wash horses) } \\
\text { tractor hose. }\end{array}$ & $\begin{array}{l}\text { Visit scheduling; } \\
\text { Disinfection of touchpoints }\end{array}$ \\
\hline $\begin{array}{l}\text { hand sanitizer, only } 3 \text { people at the yard } \\
\text { everyone goes up at different times }\end{array}$ & $\begin{array}{l}\text { Hand cleaning; } \\
\text { Visit scheduling }\end{array}$ \\
\hline $\begin{array}{l}\text { Wash hands. Don't bring anyone else } \\
\text { with you. Stay at home if you have } \\
\text { symptoms or are self isolating. Ride out } \\
\text { in 2's. }\end{array}$ & $\begin{array}{l}\text { Hand cleaning; } \\
\text { Only essential visits/visitors; } \\
\text { Isolate if contract COVID, or in contact } \\
\text { with someone with COVID; } \\
\text { Basic riding/no riding }\end{array}$ \\
\hline $\begin{array}{l}\text { No visitors, only owner/immediate } \\
\text { carer. }\end{array}$ & Only essential visits/visitors; \\
\hline $\begin{array}{l}\text { To keep visits to a minimum and no visi- } \\
\text { tors. }\end{array}$ & Only essential visits/visitors \\
\hline $\begin{array}{l}\text { To follow government guidelines on so- } \\
\text { cial distancing and we have a timetable } \\
\text { so not everyone up at the same time. }\end{array}$ & $\begin{array}{l}\text { Social distancing; } \\
\text { Visit scheduling }\end{array}$ \\
\hline $\begin{array}{l}\text { Clear yard rules in line with COVID regu- } \\
\text { lations. Updated weekly along with gov- } \\
\text { ernment guidelines when required. }\end{array}$ & $\begin{array}{l}\text { Social distancing; } \\
\text { Hand cleaning; } \\
\text { Face mask }\end{array}$ \\
\hline $\begin{array}{l}\text { Observe social distancing (marked lines } \\
\text { outside stable area); Use wipes on com- } \\
\text { munal handles, gates, etc. }\end{array}$ & $\begin{array}{l}\text { Social distancing; } \\
\text { Disinfection of touchpoints }\end{array}$ \\
\hline
\end{tabular}




\begin{tabular}{|c|c|}
\hline $\begin{array}{l}\text { Hand sanitizer, no travelling horses off } \\
\text { the yard, keep } 2 \mathrm{~m} \text { apart, no sharing } \\
\text { tools, only one person in feed } \\
\text { room/coffee bothy etc. }\end{array}$ & $\begin{array}{l}\text { Hand cleaning; } \\
\text { Basic riding/no riding; } \\
\text { Social distancing; } \\
\text { Separate tools }\end{array}$ \\
\hline $\begin{array}{l}\text { Separate toilets for yard staff and own- } \\
\text { ers. No congregating in tack room (alt- } \\
\text { hough its huge). Hand sanitiser on the } \\
\text { yard and in the tack room for every- } \\
\text { one's use. I also have my own protocols } \\
\text { as I visit lots of other yards for work and } \\
\text { work for the nhs. Fresh change of } \\
\text { clothes each yard visit, hand sanitiser in } \\
\text { my car used before and after riding. }\end{array}$ & $\begin{array}{l}\text { Social distancing; } \\
\text { Hand cleaning }\end{array}$ \\
\hline Stay $2 m$ apart. & Social distancing \\
\hline $\begin{array}{l}\text { Social distancing maintained, regular } \\
\text { handwashing required when using } \\
\text { shared taps etc and in lockdown allo- } \\
\text { cated time slots for visits. The other } \\
\text { yard is a private yard with only my pony } \\
\text { and another on. During lockdown and } \\
\text { tier } 4 \text { conditions I refrained from visit- } \\
\text { ing and the yard owner cared for pony } \\
\text { unless emergency. }\end{array}$ & $\begin{array}{l}\text { Social distancing; } \\
\text { Hand cleaning; } \\
\text { Visit scheduling; } \\
\text { Only essential visits/visitors }\end{array}$ \\
\hline $\begin{array}{l}\text { No sharing tools. } 1 \text { person per stable. } \\
\text { Gloves and masks on at all times. }\end{array}$ & $\begin{array}{l}\text { Separate tools; } \\
\text { Social distancing; } \\
\text { Gloves; } \\
\text { Face mask }\end{array}$ \\
\hline & No details \\
\hline $\begin{array}{l}\text { Time limit initially on first lockdown } \\
\text { with no riding, washing equipment/taps } \\
\text { down after use }\end{array}$ & $\begin{array}{l}\text { Visit schedulling; } \\
\text { Basic riding/no riding; } \\
\text { Disinfection of touchpoints }\end{array}$ \\
\hline $\begin{array}{l}\text { Only one person allowed per horse dur- } \\
\text { ing lockdown times. No friends/family } \\
\text { during lockdown. Minimise time spent } \\
\text { hanging around on the yard for no good } \\
\text { reason/chat time. Maintain social dis- } \\
\text { tancing. Personally, I don't use } \\
\text { the tea room and take my own water } \\
\text { bottle with me to drink out off. Extra } \\
\text { hand washing. We also filled bot- } \\
\text { tles with disinfectant and regularly } \\
\text { sprayed touch points initially, though } \\
\text { this seems to have tapered off (horse }\end{array}$ & $\begin{array}{l}\text { Social distancing; } \\
\text { Only essential visits/visitors; } \\
\text { Hand cleaning; } \\
\text { Disinfection of touchpoints; } \\
\text { Only essential visits/visitors; } \\
\text { Isolate if contract COVID, or in contact } \\
\text { with someone with COVID }\end{array}$ \\
\hline
\end{tabular}




\begin{tabular}{|c|c|}
\hline $\begin{array}{l}\text { owners did this as their own idea). If an- } \\
\text { yone was told to self-isolate someone } \\
\text { else did their horses and disinterested } \\
\text { their stable/kit etc. Asked not to attend } \\
\text { yard if showing any symptoms or told to } \\
\text { isolate. }\end{array}$ & \\
\hline $\begin{array}{l}\text { Time slots. Wear gloves. Hand sanisiter. } \\
\text { Disinfectant spray. }\end{array}$ & $\begin{array}{l}\text { Visit scheduling; } \\
\text { Gloves; } \\
\text { Hand cleaning; } \\
\text { Disinfection of touchpoints }\end{array}$ \\
\hline $\begin{array}{l}\text { First lockdown, no access to ride. Visit } \\
\text { only to field when horses turned out. To } \\
\text { start with. Transitioned to } 2 \text { only at a } \\
\text { time tied up outside yard to groom and } \\
\text { tack up. Owners kept tack in cars. Back } \\
\text { to normal briefly. During second lock- } \\
\text { down } 3 \text { people on yard at a time using } \\
\text { rota. Same again now. } 2 \text { people only } \\
\text { riding out together. One person in tack } \\
\text { room at a time. }\end{array}$ & $\begin{array}{l}\text { Basic riding/no riding; } \\
\text { Visit scheduling; }\end{array}$ \\
\hline $\begin{array}{l}\text { Lockdown 1: no access. Lockdown 2: ac- } \\
\text { cess but obey hands face space. Tier } 4 \text { : } \\
\text { must wear face mask on yard. }\end{array}$ & $\begin{array}{l}\text { Complete yard lockdown; } \\
\text { No owner visits; } \\
\text { Hand cleaning; } \\
\text { Social distancing; } \\
\text { Face mask }\end{array}$ \\
\hline $\begin{array}{l}\text { Limited currently (in first lockdown in } \\
\text { spring there were time slots to manage } \\
\text { numbers) - basically keep your distance, } \\
\text { one at a time in tack room, liveries and } \\
\text { equine professionals only on the yard. }\end{array}$ & $\begin{array}{l}\text { Visit scheduling; } \\
\text { Only essential visits/visitors; } \\
\text { Social distancing }\end{array}$ \\
\hline $\begin{array}{l}\text { Only } 2 \text { people on yard at any one time. } \\
\text { Lots of sanitiser everywhere }\end{array}$ & $\begin{array}{l}\text { Visit scheduling; } \\
\text { Hand cleaning }\end{array}$ \\
\hline $\begin{array}{l}\text { Face mask/ one way system/ hand sani- } \\
\text { tizer/ booked time slots/ distancing } \\
\text { from people/ only be involved with } \\
\text { your horse and then go home. }\end{array}$ & $\begin{array}{l}\text { Face mask; } \\
\text { Hand cleaning; } \\
\text { Social distancing; } \\
\text { Only essential visits/visitors } \\
\text { Visit scheduling }\end{array}$ \\
\hline $\begin{array}{l}\text { Social distancing and horse care rota to } \\
\text { avoid unnecessary contact }\end{array}$ & $\begin{array}{l}\text { Social distancing; } \\
\text { Visit scheduling }\end{array}$ \\
\hline $\begin{array}{l}\text { College standards and riding school } \\
\text { standards }\end{array}$ & No details \\
\hline
\end{tabular}




\begin{tabular}{|c|c|}
\hline $\begin{array}{l}\text { Time slots, Face masks to be worn and } \\
\text { hand sanitizer to be used that's on the } \\
\text { gate. }\end{array}$ & $\begin{array}{l}\text { Visit scheduling; } \\
\text { Face mask; } \\
\text { Hand cleaning }\end{array}$ \\
\hline $\begin{array}{l}\text { No going into other barns where your } \\
\text { horse isn't stabled, wearing masks, no } \\
\text { sharing of the school, no visitors other } \\
\text { than farrier, vet etc }\end{array}$ & $\begin{array}{l}\text { Face mask; } \\
\text { Social distancing; } \\
\text { Only essential visit/visitors }\end{array}$ \\
\hline $\begin{array}{l}\text { Use own tools. Stay in own block. Only } \\
2 \text { in indoor at anyone time. }\end{array}$ & $\begin{array}{l}\text { Separate tools; } \\
\text { Social distancing }\end{array}$ \\
\hline $\begin{array}{l}\text { Social distancing, part of the yard is } \\
\text { now out of bounds (near to owners } \\
\text { house). During the second national } \\
\text { lockdown (Nov 2020) they asked us not } \\
\text { to travel off the yard with the horses for } \\
\text { lessons, hacking etc }\end{array}$ & $\begin{array}{l}\text { Social distancing; } \\
\text { Basic riding/no riding }\end{array}$ \\
\hline $\begin{array}{l}\text { Face masks to be worn at all times. So- } \\
\text { cial distancing to be put in practice. } \\
\text { Time slots were applicable during the } \\
\text { first full lock down. }\end{array}$ & $\begin{array}{l}\text { Face mask; } \\
\text { Social distancing; } \\
\text { Visit scheduling }\end{array}$ \\
\hline Social Distancing, mask. & $\begin{array}{l}\text { Social distancing; } \\
\text { Face mask }\end{array}$ \\
\hline $\begin{array}{l}\text { No lessons. No outsiders visiting only } \\
\text { vets, farrier etc. }\end{array}$ & $\begin{array}{l}\text { Basic riding/no riding; } \\
\text { Only essential visit/visitors }\end{array}$ \\
\hline $\begin{array}{l}2 \text { metre ruling - hand sanitising (We are } \\
\text { on a large yard with plenty of space). } \\
\text { Specific areas for individuals to keep } \\
\text { their equipment). }\end{array}$ & $\begin{array}{l}\text { Social distancing; } \\
\text { Hand cleaning }\end{array}$ \\
\hline $\begin{array}{l}\text { To go at alternate times. Use own } \\
\text { equipment and drinking vessels }\end{array}$ & $\begin{array}{l}\text { Visit scheduling } \\
\text { Separate tools }\end{array}$ \\
\hline $\begin{array}{l}\text { Keeping your own drinking utensils, } \\
\text { washing everything up thoroughly. Eve- } \\
\text { ryone is socially distancing. }\end{array}$ & $\begin{array}{l}\text { Separate tools; } \\
\text { Social distancing; } \\
\text { Disinfection of touchpoints }\end{array}$ \\
\hline $\begin{array}{l}\text { Hand sanitiser at gate and on yard also } \\
\text { keep } 2 \mathrm{~m} \text { apart. }\end{array}$ & $\begin{array}{l}\text { Hand cleaning; } \\
\text { Social distancing }\end{array}$ \\
\hline General sanitising of equipment. & Disinfection of touchpoints \\
\hline $\begin{array}{l}\text { Use your own equipment. Hand gel for } \\
\text { before and after coming/leaving yard. } \\
\text { Keep } 2 \mathrm{~m} \text { distance from each other. }\end{array}$ & $\begin{array}{l}\text { Separate tools; } \\
\text { Hand cleaning; } \\
\text { Social distancing } \\
\end{array}$ \\
\hline $\begin{array}{l}2 \mathrm{~m} \text { social distancing, hand sanitizer } \\
\text { available and only } 1 \text { person from your } \\
\text { family to attend yard with you. }\end{array}$ & $\begin{array}{l}\text { Social distancing; } \\
\text { Hand cleaning; } \\
\text { Only essential visits/visitors }\end{array}$ \\
\hline
\end{tabular}




\begin{tabular}{|c|c|}
\hline $\begin{array}{l}\text { Wear a mask when around others, use } \\
\text { only your own equipment. }\end{array}$ & $\begin{array}{l}\text { Face mask; } \\
\text { Separate tools }\end{array}$ \\
\hline $\begin{array}{l}\text { Just the general hands face space, to } \\
\text { notify her of external visitors (physio } \\
\text { etc), and wipe down surfaces after use } \\
\text { like the school door. }\end{array}$ & $\begin{array}{l}\text { Hand cleaning; } \\
\text { Face mask; } \\
\text { Social distancing; } \\
\text { Only essential visits/visitors; } \\
\text { Disinfection of touchpoints }\end{array}$ \\
\hline $\begin{array}{l}\text { Distancing at all times. Not sharing } \\
\text { equipment. No extra faffing (no } \\
\text { standing round to chat / have cups of } \\
\text { tea etc). }\end{array}$ & $\begin{array}{l}\text { Social distancing; } \\
\text { Separate tools; }\end{array}$ \\
\hline $\begin{array}{l}\text { Hand Sanitizer. } 2 \text { m space. } 2 \text { people only } \\
\text { in tack room. } 2 \text { people only in feed } \\
\text { room. }\end{array}$ & $\begin{array}{l}\text { Hand cleaning; } \\
\text { Social distancing; }\end{array}$ \\
\hline $\begin{array}{l}\text { Use hand sanitizer. No sharing tools. } \\
\text { Face coverings in the barn. Stay in your } \\
\text { own areas. }\end{array}$ & $\begin{array}{l}\text { Hand cleaning; } \\
\text { Separate tools; } \\
\text { Face mask; } \\
\text { Social distancing }\end{array}$ \\
\hline Social distancing & Social distancing \\
\hline $\begin{array}{l}\text { Only } 2 \text { in area at a time. Keep distance } \\
\text { in hay barn, tackroom etc. }\end{array}$ & Social distancing \\
\hline $\begin{array}{l}\text { Communal area out of bounds. Only } \\
\text { liveries allowed up. Do horse and go } \\
\text { home. }\end{array}$ & $\begin{array}{l}\text { Only essential visits/visitors; } \\
\text { Social distancing }\end{array}$ \\
\hline $\begin{array}{l}\text { Only one person at time, full cleansing, } \\
\text { Masks, sanitise all areas and boots so- } \\
\text { cial distancing in place, any symptoms } \\
\text { the horses will be cared for. Care and } \\
\text { exercise only. Due to the work I do my } \\
\text { horses are being looked after until the } \\
\text { restrictions ease. }\end{array}$ & $\begin{array}{l}\text { Social distancing; } \\
\text { Face mask; } \\
\text { Disinfection of touchpoints; } \\
\text { Only essential visits/visitors; } \\
\text { Isolate if contract COVID, or in contact } \\
\text { with someone with COVID }\end{array}$ \\
\hline $\begin{array}{l}\text { Social distancing. Don't use other peo- } \\
\text { ple things. Masks if more than } 4 \text { people. } \\
\text { Wash hands and hand sanitizer. No } \\
\text { hanging about unnecessary. }\end{array}$ & $\begin{array}{l}\text { Social distancing; } \\
\text { Separate tools; } \\
\text { Face mask; } \\
\text { Hand cleaning; } \\
\text { Only essential visits/visitors }\end{array}$ \\
\hline $\begin{array}{l}\text { At the start of the pandemic we were } \\
\text { told to only stay at the yard as long as } \\
\text { was needed to see to your horse and } \\
\text { then leave ASAP, and we had to wear } \\
\text { gloves. That seemed to stop in the } \\
\text { summer and nothing gets said now. }\end{array}$ & $\begin{array}{l}\text { Only essential visits/visitors; } \\
\text { Gloves }\end{array}$ \\
\hline
\end{tabular}




\begin{tabular}{|c|c|}
\hline $\begin{array}{l}\text { Wash hands when entering / exiting } \\
\text { yard, social distancing. }\end{array}$ & $\begin{array}{l}\text { Hand cleaning; } \\
\text { Social distancing }\end{array}$ \\
\hline $\begin{array}{l}\text { Social distance at all times, don't bring } \\
\text { people with you to the yard when un- } \\
\text { necessary obviously vets/instructors al- } \\
\text { lowed when the broader covid rules al- } \\
\text { lowed. }\end{array}$ & $\begin{array}{l}\text { Social distancing; } \\
\text { Only essential visits/visitors; }\end{array}$ \\
\hline $\begin{array}{l}\text { Wipe all shared equipment with the dis- } \\
\text { infectant provided. Use hand gel pro- } \\
\text { vided. Do not attend if experienced } \\
\text { symptoms. Set times to attend the } \\
\text { yard with same people attending at } \\
\text { same times. Social distancing in place. }\end{array}$ & $\begin{array}{l}\text { Disinfection of touchpoints; } \\
\text { Hand cleaning; } \\
\text { Isolate if contract COVID, or in contact } \\
\text { with someone with COVID; } \\
\text { Visit scheduling; } \\
\text { Social distancing }\end{array}$ \\
\hline $\begin{array}{l}\text { Wear a mask. Use own halter to bring in } \\
\text { and turn out your horse. Social distanc- } \\
\text { ing when in the Clubhouse. }\end{array}$ & $\begin{array}{l}\text { Face mask; } \\
\text { Separate tools; } \\
\text { Social distancing }\end{array}$ \\
\hline $\begin{array}{l}\text { Masks, wipe tack after, no friends or } \\
\text { other family members, }\end{array}$ & $\begin{array}{l}\text { Face mask; } \\
\text { Disinfection of touchpoints; } \\
\text { Only essential visits/visitors }\end{array}$ \\
\hline $\begin{array}{l}\text { No household mixing. My horse is in } \\
\text { tier } 4 \text { and I'm in tier } 3 .\end{array}$ & Social distancing \\
\hline $\begin{array}{l}\text { Farmer is shielding due to cancer so dis- } \\
\text { tancing and disinfecting any shared } \\
\text { items after use. I am also in the at risk } \\
\text { group so being very careful. }\end{array}$ & $\begin{array}{l}\text { Social distancing; } \\
\text { Disinfection of touchpoints }\end{array}$ \\
\hline $\begin{array}{l}\text { Two hour attendance slots, not over } \\
\text { lapping with other liveries. }\end{array}$ & Visit scheduling \\
\hline $\begin{array}{l}\text { Social distancing, mask wearing in the } \\
\text { office. Lessons currently limited per } \\
\text { BHS guidance. }\end{array}$ & $\begin{array}{l}\text { Social distancing; } \\
\text { Face mask; } \\
\text { Basic riding/no riding } \\
\end{array}$ \\
\hline $\begin{array}{l}\text { Space out times for when liveries come } \\
\text { and see their horses, only } 2 \text { liveries al- } \\
\text { lowed in the indoor/outdoor school at } \\
\text { any one time, only } 2 \text { people per horse } \\
\text { to come to the yard and wash hands } \\
\text { and social distance }\end{array}$ & $\begin{array}{l}\text { Visit scheduling; } \\
\text { Hand cleaning; } \\
\text { Social distancing }\end{array}$ \\
\hline No sharing equipment & Separate tools \\
\hline $\begin{array}{l}\text { Social distancing. In first lockdown time } \\
\text { slots once a day but not now. }\end{array}$ & $\begin{array}{l}\text { Social distancing; } \\
\text { Visit scheduling }\end{array}$ \\
\hline Social distancing & Social distancing \\
\hline
\end{tabular}




\begin{tabular}{|c|c|}
\hline $\begin{array}{l}\text { Masks. Distancing. Can't stay at the } \\
\text { yard all day. No mixing households } \\
\text { when riding in the indoor. }\end{array}$ & $\begin{array}{l}\text { Face mask; } \\
\text { Social distancing; } \\
\text { Only essential visits/visitors; } \\
\text { Bubbles }\end{array}$ \\
\hline $\begin{array}{l}\text { Socially distance, hand-wash. If you } \\
\text { have any symptoms, stay away. Had } \\
\text { time slots for visits to reduce number of } \\
\text { people on yard at any one time, assis- } \\
\text { tance with bring in and turnout. }\end{array}$ & $\begin{array}{l}\text { Social distancing; } \\
\text { Hand cleaning; } \\
\text { Isolate if contract COVID, or in contact } \\
\text { with someone with COVID; } \\
\text { Visit scheduling }\end{array}$ \\
\hline $\begin{array}{l}2 \text { meters apart. Don't gather together. } \\
\text { Wash hands frequently. }\end{array}$ & $\begin{array}{l}\text { Social distancing; } \\
\text { Hand cleaning }\end{array}$ \\
\hline $\begin{array}{l}\text { Time slots for visits, limit time spent on } \\
\text { yard to necessary to carry out proper } \\
\text { care, gloves at all times. }\end{array}$ & $\begin{array}{l}\text { Visit scheduling; } \\
\text { Gloves }\end{array}$ \\
\hline $\begin{array}{l}\text { There have been loads - following what } \\
\text { the government said. First lockdown we } \\
\text { were unable to ride at first, we had } \\
\text { time slots to care for our horses, disin- } \\
\text { fectant to spray on locks / handles, our } \\
\text { own tools etc. Currently the rules are } \\
\text { only } 2 \text { can ride together, only } 1 \text { to } 1 \\
\text { training, no more than } 1 \text { person in any } \\
\text { "indoor" space (tack, feed room etc). } \\
\text { We are not allowed to congregate to } \\
\text { drink tea / socialise, we cannot travel } \\
\text { outside of our own tiers to compete. }\end{array}$ & $\begin{array}{l}\text { Basic riding/no riding; } \\
\text { Visit scheduling; } \\
\text { Disinfection of touchpoints; } \\
\text { Social distancing }\end{array}$ \\
\hline $\begin{array}{l}\text { Social distance - at gate is hand sani- } \\
\text { tizer and code to log on -( all liveries are } \\
\text { tier } 3 \text { ) only go at timetabled times to re- } \\
\text { duce numbers on yard. }\end{array}$ & $\begin{array}{l}\text { Social distancing; } \\
\text { Hand cleaning; } \\
\text { Visit scheduling }\end{array}$ \\
\hline $\begin{array}{l}\text { Was hands on arrival. Disinfect tools af- } \\
\text { ter use. No hanging around for a chat. } \\
1 \text { person in tack room at a time. Only } \\
\text { owners/riders allowed in the stable } \\
\text { area. }\end{array}$ & $\begin{array}{l}\text { Hand cleaning; } \\
\text { Disinfection of touchpoints; } \\
\text { Only essential visits/visitors; } \\
\text { Social distancing }\end{array}$ \\
\hline $\begin{array}{l}\text { No outside visitors other than vets farri- } \\
\text { ers etc. No outside trainers or instruc- } \\
\text { tors or bringing friends etc to the yard. }\end{array}$ & Only essential visits/visitors \\
\hline One on the yard at a time (3 liveries) & Visit scheduling \\
\hline $\begin{array}{l}\text { We have to sign a book to say we've } \\
\text { been there. The field owner lives adja- } \\
\text { cent to the field and runs a B\&B. We } \\
\text { can access the } 18 \text { acre field from tne }\end{array}$ & Sign in/out; \\
\hline
\end{tabular}




\begin{tabular}{|c|c|}
\hline $\begin{array}{l}\text { B\&B car park or from a gate on the top } \\
\text { lane half a mile away from the house. } \\
\text { This means we have to go to the yard to } \\
\text { sign the book even if we're feeding the } \\
\text { horses at the top gate and wouldn't } \\
\text { normally go to the house /yard at all. } \\
\text { My horses are } 2 \text { of } 7 \text { horses in the field, } \\
\text { there are } 5 \text { owners. }\end{array}$ & \\
\hline $\begin{array}{l}\text { Selected time slots to arrive to see to } \\
\text { your own horses so no households } \\
\text { mixed. }\end{array}$ & Visit scheduling; \\
\hline $\begin{array}{l}\text { We social distance from one another if } \\
\text { we are all up together. }\end{array}$ & Social distancing \\
\hline Masks worn within inside areas. & Face mask \\
\hline \multirow[t]{2}{*}{$\begin{array}{l}\text { No visitors, no bareback riding or jump- } \\
\text { ing during the first nationwide lock- } \\
\text { down. }\end{array}$} & $\begin{array}{l}\text { Only essential visits/visitors: } \\
\text { Basic riding/no riding }\end{array}$ \\
\hline & No details \\
\hline $\begin{array}{l}\text { We don't use each other's stuff and we } \\
\text { don't hang around talking. Rules are } \\
\text { pretty relaxed as we don't all go up at } \\
\text { the same time of day. }\end{array}$ & $\begin{array}{l}\text { Separate tools; } \\
\text { Social distancing; } \\
\text { Visit scheduling }\end{array}$ \\
\hline
\end{tabular}

Appendix C1: Details of the rules "imposed by horse owner [by you]" at respondent yards and categorization of the answer 


\begin{tabular}{|c|c|}
\hline Respondent answer & $\begin{array}{l}\text { Categorisation of } \\
\text { answer }\end{array}$ \\
\hline $\begin{array}{l}\text { Passers-by to stay } 6 \text { feet from gate and boundary fence. No } \\
\text { feeding the ponies or touching them. }\end{array}$ & $\begin{array}{l}\text { Social distancing; } \\
\text { No touching of } \\
\text { horses by strangers }\end{array}$ \\
\hline $\begin{array}{l}\text { Separate tools - use own only. Wipe gate handles etc after use. } \\
\text { Keep distance }\end{array}$ & $\begin{array}{l}\text { Separate tools; } \\
\text { Disinfection of } \\
\text { touchpoints }\end{array}$ \\
\hline $\begin{array}{l}\text { If pony sharer's come to the yard then my family keeps away } \\
\text { from the yard. }\end{array}$ & Social distancing \\
\hline Social distancing & Social distancing \\
\hline No extra people. Maintain social distance etc & $\begin{array}{l}\text { Social distancing } \\
\text { Only essential vis- } \\
\text { its/visitors }\end{array}$ \\
\hline $\begin{array}{l}\text { I'm at a yard with a close friend so it's only } 3 \text { of us attending } \\
\text { the horses. During restrictions we have made sure there's only } \\
2 \text { of us there at a time. Maintained social distancing on the } \\
\text { yard and cleaned and antibac sprayed all touch points on the } \\
\text { yard (taps, feed room door handles etc). }\end{array}$ & $\begin{array}{l}\text { Visit scheduling; } \\
\text { Social distancing; } \\
\text { Disinfection of } \\
\text { touchpoints }\end{array}$ \\
\hline $\begin{array}{l}\text { Private yard that only I use with my children. Only visitors are } \\
\text { farrier/vet when needed }\end{array}$ & $\begin{array}{l}\text { Only essential vis- } \\
\text { its/visitors }\end{array}$ \\
\hline Social distancing & Social distancing \\
\hline No one allowed to visit when on full lockdown or Tier 4. & No owner visits \\
\hline $\begin{array}{l}\text { Regular hand sanitiser, distance, separate tools for owners, no } \\
\text { trainers }\end{array}$ & $\begin{array}{l}\text { Hand cleaning; } \\
\text { Social distancing; } \\
\text { Separate tools; } \\
\text { Only essential vis- } \\
\text { its/visitors }\end{array}$ \\
\hline $\begin{array}{l}\text { Only owners to do their horses. No extra visitors. Hand wash } \\
\text { before and after leaving or when used taps or gate to arena }\end{array}$ & $\begin{array}{l}\text { Only essential vis- } \\
\text { its/visitors; } \\
\text { Hand cleaning }\end{array}$ \\
\hline No visitors & No owner visits \\
\hline Social distancing & Social distancing \\
\hline No one else gets to come into my yard. & $\begin{array}{l}\text { Complete yard } \\
\text { lockdown }\end{array}$ \\
\hline $\begin{array}{l}\text { Socially distance and keep all doors open to allow fresh air in } \\
\text { when on the yard. }\end{array}$ & $\begin{array}{l}\text { Social distancing; } \\
\text { Windows open in } \\
\text { inside areas }\end{array}$ \\
\hline $\begin{array}{l}\text { Keep out, It's my ground, I have electric fencing inside a pad- } \\
\text { locked gate }\end{array}$ & $\begin{array}{l}\text { Complete yard } \\
\text { lockdown }\end{array}$ \\
\hline $\begin{array}{l}\text { Gel and feet dip at gate and before leaving - basically I'm treat- } \\
\text { ing as human version of strangles }\end{array}$ & $\begin{array}{l}\text { Hand cleaning; } \\
\text { Foot dip }\end{array}$ \\
\hline
\end{tabular}




\begin{tabular}{|c|c|}
\hline $\begin{array}{l}\text { As I'm the only one there I'm fine } 90 \% \text { of the time. It's if I have } \\
\text { farrier or vet. I wear a mask and sanitise everything }\end{array}$ & $\begin{array}{l}\text { Face mask; } \\
\text { Cleaning touch- } \\
\text { points }\end{array}$ \\
\hline $\begin{array}{l}\text { We do abide by Covid rules. i.e., We don't see anyone when } \\
\text { we are there. We don't share equipment, If we were unfortu- } \\
\text { nate to catch COVID we have a backup plan with my friend - } \\
\text { who's farm our horse is stabled at - where she would take over } \\
\text { the care. }\end{array}$ & $\begin{array}{l}\text { Separate tools; } \\
\text { Social distancing; } \\
\text { Isolate if contract } \\
\text { COVID, or in con- } \\
\text { tact with someone } \\
\text { with COVID }\end{array}$ \\
\hline $\begin{array}{l}\text { No sharing of tools Avoid visiting if unwell/ isolating due to } \\
\text { partner test - offered free full livery to encourage compliance } \\
\text { with this. }\end{array}$ & $\begin{array}{l}\text { Separate tools; } \\
\text { Isolate if contract } \\
\text { COVID, or in con- } \\
\text { tact with someone } \\
\text { with COVID }\end{array}$ \\
\hline I go when no one else is there and use hand sanitizer & $\begin{array}{l}\text { Social distancing; } \\
\text { Hand cleaning }\end{array}$ \\
\hline Friends who come to ride horse can no longer & $\begin{array}{l}\text { Only essential vis- } \\
\text { its/visitors }\end{array}$ \\
\hline \multicolumn{2}{|l|}{ Common sense } \\
\hline $\begin{array}{l}\text { No visitors just horse owner, sanitise hands and handles bolts } \\
\text { etc on gates and doors }\end{array}$ & $\begin{array}{l}\text { Only essential vis- } \\
\text { its/visitors; } \\
\text { Hand cleaning; } \\
\text { Disinfection of } \\
\text { touchpoints }\end{array}$ \\
\hline $\begin{array}{l}\text { Only I open gates. Treatment visits must maintain distance } \\
\text { where possible. Disinfectant boot wash. Anti bacterial wipes } \\
\text { and gel must be used }\end{array}$ & $\begin{array}{l}\text { Social distancing; } \\
\text { Foot dip; } \\
\text { Disinfection of } \\
\text { touchpoints; } \\
\text { Hand cleaning }\end{array}$ \\
\hline Social distancing. & Social distancing \\
\hline We clean/sanitise everything used. We stay 2 metres apart & $\begin{array}{l}\text { Disinfection of } \\
\text { touchpoints; } \\
\text { Social distancing }\end{array}$ \\
\hline $\begin{array}{l}\text { If myself or my daughter have been in contact with someone } \\
\text { who has tested positive with covid we will self isolate }\end{array}$ & $\begin{array}{l}\text { Isolate if contract } \\
\text { COVID, or in con- } \\
\text { tact with someone } \\
\text { with COVID }\end{array}$ \\
\hline Own yard no-one else there & $\begin{array}{l}\text { Complete yard } \\
\text { lockdown }\end{array}$ \\
\hline Just my self and family on the yard. & $\begin{array}{l}\text { Complete yard } \\
\text { lockdown }\end{array}$ \\
\hline
\end{tabular}




\begin{tabular}{|c|c|}
\hline $\begin{array}{l}\text { Usually I am the only person who visits. If someone else has to } \\
\text { do my horses then we sterilise all door handles and equipment } \\
\text { that we touch when we handover to next person }\end{array}$ & $\begin{array}{l}\text { Disinfection of } \\
\text { touchpoints; }\end{array}$ \\
\hline $\begin{array}{l}\text { Social distancing. Staggered visit times. No visiting yard if self } \\
\text { isolating. No sharing of tools. }\end{array}$ & $\begin{array}{l}\text { Social distancing; } \\
\text { Visit scheduling; } \\
\text { Isolate if contract } \\
\text { COVID, or in con- } \\
\text { tact with someone } \\
\text { with COVID; } \\
\text { Separate tools }\end{array}$ \\
\hline $\begin{array}{l}\text { Social distancing, washing hands in staff room, seating outside } \\
\text { only }\end{array}$ & $\begin{array}{l}\text { Social distancing; } \\
\text { Hand cleaning; } \\
\text { Sitting outside }\end{array}$ \\
\hline \multicolumn{2}{|l|}{ No detail provided } \\
\hline Only professionals allowed on yard & $\begin{array}{l}\text { Only essential vis- } \\
\text { its/visitors; }\end{array}$ \\
\hline $\begin{array}{l}\text { Sanitise everything. Wear facemasks. Wear gloves. No extra } \\
\text { people to the yard unless necessary }\end{array}$ & $\begin{array}{l}\text { Disinfect touch- } \\
\text { points; } \\
\text { Face mask; } \\
\text { Gloves; } \\
\text { Only essential vis- } \\
\text { its/visitors; }\end{array}$ \\
\hline $\begin{array}{l}\text { We don't let anyone else on the yard and we stay in our bub- } \\
\text { ble. I have kids that loan ponies and parents are not permitted }\end{array}$ & $\begin{array}{l}\text { Complete yard } \\
\text { lockdown }\end{array}$ \\
\hline $\begin{array}{l}\text { No coming if sick. Keep social distancing. Clean all areas regu- } \\
\text { larly }\end{array}$ & $\begin{array}{l}\text { Isolate if contract } \\
\text { COVID, or in con- } \\
\text { tact with someone } \\
\text { with COVID; } \\
\text { Social distancing; } \\
\text { Disinfection of } \\
\text { touchpoints }\end{array}$ \\
\hline $\begin{array}{l}\text { Hand Sanitiser in use for visitors. Distance maintained. Visitors } \\
\text { limited to } 1 \text { rider (the same throughout the year) plus the pro- } \\
\text { fessionals (farrier, vet etc) }\end{array}$ & $\begin{array}{l}\text { Hand cleaning; } \\
\text { Social distancing; } \\
\text { Only essential vis- } \\
\text { its/visitors; }\end{array}$ \\
\hline No visitors, hand sanitise etc & $\begin{array}{l}\text { Only essential vis- } \\
\text { its/visitors; } \\
\text { Hand cleaning; }\end{array}$ \\
\hline $\begin{array}{l}\text { Face masks, gloves, only use your own equipment. sanitiser } \\
\text { and anti viral surface cleaner available in tackroom. staggered }\end{array}$ & $\begin{array}{l}\text { Face mask; } \\
\text { Gloves; }\end{array}$ \\
\hline
\end{tabular}




\begin{tabular}{|c|c|}
\hline $\begin{array}{l}\text { times to do your horses to minimise contact. no unnecessary } \\
\text { visitors to the yard }\end{array}$ & $\begin{array}{l}\text { Separate tools; } \\
\text { Hand cleaning; } \\
\text { Disinfection of } \\
\text { touchpoints; } \\
\text { Visit scheduling; } \\
\text { Only essential vis- } \\
\text { its/visitors; }\end{array}$ \\
\hline $\begin{array}{l}\text { Take temp when arrive. Use the hand sanitizer when you ar- } \\
\text { rive at the gate. Don't hang around on the yard. Wear a mask, } \\
\text { and keep } 1 \mathrm{mtr} \text { at least away from anyone else. }\end{array}$ & $\begin{array}{l}\text { Temperature } \\
\text { check; } \\
\text { Hand cleaning; } \\
\text { Face mask; } \\
\text { Only essential vis- } \\
\text { its/visitors; } \\
\text { Social distancing }\end{array}$ \\
\hline No visitors, don't hang around, do and go & $\begin{array}{l}\text { Only essential vis- } \\
\text { its/visitors; }\end{array}$ \\
\hline $\begin{array}{l}\text { Only essential people to enter the yard. No tool sharing/bor- } \\
\text { rowing. Wipe down communal areas (kettle, handles etc) with } \\
\text { antibac wipes. Social distance the best you can }\end{array}$ & $\begin{array}{l}\text { Only essential vis- } \\
\text { its/visitors; } \\
\text { Separate tools; } \\
\text { Disinfection of } \\
\text { touchpoints; } \\
\text { Social distancing }\end{array}$ \\
\hline $\begin{array}{l}\text { Keeping } 2 \text { metre distance from anyone. Cleaning hands on arri- } \\
\text { val/departure. Hand cleansing gel available always. }\end{array}$ & $\begin{array}{l}\text { Social distancing; } \\
\text { Hand cleaning }\end{array}$ \\
\hline \multicolumn{2}{|l|}{ No detail provided } \\
\hline $\begin{array}{l}\text { Strict social distancing. Allocated time slots for full livery horse } \\
\text { owners }\end{array}$ & $\begin{array}{l}\text { Social distancing; } \\
\text { Visit scheduling }\end{array}$ \\
\hline Only see to your horses no travelling & $\begin{array}{l}\text { Only essential vis- } \\
\text { its/visitors; }\end{array}$ \\
\hline $\begin{array}{l}\text { We all just follow government regulations and keep our dis- } \\
\text { tance from each other }\end{array}$ & Social distancing \\
\hline I have no livery's so only me so no rules & $\begin{array}{l}\text { Complete yard } \\
\text { lockdown }\end{array}$ \\
\hline As I am on my own I follow my own rules & $\begin{array}{l}\text { Complete yard } \\
\text { lockdown }\end{array}$ \\
\hline $\begin{array}{l}\text { No competition outings. Only } 3 \text { riders from our village, only } \\
\text { outside no physical contact with residents }\end{array}$ & $\begin{array}{l}\text { Social distancing; } \\
\text { Basic riding /no rid- } \\
\text { ing }\end{array}$ \\
\hline Follow strict hygiene as if we had strangled around the area. & $\begin{array}{l}\text { Disinfection of } \\
\text { touchpoints }\end{array}$ \\
\hline $\begin{array}{l}\text { Social distancing at all times. No sharing of equipment. Sanitize } \\
\text { on and off the yard }\end{array}$ & $\begin{array}{l}\text { Social distancing; } \\
\text { Separate tools; }\end{array}$ \\
\hline
\end{tabular}




\begin{tabular}{|c|c|}
\hline & Hand cleaning \\
\hline $\begin{array}{l}\text { No visitors unless for equine health, i.e., vet, farrier, hay deliv- } \\
\text { ery }\end{array}$ & $\begin{array}{l}\text { Only essential vis- } \\
\text { its/visitors; }\end{array}$ \\
\hline Social distancing and all equipment swabbed down & $\begin{array}{l}\text { Social distancing; } \\
\text { Disinfection of } \\
\text { touchpoints }\end{array}$ \\
\hline No one is allowed at the field & $\begin{array}{l}\text { Complete yard } \\
\text { lockdown }\end{array}$ \\
\hline $\begin{array}{l}\text { We feed the horses at separate times, and limit occasions } \\
\text { when I meet my livery owner for major field repairs. }\end{array}$ & Visit scheduling \\
\hline \multicolumn{2}{|l|}{ No detail provided } \\
\hline $\begin{array}{l}\text { Wearing of masks in enclosed barn, no other persons on yard } \\
\text { other than horse owners/sharers, have sanitizer on yard }\end{array}$ & $\begin{array}{l}\text { Face mask; } \\
\text { Only essential vis- } \\
\text { its/visitors; } \\
\text { Hand cleaning }\end{array}$ \\
\hline Only us to attend the yard (me and hubby) & $\begin{array}{l}\text { Complete yard } \\
\text { lockdown }\end{array}$ \\
\hline $\begin{array}{l}\text { The toilet was locked and staggered times for people to do } \\
\text { their horses }\end{array}$ & $\begin{array}{l}\text { Yard facilities shut; } \\
\text { Visit scheduling }\end{array}$ \\
\hline $\begin{array}{l}\text { It's just me and my horses on the yard. Only me my daughter } \\
\text { and my husband visit and essential visits from equine profes- } \\
\text { sionals. I am on the extremely clinically vulnerable list so fol- } \\
\text { low all the government guidelines. }\end{array}$ & $\begin{array}{l}\text { Complete yard } \\
\text { lockdown; } \\
\text { Only essential vis- } \\
\text { its/visitors; }\end{array}$ \\
\hline Cleaning of gates-only me and one other person there & $\begin{array}{l}\text { Disinfection of } \\
\text { touchpoints; } \\
\text { Social distancing } \\
\end{array}$ \\
\hline Only us allowed on the yard & $\begin{array}{l}\text { Complete yard } \\
\text { lockdown }\end{array}$ \\
\hline \multicolumn{2}{|l|}{ No detail provided } \\
\hline $\begin{array}{l}\text { No jumping during first lockdown, try to choose different times } \\
\text { to be at yard, keeping tack out of house to avoid people going } \\
\text { into house unnecessarily. }\end{array}$ & $\begin{array}{l}\text { Basic riding/no rid- } \\
\text { ing; } \\
\text { Visit scheduling; }\end{array}$ \\
\hline Stay safe, stay apart & Social distancing \\
\hline $\begin{array}{l}\text { Any visitors keep minimum of } 2 \text { meters distance. Now we are } \\
\text { in tier } 4 \text { no visitors and only family on yard. }\end{array}$ & $\begin{array}{l}\text { Social distancing; } \\
\text { Only essential vis- } \\
\text { its/visitors; }\end{array}$ \\
\hline $\begin{array}{l}\text { No contact with owners of property, all communications done } \\
\text { over the phone or yelled across the field lol }\end{array}$ & Social distancing \\
\hline $\begin{array}{l}\text { Essential visitors only. No gathering outside of national CV19 } \\
\text { rules }\end{array}$ & $\begin{array}{l}\text { Complete yard } \\
\text { lockdown }\end{array}$ \\
\hline
\end{tabular}




\begin{tabular}{|c|c|}
\hline No one comes to yard & $\begin{array}{l}\text { Complete yard } \\
\text { lockdown }\end{array}$ \\
\hline $\begin{array}{l}\text { Restricted visits booked so no one crosses over. Good bio se- } \\
\text { curity }\end{array}$ & $\begin{array}{l}\text { Visit scheduling; } \\
\text { Disinfection of } \\
\text { touchpoints }\end{array}$ \\
\hline \multicolumn{2}{|l|}{ No detail provided } \\
\hline $\begin{array}{l}\text { No one is to come onto the yard unless vet or farrier. My par- } \\
\text { ents live at my yard. So we keep away from each other. }\end{array}$ & $\begin{array}{l}\text { Only essential vis- } \\
\text { its/visitors; } \\
\text { Social distancing }\end{array}$ \\
\hline To exercise horses then leave & $\begin{array}{l}\text { Only essential vis- } \\
\text { its/visitors; }\end{array}$ \\
\hline No one in house, use own tools own wheelbarrow and fork & Separate tools \\
\hline $\begin{array}{l}\text { Don't touch my stuff or others stuff, yard is massive so not } \\
\text { near each other prob about } 30 \mathrm{ft} \text { away from each other so } \\
\text { that's not an issue } n \text { we all go diff times but do see each other } \\
\text { daily at yard }\end{array}$ & $\begin{array}{l}\text { Separate tools; } \\
\text { Social distancing; } \\
\text { Visit scheduling }\end{array}$ \\
\hline I'm on a private yard. No other visitors are coming on & $\begin{array}{l}\text { Complete yard } \\
\text { lockdown }\end{array}$ \\
\hline \multicolumn{2}{|l|}{ No detail provided } \\
\hline Sanitize and distance & $\begin{array}{l}\text { Hand cleaning; } \\
\text { Social distancing }\end{array}$ \\
\hline No visitors, tradesman comply with current restrictions & $\begin{array}{l}\text { Only essential vis- } \\
\text { its/visitors }\end{array}$ \\
\hline $\begin{array}{l}\text { Hand sanitizer on all high touch areas. Spray disinfectant for } \\
\text { tools and barrows. Social distancing on the yard maintained. }\end{array}$ & $\begin{array}{l}\text { Hand cleaning; } \\
\text { Disinfection of } \\
\text { touchpoints; } \\
\text { Social distancing }\end{array}$ \\
\hline Only owners can come to the yard. & $\begin{array}{l}\text { Only essential vis- } \\
\text { its/visitors }\end{array}$ \\
\hline Social distancing of professional visitors, vet farrier etc. & Social distancing \\
\hline $\begin{array}{l}\text { Everyone allocated their own tools. No one to touch anyone } \\
\text { else's horse. Maintain } 2 \mathrm{~m} \text { distance at all time. Wash hands and } \\
\text { use sanitiser on arrival. }\end{array}$ & $\begin{array}{l}\text { Separate tools; } \\
\text { No touching of } \\
\text { horses by } \\
\text { strangers; } \\
\text { Social distancing; } \\
\text { Hand cleaning }\end{array}$ \\
\hline Disinfect all touch points. Keep 2 meter distance. Hand gel & $\begin{array}{l}\text { Disinfection of } \\
\text { touchpoints; } \\
\text { Social distancing; } \\
\text { Hand cleaning }\end{array}$ \\
\hline No new visitors only existing farrier, saddle fitter, vet etc & $\begin{array}{l}\text { Only essential vis- } \\
\text { its/visitors }\end{array}$ \\
\hline
\end{tabular}




\begin{tabular}{|c|c|}
\hline $\begin{array}{l}\text { Who ever visits has to have a mask on or keep a distance, we } \\
\text { have to have farrier, Saddle, Riding instructor, vet, and hay de- } \\
\text { livery all keep a distance }\end{array}$ & $\begin{array}{l}\text { Face mask; } \\
\text { Social distancing }\end{array}$ \\
\hline No one else comes to ride ponies (kids friends etc) & $\begin{array}{l}\text { Only essential vis- } \\
\text { its/visitors }\end{array}$ \\
\hline \multicolumn{2}{|l|}{ I followed BHS guidelines } \\
\hline No visitors. & $\begin{array}{l}\text { Complete yard } \\
\text { lockdown }\end{array}$ \\
\hline $\begin{array}{l}\text { We don't have staff, so my husband and I try to keep all non- } \\
\text { essential visits to an absolute minimum. }\end{array}$ & $\begin{array}{l}\text { Only essential vis- } \\
\text { its/visitors }\end{array}$ \\
\hline No visitors apart from support bubble and vet & $\begin{array}{l}\text { Only essential vis- } \\
\text { its/visitors }\end{array}$ \\
\hline \multicolumn{2}{|l|}{ No detail provided } \\
\hline Just keeping safe. Social distance and hand sanitiser used & $\begin{array}{l}\text { Social distancing; } \\
\text { Hand cleaning }\end{array}$ \\
\hline $\begin{array}{l}\text { Hand washing on arrival for essential visitors e.g. vet, farrier, } \\
\text { yard staff. Regular disinfectant wipes down of regularly } \\
\text { touched items eg doors, tools \& implements -at least at end of } \\
\text { every day Restricted access - essential staff only who must } \\
\text { inform me, preferably in advance if for any reason they have } \\
\text { to break COVID guidelines. Eg all individual Xmas plans were } \\
\text { discussed openly. Thus allowing isolation plans to be put in } \\
\text { place if necessary. }\end{array}$ & $\begin{array}{l}\text { Hand cleaning; } \\
\text { Disinfect touch- } \\
\text { points; } \\
\text { Only essential vis- } \\
\text { its/visitors; } \\
\text { Isolate if contract } \\
\text { COVID, or in con- } \\
\text { tact with someone } \\
\text { with COVID }\end{array}$ \\
\hline \multicolumn{2}{|l|}{ Obey gov guidelines } \\
\hline \multicolumn{2}{|l|}{ No detail provided } \\
\hline $\begin{array}{l}\text { Staff must wear gloves whilst working and we have reduced } \\
\text { down to one member of staff while the lockdown is ongoing to } \\
\text { reduce exposure. We also have } 2 \text { retirement livery which own- } \\
\text { ers are not able to visit during lockdown }\end{array}$ & $\begin{array}{l}\text { Gloves; } \\
\text { No owner visits }\end{array}$ \\
\hline Space face and hands - no one in my kitchen at the moment & $\begin{array}{l}\text { Social distancing; } \\
\text { Face mask; } \\
\text { Hand cleaning }\end{array}$ \\
\hline Social distancing between owner and jockeys' families & Social distancing \\
\hline \multicolumn{2}{|l|}{ No detail provided } \\
\hline $\begin{array}{l}\text { Same bubbles only, different times for people to come. Hand } \\
\text { sanitiser to be used when entering building social distancing } \\
\text { implemented }\end{array}$ & $\begin{array}{l}\text { Bubbles; } \\
\text { Visit scheduling; } \\
\text { Hand cleaning; } \\
\text { Social distancing }\end{array}$ \\
\hline Social distancing, masks, hand sanitizer, & $\begin{array}{l}\text { Social distancing; } \\
\text { Face mask; }\end{array}$ \\
\hline
\end{tabular}




\begin{tabular}{|c|c|}
\hline & Hand cleaning \\
\hline $\begin{array}{l}\text { Social distancing practiced all time. Surfaces and tools disin- } \\
\text { fected when leaving and entering yard. Hand washing with an- } \\
\text { tibacterial soap. Disposable cups only for any drinks Only } \\
\text { riding with one other person. No one else on yard other that } \\
\text { horse owners / immediate family and then only if no one else } \\
\text { on yard at same time. Staggering times where possible } \\
\text { Isolation periods horse care covered so no breaking of isola- } \\
\text { tion for respective horse owner; }\end{array}$ & $\begin{array}{l}\text { Social distancing; } \\
\text { Disinfection of } \\
\text { touchpoints; } \\
\text { Hand washing; } \\
\text { Only essential vis- } \\
\text { its/visitors; } \\
\text { Visit scheduling; } \\
\text { Isolate if contract } \\
\text { COVID, or in con- } \\
\text { tact with someone } \\
\text { with COVID }\end{array}$ \\
\hline $\begin{array}{l}\text { Currently wear mask when inside the barn, hand sanitiser on } \\
\text { way in, no conglomerating in tack room or other areas, only be } \\
\text { here to exercise attend to your horse. }\end{array}$ & $\begin{array}{l}\text { Face mask; } \\
\text { Hand cleaning; } \\
\text { Social distancing; } \\
\text { Only essential vis- } \\
\text { its/visitors }\end{array}$ \\
\hline Mask & Face mask \\
\hline I am the only user so basic hygiene and hand washing. & $\begin{array}{l}\text { Hand washing; } \\
\text { Complete yard } \\
\text { lockdown }\end{array}$ \\
\hline Groom stayed $2 m$ away & Social distancing \\
\hline Only me and boyfriend at yard/field. No visitors & $\begin{array}{l}\text { Complete yard } \\
\text { lockdown }\end{array}$ \\
\hline Hand sanitiser. $2 \mathrm{~m}$ distancing & $\begin{array}{l}\text { Hand washing; } \\
\text { Social distancing }\end{array}$ \\
\hline $\begin{array}{l}\text { Social distancing at all times - only being on the yard in order } \\
\text { to look after and exercise my horse. }\end{array}$ & $\begin{array}{l}\text { Social distancing; } \\
\text { Only essential vis- } \\
\text { its/visitors }\end{array}$ \\
\hline $\begin{array}{l}\text { It's only me there most days but } 1 \text { rider at a time to ride out } \\
\text { with me. We have } 5 \text { riders who loan my horses and all come } \\
\text { separately. }\end{array}$ & $\begin{array}{l}\text { Social distancing; } \\
\text { Visit scheduling }\end{array}$ \\
\hline $\begin{array}{l}\text { Social distancing with vet and farrier. Only other people on } \\
\text { yard are myself and my daughter }\end{array}$ & $\begin{array}{l}\text { Social distancing; } \\
\text { Only essential vis- } \\
\text { its/visitors }\end{array}$ \\
\hline Mask if vet or farrier come, otherwise no visiting. & $\begin{array}{l}\text { Face mask; } \\
\text { Only essential vis- } \\
\text { its/visitors }\end{array}$ \\
\hline No one to enter & $\begin{array}{l}\text { Complete yard } \\
\text { lockdown }\end{array}$ \\
\hline $\begin{array}{l}\text { Hands, face and space. First lockdown, yard closed to liveries. } \\
\text { Now in Tier 4, liveries allowed as part of daily exercise or for }\end{array}$ & $\begin{array}{l}\text { Face mask; } \\
\text { Social distancing; }\end{array}$ \\
\hline
\end{tabular}




\begin{tabular}{|c|c|}
\hline $\begin{array}{l}\text { animal welfare reasons. Liveries are all part or full, I.e. I do all } \\
\text { the care }\end{array}$ & $\begin{array}{l}\text { Hand cleaning; } \\
\text { Only essential vis- } \\
\text { its/visitors }\end{array}$ \\
\hline $\begin{array}{l}\text { No sharing equipment. Staggered visits so avoid others. Wash } \\
\text { hands regularly. }\end{array}$ & $\begin{array}{l}\text { Separate tools; } \\
\text { Visit scheduling; } \\
\text { Hand cleaning }\end{array}$ \\
\hline $\begin{array}{l}\text { I also have } 2 \text { cobs that are owned by and used for RDA Car- } \\
\text { riage driving. Their daily care is done by a small group of RDA } \\
\text { volunteers who come each day once a week so there are rules } \\
\text { to protect me and them. Hand sanitiser. } 2 \mathrm{~m} \text { distance. Wear } \\
\text { gloves. Separate barrows and forks. Sanitise anything they } \\
\text { have touched before they leave. }\end{array}$ & $\begin{array}{l}\text { Hand cleaning; } \\
\text { Social distancing; } \\
\text { Gloves; } \\
\text { Separate tools; } \\
\text { Disinfection of } \\
\text { touchpoints }\end{array}$ \\
\hline $\begin{array}{l}\text { I don't let anyone in other than vet, farrier etc they then wear } \\
\text { masks and sanitize hands etc. }\end{array}$ & $\begin{array}{l}\text { Only essential vis- } \\
\text { its/visitors; } \\
\text { Face mask; } \\
\text { Hand cleaning }\end{array}$ \\
\hline $\begin{array}{l}\text { Social distance. As little contact with other liveries where pos- } \\
\text { sible. Wash hands before and after visiting the yard }\end{array}$ & $\begin{array}{l}\text { Social distancing; } \\
\text { Hand cleaning }\end{array}$ \\
\hline Giving each other space & Social distancing \\
\hline Hands. Space & $\begin{array}{l}\text { Hand cleaning; } \\
\text { Social distancing }\end{array}$ \\
\hline $\begin{array}{l}2 m \text { rule, no gathering on the yard, no more than } 2 \text { on the yard } \\
\text { at one time. }\end{array}$ & $\begin{array}{l}\text { Social distancing; } \\
\text { Visit scheduling }\end{array}$ \\
\hline $\begin{array}{l}\text { No visitors to the yard and only our horses exercised together - } \\
\text { no mixing. }\end{array}$ & $\begin{array}{l}\text { Complete yard } \\
\text { lockdown }\end{array}$ \\
\hline No mixing of households & $\begin{array}{l}\text { Complete yard } \\
\text { lockdown }\end{array}$ \\
\hline Always wear gloves and wash your hands well afterwards & $\begin{array}{l}\text { Gloves; } \\
\text { Hand cleaning }\end{array}$ \\
\hline $\begin{array}{l}\text { Wash hands before starting anything on the yard. Sanitize } \\
\text { equipment after use and stable door latches. Social distancing. }\end{array}$ & $\begin{array}{l}\text { Hand cleaning; } \\
\text { Disinfection of } \\
\text { touchpoints; } \\
\text { Social distancing }\end{array}$ \\
\hline No visitors at all unless it's an emergency & $\begin{array}{l}\text { Only essential vis- } \\
\text { its/visitors; }\end{array}$ \\
\hline $\begin{array}{l}\text { We share a yard so all agree to disinfect whenever we enter or } \\
\text { leave the shared facilities }\end{array}$ & $\begin{array}{l}\text { Disinfection of } \\
\text { touchpoints }\end{array}$ \\
\hline $\begin{array}{l}\text { Staggering people down, all must sanitise on entry and spray } \\
\text { anything communal doors taps gates. During the first lock- } \\
\text { down no jumping or hacking. }\end{array}$ & $\begin{array}{l}\text { Visit scheduling; } \\
\text { Disinfection of } \\
\text { touchpoints; }\end{array}$ \\
\hline
\end{tabular}




\begin{tabular}{|c|c|}
\hline & $\begin{array}{l}\text { Basic riding/no rid- } \\
\text { ing }\end{array}$ \\
\hline $\begin{array}{l}\text { Anti bac daily touch points i.e., gates doors I do all feeding and } \\
\text { yard duties only me and my } 2 \text { daughters }\end{array}$ & $\begin{array}{l}\text { Disinfection of } \\
\text { touchpoints; } \\
\text { Only essential vis- } \\
\text { its/visitors }\end{array}$ \\
\hline Social distancing, bleaching of any surfaces/implements used & $\begin{array}{l}\text { Social distancing; } \\
\text { Disinfection of } \\
\text { touchpoints }\end{array}$ \\
\hline $\begin{array}{l}\text { No sharing of my equipment or tools. Sanitisers. Social distanc- } \\
\text { ing }\end{array}$ & $\begin{array}{l}\text { Separate tools; } \\
\text { Hand cleaning; } \\
\text { Social distancing }\end{array}$ \\
\hline $\begin{array}{l}\text { I am on my own at my yard... Just my ponies there. Nobody } \\
\text { else comes down there. }\end{array}$ & $\begin{array}{l}\text { Complete yard } \\
\text { lockdown }\end{array}$ \\
\hline Only visitors are equine related. Hay delivery, farrier, vet etc... & $\begin{array}{l}\text { Only essential vis- } \\
\text { its/visitors }\end{array}$ \\
\hline $\begin{array}{l}\text { No outside visitors other than direct family members and } \\
\text { masks must be worn indoors. Riding without a mask is permit- } \\
\text { ted but have only had two people who do not live with me } \\
\text { come ride during pandemic. }\end{array}$ & $\begin{array}{l}\text { Only essential vis- } \\
\text { its/visitors; } \\
\text { Face mask; }\end{array}$ \\
\hline No outsiders are allowed to ride at my place during lockdown. & $\begin{array}{l}\text { Complete yard } \\
\text { lockdown }\end{array}$ \\
\hline No visitors, all people have to wear gloves and masks & $\begin{array}{l}\text { Complete yard } \\
\text { lockdown; } \\
\text { Gloves; } \\
\text { Face mask }\end{array}$ \\
\hline $\begin{array}{l}\text { Distancing, no more than } 4 \text { of us there. All equipment kept } \\
\text { separate }\end{array}$ & $\begin{array}{l}\text { Social distancing; } \\
\text { Separate tools; } \\
\text { Visit scheduling }\end{array}$ \\
\hline \multicolumn{2}{|l|}{ No detail provided } \\
\hline $\begin{array}{l}\text { No contact with other owners or horses unless in an emer- } \\
\text { gancy, all have set times, masks to be worn at all times, sani- } \\
\text { tiser to be used, }\end{array}$ & $\begin{array}{l}\text { Social distancing; } \\
\text { Visit scheduling; } \\
\text { Face mask; } \\
\text { Hand cleaning }\end{array}$ \\
\hline $\begin{array}{l}\text { Depended on the different stages we were at. Masks. Appoint- } \\
\text { ments only. No more then } 4 \text { in the arena. At times no riding al- } \\
\text { lowed. At times no entry to the barn }\end{array}$ & $\begin{array}{l}\text { Social distancing; } \\
\text { Visit scheduling; } \\
\text { Basic riding/no rid- } \\
\text { ing; } \\
\text { Yard facilities shut }\end{array}$ \\
\hline $\begin{array}{l}\text { It's my home and I have two liveries on a rota with distancing } \\
\text { and sanitizer at all "touch" areas }\end{array}$ & $\begin{array}{l}\text { Social distancing; } \\
\text { Hand cleaning }\end{array}$ \\
\hline
\end{tabular}




\begin{tabular}{|c|c|}
\hline $\begin{array}{l}\text { For staff - Compulsory hand wash, sanitiser and medical gloves } \\
\text { to be used whilst on property plus QR code for NHS contact. }\end{array}$ & $\begin{array}{l}\text { Hand cleaning; } \\
\text { Gloves; } \\
\text { Track and trace } \\
\text { App }\end{array}$ \\
\hline $\begin{array}{l}\text { I am the yard owner. We have only } 2 \text { in the livery block at a } \\
\text { time. Luckily can divide yard into } 3 \text { different yards. I do ask } \\
\text { people to sanitise, coming in and out but generally I am not } \\
\text { sure people remember to do this. }\end{array}$ & $\begin{array}{l}\text { Hand cleaning; } \\
\text { Social distancing }\end{array}$ \\
\hline $\begin{array}{l}\text { The yard owner put in place a "no friends + family visitors" at } \\
\text { the start of the first lockdown, but this has gradually disap- } \\
\text { peared with no rules in place now. And they did nothing to } \\
\text { curtail the Fuddle that some people organised for Xmas. } \\
\text { set my "own rules" by keeping distant from others and avoid- } \\
\text { ing the tearoom whilst others are in sitting chatting in there } \\
\text { (even if it means I need to wee in my stable!). Lots of hand } \\
\text { sanitizer. }\end{array}$ & $\begin{array}{l}\text { Only essential vis- } \\
\text { its/visitors; } \\
\text { Social distancing; } \\
\text { Hand cleaning }\end{array}$ \\
\hline $\begin{array}{l}\text { Only me and family allowed on the yard (we own it, and only } \\
\text { our horses there) }\end{array}$ & $\begin{array}{l}\text { Complete yard } \\
\text { lockdown }\end{array}$ \\
\hline $\begin{array}{l}\text { I had been having building work done and all told not to go } \\
\text { near or touch horses }\end{array}$ & $\begin{array}{l}\text { No touching of } \\
\text { horses by strangers }\end{array}$ \\
\hline \multicolumn{2}{|l|}{ No detail provided } \\
\hline $\begin{array}{l}\text { Distance kept between myself and anyone who has to come to } \\
\text { administer to the horses }\end{array}$ & $\begin{array}{l}\text { Only essential vis- } \\
\text { its/visitors; } \\
\text { Social distancing }\end{array}$ \\
\hline $\begin{array}{l}\text { As there's only me and my daughter (and occasionally my son) } \\
\text { from the same household generally we just carry on as usual, } \\
\text { although we are more careful around each other both at home } \\
\text { and on the yard when coughing/sneezing and discarding of tis- } \\
\text { sues etc. If one of us is ill, we do our best to disinfect tool han- } \\
\text { dles, taps, sinks and anywhere else we may touch to try and } \\
\text { keep from passing it to each other. When we have the far- } \\
\text { rier/vet, we have the horses in tied up and ready, open all } \\
\text { gateways/doors so they don't need to touch anywhere, and } \\
\text { wear face masks even though we are outside. If any of us } \\
\text { have covid symptoms we stay away from the yard until tested } \\
\text { negative, although if we both had symptoms we would have to } \\
\text { carry on together at the yard but would make sure all surfaces } \\
\text { touched/used were sprayed with disinfectant regularly. }\end{array}$ & $\begin{array}{l}\text { Disinfection of } \\
\text { touchpoints; } \\
\text { Only essential vis- } \\
\text { its/visitors; } \\
\text { Face mask; } \\
\text { Isolate if contract } \\
\text { COVID, or in con- } \\
\text { tact with someone } \\
\text { with COVID; }\end{array}$ \\
\hline $\begin{array}{l}\text { By myself and yard owner. Wash and sanitise on arrival } \\
\text { No more than } 2 \text { people per barn or when riding in school/ } \\
\text { hacking. Only welfare of horses visitors permitted. Only own- } \\
\text { ers permitted, others by request of help maybe needed but }\end{array}$ & $\begin{array}{l}\text { Hand cleaning; } \\
\text { Social distancing; } \\
\text { Visit scheduling; }\end{array}$ \\
\hline
\end{tabular}




\begin{tabular}{|l|l|}
\hline $\begin{array}{l}\text { will be booked in around a time other are not on yard. Use } \\
\text { only your tools and kit. Tea rooms on both yards closed }\end{array}$ & $\begin{array}{l}\text { Only essential vis- } \\
\text { its/visitors; } \\
\text { Separate tools; } \\
\text { Yard facilities shut }\end{array}$ \\
\hline $\begin{array}{l}\text { On our private yard (we have renters who have fields from us) } \\
\text { everyone must wear gloves in the communal areas, no mixing } \\
\text { of households and keep distance. This was hard to get one lot } \\
\text { of liveries to do so they ended up leaving. On the hunter yard } \\
\text { it was very much the same as above. }\end{array}$ & $\begin{array}{l}\text { Gloves; } \\
\text { Social distancing }\end{array}$ \\
\hline $\begin{array}{l}\text { My horses are at home in a self-contained field. } \\
\text { No outsiders or unnecessary visits }\end{array}$ & $\begin{array}{l}\text { Complete yard } \\
\text { lockdown }\end{array}$ \\
\hline No visitors & $\begin{array}{l}\text { Only essential vis- } \\
\text { its/visitors }\end{array}$ \\
\hline
\end{tabular}

Appendix D1: Rules breached by respondents who answered "No" when asked: "Are you complying with the COVID-19 rules when undertaking horse related activities.

\begin{tabular}{|l|l|}
\hline Respondent answer & $\begin{array}{l}\text { Categorisation of } \\
\text { answer }\end{array}$ \\
\hline $\begin{array}{l}\text { In the first lockdown the rules were stay at home, only leave } \\
\text { home for } 30 \text { minutes exercise etc. My ponies are in a rural } \\
\text { area, no one else enters the land so I spent whole days with }\end{array}$ & $\begin{array}{l}\text { Spending extended } \\
\text { time at yard }\end{array}$ \\
\hline
\end{tabular}




\begin{tabular}{|c|c|}
\hline $\begin{array}{l}\text { them, packed lunch and flasks, exploring the surrounding area } \\
\text { with my daughter. We never came into contact with other } \\
\text { people though, we just enjoyed watching nature, looking after } \\
\text { the ponies and being outdoors. }\end{array}$ & \\
\hline $\begin{array}{l}\text { No social distancing, hand washing and using shared equip- } \\
\text { ment. }\end{array}$ & $\begin{array}{l}\text { Not social distanc- } \\
\text { ing; } \\
\text { Not hand washing; } \\
\text { Used shared equip- } \\
\text { ment }\end{array}$ \\
\hline $\begin{array}{l}\text { Most the time, yes, but for example yesterday, I arrived to } \\
\text { find a staff member battling with the horses as someone else } \\
\text { had unrugged one of my geldings. In working together to get } \\
\text { the rug back on, we couldn't successfully maintain social dis- } \\
\text { tancing. Our farrier also comes into our tier } 4 \text { area, so he can } \\
\text { still do our horses feet. Any broken rules are with the horses } \\
\text { welfare in mind. }\end{array}$ & $\begin{array}{l}\text { Not social distanc- } \\
\text { ing; }\end{array}$ \\
\hline $\begin{array}{l}\text { Not wearing a mask when in an indoor environment - e.g. tea } \\
\text { room or tack room. Not socially distancing at all times as it is } \\
\text { not possible to. Technically households mix as everyone } \\
\text { comes down before or after work at roughly the same times. }\end{array}$ & $\begin{array}{l}\text { Not wearing a } \\
\text { mask; } \\
\text { Not social distanc- } \\
\text { ing } \\
\text { Household mixing }\end{array}$ \\
\hline Social distancing with some people. & $\begin{array}{l}\text { Not socially dis- } \\
\text { tancing }\end{array}$ \\
\hline $\begin{array}{l}\text { No ones is ever about in the yard at the same time if there is } \\
\text { we keep two metres apart. }\end{array}$ & $\begin{array}{l}\text { No official rules as } \\
\text { owner does not } \\
\text { feel they are nec- } \\
\text { essary }\end{array}$ \\
\hline I don't need to, it's only me. & $\begin{array}{l}\text { No official rules as } \\
\text { owner does not } \\
\text { feel they are nec- } \\
\text { essary }\end{array}$ \\
\hline Don't read the rules so don't know. & $\begin{array}{l}\text { No official rules as } \\
\text { owner does not } \\
\text { feel they are nec- } \\
\text { essary }\end{array}$ \\
\hline $\begin{array}{l}\text { Generally, yes, apart from hacking- we will go out in a group } \\
\text { of three rather than a } 2 \text { and a single rider for safety. However, } \\
\text { we do maintain a greater than } 2 \mathrm{~m} \text { distance and don't mix with } \\
\text { anyone off the yard. }\end{array}$ & $\begin{array}{l}\text { Riding with others } \\
\text {-hacking }\end{array}$ \\
\hline My children continued to ride and have lessons at home & $\begin{array}{l}\text { Still exercising } \\
\text { horses; } \\
\text { Still having lessons }\end{array}$ \\
\hline
\end{tabular}




\begin{tabular}{|c|c|}
\hline $\begin{array}{l}\text { I'm in rural Ireland, I don't have much contact with other peo- } \\
\text { ple anyway. }\end{array}$ & $\begin{array}{l}\text { No official rules as } \\
\text { owner does not } \\
\text { feel they are nec- } \\
\text { essary }\end{array}$ \\
\hline Riding out with people. & $\begin{array}{l}\text { Riding with others } \\
\text {-hacking }\end{array}$ \\
\hline $\begin{array}{l}\text { Went on hacks with more than one other person on occasions } \\
\text { during the November lockdown but we were socially dis- } \\
\text { tanced. }\end{array}$ & $\begin{array}{l}\text { Riding with others } \\
\text { - hacking }\end{array}$ \\
\hline $\begin{array}{l}\text { Generally, yes - when travelling to hack out, the other person/ } \\
\text { people would travel separately in their cars. Unfortunately, } \\
\text { we lost a horse due to colic and during this time we did not } \\
\text { adhere to social distancing. }\end{array}$ & $\begin{array}{l}\text { Not socially dis- } \\
\text { tancing; } \\
\text { Riding with others } \\
\text { - hacking }\end{array}$ \\
\hline $\begin{array}{l}\text { At sometimes cannot socially distance with treating profes- } \\
\text { sionals etc due to safety/need to hold horse. Do wear mask if } \\
\text { less than } 2 \mathrm{~m} \text { from others. }\end{array}$ & $\begin{array}{l}\text { Not socially dis- } \\
\text { tancing; }\end{array}$ \\
\hline $\begin{array}{l}\text { Not wearing a mask due to open air of stables (and there's } \\
\text { probably worse stuff than COVID in the rafters) }\end{array}$ & $\begin{array}{l}\text { Not wearing a } \\
\text { mask }\end{array}$ \\
\hline \multirow[t]{2}{*}{ It's impossible you get on with it or the horse will suffer. } & $\begin{array}{l}\text { No official rules as } \\
\text { owner does not } \\
\text { feel they are nec- } \\
\text { essary }\end{array}$ \\
\hline & No details \\
\hline $\begin{array}{l}\text { Using my own judgement. Hacking in groups and caring for } \\
\text { others horses who I know are healthy. }\end{array}$ & $\begin{array}{l}\text { Riding with others } \\
\text { - hacking; } \\
\text { Caring for other } \\
\text { peoples horses }\end{array}$ \\
\hline Not social distancing like I should as outside. & $\begin{array}{l}\text { Not socially dis- } \\
\text { tancing }\end{array}$ \\
\hline $\begin{array}{l}\text { Not aware of any rules to do with covid and horses. I still go } \\
\text { and feed them etc and I stay away from people. I offered to } \\
\text { wear a mask when vet came she said I didn't need to }\end{array}$ & $\begin{array}{l}\text { No official rules as } \\
\text { owner does not } \\
\text { feel they are nec- } \\
\text { essary }\end{array}$ \\
\hline $\begin{array}{l}\text { Sometimes forget to keep } 2 \text { metre distance when filling hay } \\
\text { nets etc }\end{array}$ & $\begin{array}{l}\text { Not social distanc- } \\
\text { ing }\end{array}$ \\
\hline $\begin{array}{l}\text { I am complying with the rules but sometimes borrow others } \\
\text { equipment or bring their horses in. I sanitise before and after } \\
\text { so this should be safe. }\end{array}$ & $\begin{array}{l}\text { Sharing equip- } \\
\text { ment; } \\
\text { Caring for other } \\
\text { peoples horses }\end{array}$ \\
\hline I'm leaving home when I'm supposed to stay at home! & $\begin{array}{l}\text { Going to yard in } \\
\text { lockdown }\end{array}$ \\
\hline
\end{tabular}




\begin{tabular}{|c|c|}
\hline The horses are at home. No rules & $\begin{array}{l}\text { No official rules as } \\
\text { owner does not } \\
\text { feel they are nec- } \\
\text { essary }\end{array}$ \\
\hline $\begin{array}{l}\text { I am unsure of the rules with regards to exercising horses, but } \\
\text { I have continued as usual exercising my horses as safe as I } \\
\text { possibly can depending on the situation that presents me on } \\
\text { the day. }\end{array}$ & $\begin{array}{l}\text { Still exercising } \\
\text { horses }\end{array}$ \\
\hline $\begin{array}{l}\text { No direct hand washing as no facilities as do not want to con- } \\
\text { taminate horse's drinking water. Using hand gel and anti bac- } \\
\text { terial wipes instead. }\end{array}$ & No handwashing \\
\hline $\begin{array}{l}\text { Social distancing, masks. We tried during first lockdown and it } \\
\text { just didn't work at all. The yard is very much a diy yard and } \\
\text { rundown with a lot of stallions. Things break all the time, } \\
\text { horses get out and it was impossible to adhere to distancing } \\
\text { whilst repairing or retrieving. A number of us have health is- } \\
\text { sues as well which makes us extremely clinically vulnerable. } \\
\text { However, most of us there are only seeing yard people and no } \\
\text { one else after leaving }\end{array}$ & $\begin{array}{l}\text { Not social distanc- } \\
\text { ing; } \\
\text { Not wearing face } \\
\text { mask }\end{array}$ \\
\hline $\begin{array}{l}\text { Not keeping } 2 \text { meter distance from other liveries. Spending } \\
\text { more time than I probably should at the yard. }\end{array}$ & $\begin{array}{l}\text { Not social distanc- } \\
\text { ing; } \\
\text { Spending extended } \\
\text { times at the yard }\end{array}$ \\
\hline $\begin{array}{l}\text { Not wearing a mask in my stable due to hard to breathe. No } \\
\text { gloves when grooming or turning out/bringing in. }\end{array}$ & $\begin{array}{l}\text { Not wearing face } \\
\text { mask; } \\
\text { Not wearing gloves }\end{array}$ \\
\hline \multirow[t]{2}{*}{ Still holding group lessons } & $\begin{array}{l}\text { Still having lessons; } \\
\text { Riding with others } \\
\text { - Arena }\end{array}$ \\
\hline & No details \\
\hline $\begin{array}{l}\text { Riding in groups of } 3 \text { (rather than } 2 \text { ) safer to ride in a bigger } \\
\text { group of } 3 \text { in case someone falls off- one person to stay with } \\
\text { person injured and the other to get help. }\end{array}$ & $\begin{array}{l}\text { Riding with others } \\
\text { - hacking }\end{array}$ \\
\hline $\begin{array}{l}\text { I attend to my horse twice, you pay more than enough a } \\
\text { month ( } 5 \text { day livery) without extra services to pay for. }\end{array}$ & $\begin{array}{l}\text { Spending extended } \\
\text { time at yard; }\end{array}$ \\
\hline $\begin{array}{l}\text { We try to go to the yard when no one else is there but it's dif- } \\
\text { ficult because of people's work commitments. There are only } \\
\text { three owners though. We try to only use our own equipment } \\
\text { but are feeding and turning out all the horses. We use sani- } \\
\text { tiser upon entry to the yard and upon leaving. If new symp- } \\
\text { toms occur, I have had a test and had results back within } \\
\text { 24hours. So far, my tests have been negative so this hasn't }\end{array}$ & $\begin{array}{l}\text { Caring for other } \\
\text { people's horses }\end{array}$ \\
\hline
\end{tabular}




\begin{tabular}{|c|c|}
\hline $\begin{array}{l}\text { proved a problem, otherwise others would look after my po- } \\
\text { nies. }\end{array}$ & \\
\hline Not left home with horses since start of pandemic & No details \\
\hline $\begin{array}{l}\text { I have my horses on a very busy livery yard - it's not always } \\
\text { possible to stay } 2 \mathrm{~m} \text { away from others. Also not always able to } \\
\text { ride in the arena by myself - usually others. }\end{array}$ & $\begin{array}{l}\text { Not socially dis- } \\
\text { tancing; } \\
\text { Riding with others } \\
\text { - Arena }\end{array}$ \\
\hline Spending most of day at yard. Riding out with others. & $\begin{array}{l}\text { Spending extended } \\
\text { time at yard; } \\
\text { Riding with others } \\
\text { - Hacking }\end{array}$ \\
\hline \multirow[t]{2}{*}{$\begin{array}{l}\text { We have travelled to arenas/hired places and travelled to- } \\
\text { gether with other people. Also ridden in groups. }\end{array}$} & $\begin{array}{l}\text { Riding with others } \\
\text { - Arena } \\
\text { Not social distanc- } \\
\text { ing }\end{array}$ \\
\hline & No details \\
\hline $\begin{array}{l}\text { My horse is kept in a neighbouring town that is in a different } \\
\text { Tier. I am in Tier } 3 \text { and horse is in Tier } 4 \text {, so technically I am } \\
\text { not sure if I can travel to pick my horse up, and take to com- } \\
\text { petitions in Tier } 3 \text { ?!? }\end{array}$ & $\begin{array}{l}\text { Moving between } \\
\text { tiers }\end{array}$ \\
\hline $\begin{array}{l}\text { I am moving between tiers as my yard is in a different tier. } \\
\text { Can't maintain social distancing due to small shared tack room } \\
\text { and other people not understanding how far } 2 \text { meters is }\end{array}$ & $\begin{array}{l}\text { Moving between } \\
\text { tiers; } \\
\text { Not social distanc- } \\
\text { ing }\end{array}$ \\
\hline $\begin{array}{l}\text { No need as horses are at home and only done by myself and } \\
\text { my daughter }\end{array}$ & $\begin{array}{l}\text { No official rules as } \\
\text { owner does not } \\
\text { feel they are nec- } \\
\text { essary }\end{array}$ \\
\hline $\begin{array}{l}\text { Large tack room is narrow and easy for people to stop and } \\
\text { chat put of the way. }\end{array}$ & $\begin{array}{l}\text { Not social distanc- } \\
\text { ing }\end{array}$ \\
\hline Travel to tier 4. & $\begin{array}{l}\text { Moving between } \\
\text { tiers }\end{array}$ \\
\hline Travelling to and from yard during lockdowns. & $\begin{array}{l}\text { Going to yard in } \\
\text { lockdown }\end{array}$ \\
\hline $\begin{array}{l}\text { Don't need to. I am totally on my own there so no contact } \\
\text { with anyone. }\end{array}$ & $\begin{array}{l}\text { No official rules as } \\
\text { owner does not } \\
\text { feel they are nec- } \\
\text { essary }\end{array}$ \\
\hline $\begin{array}{l}\text { Due to liveries work schedules it's impossible to have just } 1 \\
\text { person there at a time, it's busy around 7-8am before work } \\
\text { and after } 5 \text { when works finished. There's no other time in the } \\
\text { day to look after the horses and as such there could be as }\end{array}$ & $\begin{array}{l}\text { Not social distanc- } \\
\text { ing }\end{array}$ \\
\hline
\end{tabular}




\begin{tabular}{|c|c|}
\hline $\begin{array}{l}\text { many as } 8 \text { people there at a time, we try our best to distance } \\
\text { and not touch other people's belongings but it's hard when } \\
\text { horses share field space, hay/straw bales and a single tap. }\end{array}$ & \\
\hline Horses are at home, so I really don't have any "rules". & $\begin{array}{l}\text { No official rules as } \\
\text { owner does not } \\
\text { feel they are nec- } \\
\text { essary }\end{array}$ \\
\hline Would feel unsure whether to exercise horses. & $\begin{array}{l}\text { Still exercising } \\
\text { horse }\end{array}$ \\
\hline Everything! & $\begin{array}{l}\text { No official rules as } \\
\text { owner does not } \\
\text { feel they are nec- } \\
\text { essary }\end{array}$ \\
\hline I am just carrying on as normal. And will continue to do so. & $\begin{array}{l}\text { No official rules as } \\
\text { owner does not } \\
\text { feel they are nec- } \\
\text { essary }\end{array}$ \\
\hline $\begin{array}{l}\text { I am currently } 6 \text { months pregnant and a member of family } \\
\text { who I don't live with usually accompanies me on foot (regard- } \\
\text { less of lockdown conditions) for safety and reassurance - occa- } \\
\text { sional hacks approx. every week for up to an hour. }\end{array}$ & $\begin{array}{l}\text { Still exercising } \\
\text { horse }\end{array}$ \\
\hline $\begin{array}{l}\text { They are at home and only I see to them, nobody comes in or } \\
\text { out but me. }\end{array}$ & $\begin{array}{l}\text { No official rules as } \\
\text { owner does not } \\
\text { feel they are nec- } \\
\text { essary }\end{array}$ \\
\hline $\begin{array}{l}\text { For the first } 6 \text { months I was extremely careful, socially dis- } \\
\text { tanced and wore a mask in the presence of other equestrians } \\
\text { etc. I used to have them at home but moved to one yard on } \\
\text { full livery then moved across the country (from North West } \\
\text { Midlands to North East) and honestly we find it very challeng- } \\
\text { ing to socially distance and wear masks. Having } 4 \text { horses I'm } \\
\text { often there for } 2-3 \text { hours, in cold conditions my nose runs con- } \\
\text { stantly so cotton masks get soaked and the alternative is a J3 } \\
\text { respirator which is almost dangerous to wear around my } \\
\text { horses due to constantly getting hit in the face lol. E.g. around } \\
\text { the hay nets we are all filling from the same bale with } 80-90 \\
\text { horses on the yard so we are definitely closer than } 2 \text { m. At } \\
\text { Christmas time I hugged one of my friends, she was upset and } \\
\text { crying. At the end of the day the distancing was taking such a } \\
\text { major toll on mental health. We have also started one of my } \\
\text { project horses together and probably come within } 2 \text { m then } \\
\text { too. Outside of the yard we adhere to all measures though so } \\
\text { one could say she's a part of my 'bubble'. }\end{array}$ & $\begin{array}{l}\text { Not social distanc- } \\
\text { ing; } \\
\text { Not wearing face } \\
\text { mask }\end{array}$ \\
\hline
\end{tabular}




\begin{tabular}{|c|c|}
\hline $\begin{array}{l}\text { I maintain where I can but if someone is having an issue with } \\
\text { their horse I go and help. Especially if hacking and we've had } \\
\text { someone in our group fall recently. Sometimes when } \\
\text { mucking out we pass each other quickly as there is not much } \\
\text { room between boxes to distance when we're getting jobs } \\
\text { done at busy periods (usually after work } 5 \mathrm{pm} \text { to } 7 \mathrm{pm} \text { ). }\end{array}$ & $\begin{array}{l}\text { Not social distanc- } \\
\text { ing }\end{array}$ \\
\hline $\begin{array}{l}\text { I ride with a few people that aren't in my bubble and we don't } \\
\text { social distance. }\end{array}$ & $\begin{array}{l}\text { Not social distanc- } \\
\text { ing; } \\
\text { Riding with others } \\
\text { - Hacking }\end{array}$ \\
\hline $\begin{array}{l}\text { Have youngsters so too dangerous to ride out alone so riding } \\
\text { out with others. Also freezing cold so meet up at my friends } \\
\text { house to warm up etc. }\end{array}$ & $\begin{array}{l}\text { Riding with others } \\
\text { - Hacking; } \\
\text { Not social distanc- } \\
\text { ing }\end{array}$ \\
\hline $\begin{array}{l}\text { I occasionally forget to socially distance when I'm talking to } \\
\text { other liveries. }\end{array}$ & $\begin{array}{l}\text { Not social distanc- } \\
\text { ing }\end{array}$ \\
\hline $\begin{array}{l}\text { Isolating after test today \& still have to go check on horses \& } \\
\text { give hay. }\end{array}$ & $\begin{array}{l}\text { Not isolating when } \\
\text { should be }\end{array}$ \\
\hline $\begin{array}{l}\text { I've shared the arena with others at times of lockdown. This is } \\
\text { in a } 60 \times 40 \text { area so feel this is much safer than say going to } \\
\text { the gym / supermarket etc. }\end{array}$ & $\begin{array}{l}\text { Riding with others } \\
\text { - Arena }\end{array}$ \\
\hline $\begin{array}{l}\text { Not using sanitizers or face masks and not reducing numbers } \\
\text { attending. }\end{array}$ & $\begin{array}{l}\text { Not hand cleaning; } \\
\text { Not socially dis- } \\
\text { tancing; } \\
\text { Not wearing face } \\
\text { mask }\end{array}$ \\
\hline $\begin{array}{l}\text { It's hard to say whether we are really complying or not. We } \\
\text { are a small yard, with only a yard owner, groom and perhaps } \\
8 / 9 \text { liveries /loaners. When at the yard we keep ourselves to } \\
\text { ourselves aside from lessons, but there may be } 4 \text { or } 5 \text { people } \\
\text { on the yard at the same time. We are maintaining social dis- } \\
\text { tancing in the main (e.g. unless holding a horse so someone } \\
\text { can mount safely) }\end{array}$ & $\begin{array}{l}\text { Not socially dis- } \\
\text { tancing }\end{array}$ \\
\hline $\begin{array}{l}\text { Mixing with more than } 1 \text { person while on yard doing stable } \\
\text { duties etc. }\end{array}$ & $\begin{array}{l}\text { Not socially dis- } \\
\text { tancing }\end{array}$ \\
\hline \multirow[t]{2}{*}{ I ride out on my own. } & $\begin{array}{l}\text { Still exercising } \\
\text { horse }\end{array}$ \\
\hline & No response \\
\hline $\begin{array}{l}\text { What is compiling? ;-) I jest... yes, we comply with any } \\
\text { Covid restriction rules where we are aware of them BUT at no } \\
\text { time would we compromise our horses' care because of them! }\end{array}$ & $\begin{array}{l}\text { Not when welfare } \\
\text { reasons dictate }\end{array}$ \\
\hline
\end{tabular}




\begin{tabular}{|c|c|}
\hline What are rules horses don't have Covid. & $\begin{array}{l}\text { No official rules as } \\
\text { owner does not } \\
\text { feel they are nec- } \\
\text { essary }\end{array}$ \\
\hline $\begin{array}{l}\text { You are not meant to travel to exercise; however I travel to } \\
\text { my yard to tend to my horse and ride while there. }\end{array}$ & $\begin{array}{l}\text { Going to yard in } \\
\text { lockdown; } \\
\text { Still exercising } \\
\text { horse }\end{array}$ \\
\hline $\begin{array}{l}\text { Not wearing masks in the barn, no number limited on the in- } \\
\text { door arena when riding, minimal to no social distancing on the } \\
\text { yard when doing jobs }\end{array}$ & $\begin{array}{l}\text { Not wearing mask; } \\
\text { Not socially dis- } \\
\text { tancing; } \\
\text { Riding with others } \\
\text { - Arena }\end{array}$ \\
\hline \multirow[t]{2}{*}{$\begin{array}{l}\text { I try hard to follow the rules, but did call via the yard on the } \\
\text { way back from } 2 \text { week holiday in France in the summer before } \\
\text { staying at home for } 14 \text { days quarantine. I didn't want to go a } \\
\text { full month without saying hello to my horse, and wanted to } \\
\text { check feed supplies. I stayed at least } 20 \mathrm{~m} \text { away from anyone } \\
\text { and was only there } 5 \text { or } 10 \text { mins. }\end{array}$} & $\begin{array}{l}\text { Not isolating when } \\
\text { should be }\end{array}$ \\
\hline & No response \\
\hline $\begin{array}{l}\text { I hack out with one other person not in my support bubble. I } \\
\text { feel this is safer than hacking alone. Other than that, I am very } \\
\text { careful and follow all other rules. }\end{array}$ & $\begin{array}{l}\text { Riding with others } \\
\text { - Hacking }\end{array}$ \\
\hline $\begin{array}{l}\text { I'm not sure. I'm leaving home and driving } 4 \text { miles to the } \\
\text { field every day. Then I'm taking the horse out of the field to go } \\
\text { for a ride several times a week. So technically I'm driving } \\
\text { somewhere to do exercise. Also the field is in the next } \\
\text { county, Flintshire, so I'm crossing the border. BUT driving to } \\
\text { the field is necessary for animal welfare and my own sanity. } \\
\text { Plus as the field is in a fairly remote rural area I don't actually } \\
\text { have any contact with any other people when I go. Just the oc- } \\
\text { casional walker or cyclist on the lane. So I may be breaking } \\
\text { the letter of the rules but not the spirit as I'm not in any con- } \\
\text { tact with anyone. }\end{array}$ & $\begin{array}{l}\text { Going to yard in } \\
\text { lockdown }\end{array}$ \\
\hline $\begin{array}{l}\text { During the lockdown was out with horses riding \& doing jobs } \\
\text { for more than } 1 \text { hour }\end{array}$ & $\begin{array}{l}\text { Spending extended } \\
\text { time at yard; } \\
\text { Still exercising } \\
\text { horse }\end{array}$ \\
\hline
\end{tabular}


Appendix E1: Rules breached by respondents answering "No" when asked: "Are you complying to COVID-19 rules when not undertaking horse related activities". 8 respondents did not answer the question.

\begin{tabular}{|l|l|}
\hline Respondent answer & $\begin{array}{l}\text { Categorisation of an- } \\
\text { swer }\end{array}$ \\
\hline $\begin{array}{l}\text { I still go and see my parents as my dad has dementia and } \\
\text { is going downhill fast. I am very careful everywhere else } \\
\text { though. }\end{array}$ & $\begin{array}{l}\text { Seeing family members } \\
\text { not in same household }\end{array}$ \\
\hline Still seeing parents. & $\begin{array}{l}\text { Seeing family members } \\
\text { not in same household }\end{array}$ \\
\hline
\end{tabular}




\begin{tabular}{|c|c|}
\hline & No response \\
\hline & No response \\
\hline $\begin{array}{l}\text { I take longer than } 30 \text { minutes for exercise - usually an } \\
\text { hour in morning \& half hour in evening to walk my dogs } \\
\text { \& self-exercise. I have also met up with my son on several } \\
\text { occasions when we shouldn't have but he was living } \\
\text { alone, working from home and had slight depression due } \\
\text { to his father passing the year before - I felt it necessary } \\
\text { for his mental health to still see him. }\end{array}$ & $\begin{array}{l}\text { Seeing family members } \\
\text { not in same household }\end{array}$ \\
\hline $\begin{array}{l}\text { Socialising with a small group of friends, who I see at } \\
\text { work any way so it's not really increasing risk to me. }\end{array}$ & $\begin{array}{l}\text { Seeing friends not in the } \\
\text { same household }\end{array}$ \\
\hline I'm leaving home to walk and train my 5 working dogs & Leaving home \\
\hline Don't wear a mask. & Not wearing a mask \\
\hline \multirow[t]{2}{*}{$\begin{array}{l}\text { Same reasons as stated previously, time schedules and } \\
\text { sharing of resources make it hard to keep a strong dis- } \\
\text { tance. }\end{array}$} & Not social distancing \\
\hline & No response \\
\hline I'm not following any of the guidance set by government. & Not following any rules \\
\hline $\begin{array}{l}\text { I work in a food supermarket and people don't social dis- } \\
\text { tance from me. }\end{array}$ & Not social distancing \\
\hline $\begin{array}{l}\text { I still have visitors if they want to come and we do not al- } \\
\text { ways socially distance however I am on my own private } \\
\text { yard so there is not much interaction anyway, outside my } \\
\text { household. }\end{array}$ & $\begin{array}{l}\text { Seeing friends not in the } \\
\text { same household; } \\
\text { Not social distancing }\end{array}$ \\
\hline $\begin{array}{l}\text { Have met up with parents on several occasions and also } \\
\text { two close friends who live very near us. One of which is a } \\
\text { medical professional and regularly covid tested. My } \\
\text { parents had to look after me/ferry me around as I re- } \\
\text { cently broke my foot and couldn't drive and got very } \\
\text { lonely at home when my husband was working. Our } \\
\text { friends are for our mental health. They are understanding } \\
\text { and always offer an ear when needed. }\end{array}$ & $\begin{array}{l}\text { Seeing family members } \\
\text { not in same household; } \\
\text { Seeing friends not in the } \\
\text { same household }\end{array}$ \\
\hline $\begin{array}{l}\text { We have travelled abroad having followed the rules reli- } \\
\text { giously for nine months. Not against the law but it was } \\
\text { not essential. }\end{array}$ & Travelled abroad \\
\hline $\begin{array}{l}\text { I have walked the dog outside my immediate area as it is } \\
\text { on route home from my ponies who live } 30 \text { mins away. }\end{array}$ & Leaving home \\
\hline $\begin{array}{l}\text { Meeting up with friends \& family as my mental health } \\
\text { was suffering. Travelling in/out of tiers. }\end{array}$ & $\begin{array}{l}\text { Seeing friends not in the } \\
\text { same household; } \\
\text { Travelling between tiers }\end{array}$ \\
\hline $\begin{array}{l}\text { Sometimes a friend meets me at the horses and it's not a } \\
\text { public place. This was in lockdown and also in tier 3. It's }\end{array}$ & $\begin{array}{l}\text { Seeing friends not in the } \\
\text { same household }\end{array}$ \\
\hline
\end{tabular}




\begin{tabular}{|c|c|}
\hline $\begin{array}{l}\text { safer to have a person with me when I ride as my mare is } \\
\text { recently backed. She social distances and we are always } \\
\text { outside. }\end{array}$ & \\
\hline $\begin{array}{l}\text { I don't agree with any of it. I am not a prisoner. I won't } \\
\text { stand back and loose more people that can't cope with } \\
\text { the lock down. It is causing more deaths that covid. }\end{array}$ & Not following any rules \\
\hline $\begin{array}{l}\text { I'm a teacher so cannot do social distancing because the } \\
\text { pupils come too close, no matter how many times you } \\
\text { tell them. }\end{array}$ & Not social distancing \\
\hline $\begin{array}{l}\text { I am a student and currently back at school or going back } \\
\text { in a few days and we aren't social distancing but before } \\
\text { we go back if you are in year } 11-13 \text { (upper sixth) it is rec- } \\
\text { ommended to get a test before returning. }\end{array}$ & Not social distancing \\
\hline Seeing 2 households. & $\begin{array}{l}\text { Seeing friends not in the } \\
\text { same household }\end{array}$ \\
\hline Keeping larger bubbles than allowed. & $\begin{array}{l}\text { Seeing friends not in the } \\
\text { same household }\end{array}$ \\
\hline $\begin{array}{l}\text { Have seen friends in the garden a few times as we are fed } \\
\text { up. }\end{array}$ & $\begin{array}{l}\text { Seeing friends not in the } \\
\text { same household }\end{array}$ \\
\hline Have travelled to see my boyfriend in a different tier. & $\begin{array}{l}\text { Meeting up with family } \\
\text { members not in the } \\
\text { same household; } \\
\text { Travelling between tiers }\end{array}$ \\
\hline Travelling 3 miles for exercise. & Leaving home \\
\hline Wearing a mask as I get panic attacks. & Not wearing a mask \\
\hline Meeting with friends. & $\begin{array}{l}\text { Seeing friends not in the } \\
\text { same household }\end{array}$ \\
\hline $\begin{array}{l}\text { I have continued to have regular contact with my daugh- } \\
\text { ter and her husband and children. But I also provide } \\
\text { childcare for her while she works so I think I'm "legal" but } \\
\text { we don't care. We all live in a semi-rural area and have } \\
\text { minimal contact with other people. Other than that I } \\
\text { comply. I only go out to the shops, to her house, and to } \\
\text { the horses. I haven't seen my best friend for months, she } \\
\text { lives over the border in Cheshire. }\end{array}$ & $\begin{array}{l}\text { Meeting up with family } \\
\text { members not in the } \\
\text { same household }\end{array}$ \\
\hline $\begin{array}{l}\text { I have met up with more than one person for a dog walk. } \\
\text { But we all socially distanced. Its a ludicrous rule though - } \\
\text { it is exactly the same as dog walking with one person one } \\
\text { day and a different person the next }\end{array}$ & $\begin{array}{l}\text { Seeing friends not in the } \\
\text { same household }\end{array}$ \\
\hline
\end{tabular}

